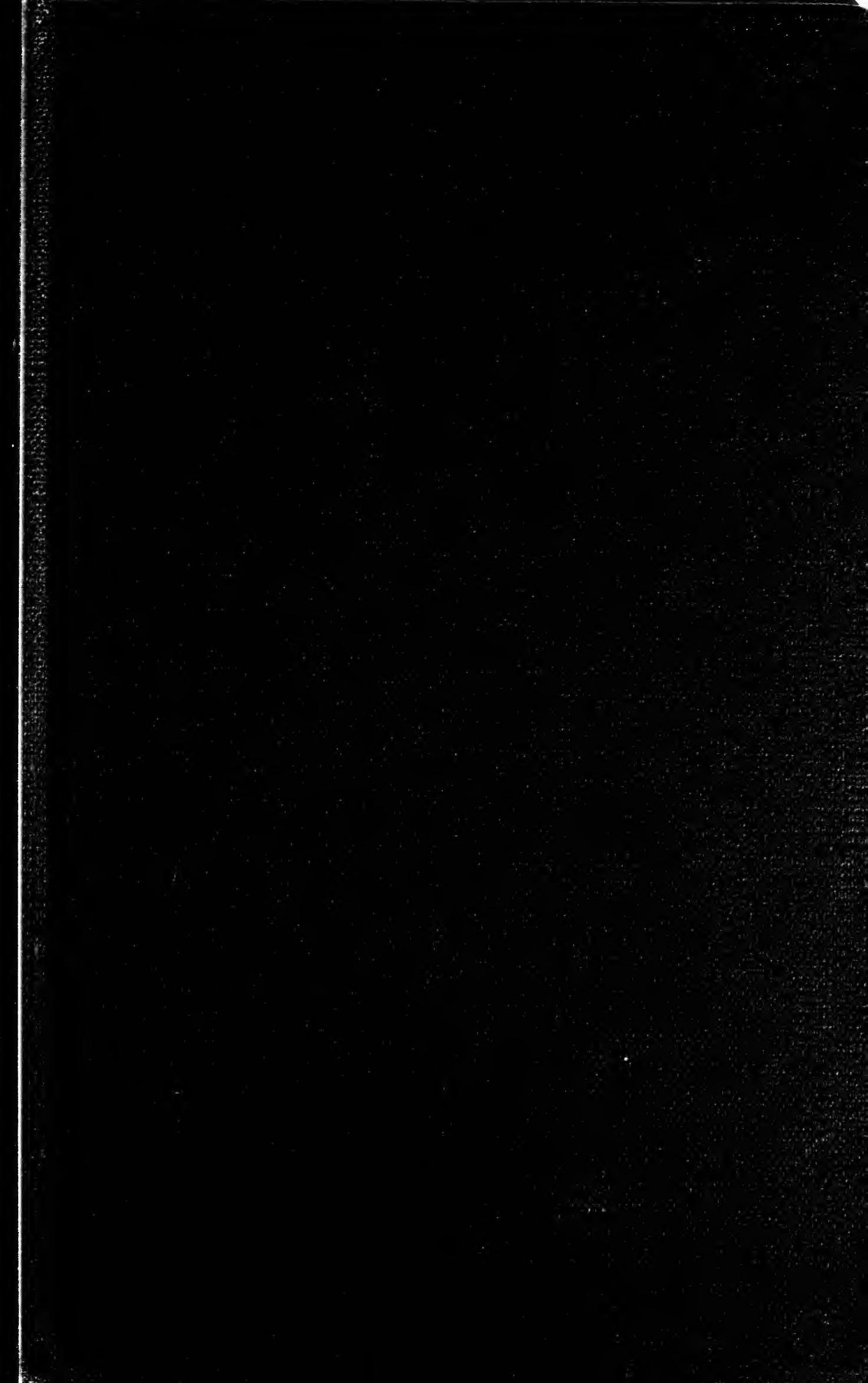









\title{
LETTERS
}

\author{
OF

\section{JOHN HAY}

AND

EXTRACTS FROM DIARY

Volume II

WASHINGTON

1908

Printed but not Publishen 
IN MESTO :

$F / P+\ldots . .1$.

Copyright, 1908, by Clara S. Hay

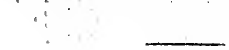

$\therefore \vdots \vdots$ 


\section{LETTERS}

\section{OF \\ JOHN HAY}

HAY TO NICOLAY.

Warsaw, Illinois.

October 13, 1870.

MY DEAR NICOLAY :

I have just received the enclosed from $\mathrm{W}-$. It is a model of holy and unselfish anger against foul and infamous outrage. I have written him a letter of cordial sympathy and you will doubtless do the same. The article he refers to, I wrote after you left $\mathrm{C} \longrightarrow$, for the $N . Y . T-$ I have not seen it.

I flitted on Tuesday after shipping my charming wards. I found Warsaw with a broad grin on its face at the lovely grape crop. My father made 1200 gallons of good wine, and even my shy little vineyard made its début with 240 . 
I wish you could have been here and eaten grapes with me during the past week. They are of a most exquisite flavor and sweeter than I have ever seen them anywhere in the world. Especially the much abused Catawba, which people were thinking of ploughing up, has nobly asserted itself and produced a superb vintage. We are now through, and ready for the frost when it comes.

The weather is lovely. The great river is wrapped at daybreak in a morning gown of fog, but soon brightens up, and the light has a regular spree on the many-colored foliage of the hills and the islands.

I am doing nothing and find it easy to take. I walk a great deal and eat for several. I have gained two pounds in weight the first week.

I have a very cordial letter from $\mathrm{H}-$ saying he thinks my decision the best one; that the publication in the Magazine will not hurt the book, but will be a positive advantage to it. So my mind is at rest on that score. 
HAY TO WHITELAW REID.

Washington, December, 1870.

MY DEAR REID :

Here is a sketchy letter with nothing in itwhich you can use or kill.

I have had no chance for any decent work. I wrote no account of the wedding ${ }^{1}$ because the family assumed to be dead agin it,-Mrs. S Pres having spoken with some severity of $\mathrm{H}$. J. $\mathrm{Q}$ - for having taken notes. I do not do these things, but would have gushed if you had especially wished it. I gave Mr. W- the points the night before.

I found Mrs. S— had accepted for me, invitations for Friday and Saturday, so that instead of being with you Saturday night I shall not report until Monday morning.

So many people have spoken of you and sent greetings that my paper would not hold their names. The Chief Justice and the ladies were sorry not to see you. He said the Great Moral Organ had improved enormously under your management and was now easily at the head of

${ }^{1}$ The wedding of Miss Chase to Mr. William Hoyt. 
the dailies. S- also spoke of the excellence of the paper.

In a street car the other night I met Z$\mathrm{C}$ - He says $\mathrm{G}-$ is all right-he hopes you are all right. He knows $I$ am all right (interrogatively). He says the $T$ - must support the Administration and not get switched off. Asks if it will do any good for him to go up to New York and talk to you, and H. G-. I said, "No! write! Your name and vigorous style would have as much effect as your personal presence."

I am between Celery and Cherubs. I dine with S_ Sunday.

I will take your orders when I get back as to whether I shall write an $\mathrm{R}$ - article or do up P-_'s. The statue is worse than I expected.

HAY TO NICOLAY.

New York Tribune.

MY DEAR NICOLAY :

December 12, 1870.

I have delayed writing for a few days, knowing you had seen $\mathrm{R} \longrightarrow$, and that he had told you I 
was alive. I am living at the $\mathrm{A}-$ House which is now run on the European plan, and gives me a room on rather reasonable terms. I am working daily on the $T$ - writing editorials, or as it is here technically called, brevier. I get salary enough to pay my board and washing.

I cannot regard it as a successful experiment as yet, though $\mathrm{R}$ - and the rest seem satisfied. I do not find myself up to the work of writing so much every day on a given theme. But the $T$ - force is sufficient to allow a good deal of subdivision, and so far I have written just what I please.

That ridiculous rhyme Little Breeches of mine has had a ridiculous run. It has been published in nearly the whole country press from here to the Rocky Mountains. As my initials are not known and they generally get worn off on the second print, I have not been disgraced by it.

I met G — at breakfast this morning, who called me Nicolay and was very cordial. That reminds me of Madrid, where we were all called $\mathrm{S}$ — by the Señoritas for a week or two.

$\mathrm{R}$ - talks of sending me to Washingtonnot as reporter, but as a sort of heavy-swell correspondent; whereat I rather reluct. I do not 
like to blame and I mortally hate to praise. Which somewhat narrows a letter writer's field.

Have you seen the first of my Castilian Dayswhich by a Hibernicism of $\mathrm{F}$-, is a night? He seems greatly pleased with the stuff I have given him, and proposes to make a book of it next year. I went on there and spent a day or two very pleasantly among the geistreich of Cambridge and the hub?

HAY TO HOWELLS.

Tribune Office, December 29, 1870.

MY DEAR HOWELLS :

I thank you cordially for your delicious book. I had a copy before and can now indulge in the luxury of giving it away. You are my delight and my despair. Where the demon did you find that impossibly happy way of saying everything? It is a thing that the rest of us blunder on, once in a while, but you never miss. It is no trick or fashion, and so we will never tire of it till we tire of living. You see the critics all notice this, and not knowing what else to say, they say Hawthorne and Irving, etc. . . . . 
I am plodding along, doing rather better than I expected. Have you ever seen a piece of dialect I wrote,-Little Breeches? It has had an appalling run. It is published every day in hundreds of papers. Two political papers in the west have issued illustrated editions of it. I mention this to show what a ravenous market there is for anything of the sort. I can't do it-but you could. That western novel of yours must not be much longer delayed.

When I said I can't, it was not measley but true. I wrote another one, and $\mathrm{R}$ - says it is very bad-in which I agree,-so it is not to be published and I will do no more songs. . . . .

HAY TO NICOLAY.

March, 1871.

MY DEAR NICOLAY :

.... Item. They send you the February Atlantic. The March No. has nothing from me, and therefore it won't pay to buy it. The April No. has a first-rate article on Spanish holidays by a youth to fortune and to fame unknown. Item. 
The March Lippincott, which has a Warsaw story into it.

I am rubbing along, doing my day's work daily-not entirely satisfied with myself but drawing my pay regular. The correct press and the unsuccessful critics pound me black and blue, but I eat my diurnal hash with a good appetite, and get more than is right for everything I do. I have just sold a third dialect poem to $\mathrm{H}$ $\mathrm{W}$ - for $\$ 50$ to be published with a picture. It is called Banty Jim and touches the contraband. Have you seen Jim Bludso? I send you a copy. It has been more widely liked and denounced than Little Breech.

Horrible power of drink! Last night I metat the $T$ - door-you know him, the wittiest journalist of our time. He was covered with mud and plastering, Had been rolling in the gutterwas crying like a sick child-said they had kicked him out of the last place he was in,--begged me for twenty cents, and sobbed with joy when I gave him fifty. Some night he will die in the street. You and I have kept drinking company all our lives, and yet have never felt for an instant the claws of temptation. Let us thank God! 
HAY TO ALBERT RHODES.

New York, June 19, 1871.

MY DEAR RHODES:

I am glad to hear from you. I am the creature of accident. I am not to blame for the absurd vogue of my doggerel. If you want to read something to purge your soul, some good, honest, hard, horse sense, read my Castilian Days-when they come out, which will be next fall. Meanwhile I will read your $\mathrm{G}$ - article which has made a hit, and wait for you. When will you be here.

Your letter is dated $\mathrm{R}$ - and postmarked $\mathrm{P}$ - I will put on my overcoat and send this screed on its spiral way.

Yours,

J. H.

HAY TO R. H. STODDARD.

The Tribune, October 5, 1871.

MY DEAR MR. STODDARD :

I hope you will not suspect me of affectation when I tell you I don't want to go into G-_'s book. I am no poet,-I make no claim whatever that way. There is hardly one educated man in 
my acquaintance but has written as much verse as I. By an unlucky accident I put a quaint story into rhyme and gave it to $\mathrm{R}$ _ , and the people who wouldn't read you or 'Temnyson to save your lives, read this, and guffawed over it, and-me voila a poet! Then $\mathrm{O}$ - came and tempted me, and the mischief was done.

Now if I keep quiet a year or two, all that will be forgotten and will be as if it never was. I do not want the memory of it preserved in standard books which will go into libraries.

There is nothing I respect so much as the name of a poet. If I had done anything like your work or Stedman's, I would be indifferently conceited over it. But I have never written a rhyme which deserved to be printed,- - still less to be gathered up and kept as specimens of literature. I can do some things as well as most men of my weight, but poems are not of them. Let me up, and pass on to the next man in $\mathrm{H}-$ !

I also read with infinite delight $\mathrm{H}-$ _'s savage article on $\mathrm{M} \longrightarrow$. I don't agree with it. I think the wild cuss is a poet. But $\mathrm{H}$ _ did sling his scalpel in a most stylish way. I believe I would have enjoyed it if I had been the subject. . . . . 


\section{HAY TO HOWELLS.}

\section{New York Tribune, December 25, 1871.}

MY DEAR HOWELLS:

I am badly frightened about that article. I will do it to-morrow or next day if possible; but I am awfully worritted with many things, and need twenty-five hours a day.

Here is the paragraph of editorial to which you refer. I am delighted with the success of your book, and was sure of it, though the delay of the second edition is infamous and shows little faith. I met an angry man this morning who went to Dutton's for the Wedding Journey and not finding it, had to buy Casiilian Days.

\section{HAY TO WHITELAW REID.}

New York Tribune, N. Y.

February 11, 1872.

MY DEAR MR. REID :

Castelar writes to me, wanting to write a weekly, bi-weekly, or monthly "review" for the Tribune. Do you think you want it, and if so, how much? 
HAY TO WHITELAW REID.

New York Tribune, N. Y.

February 16, 1872.

MY DEAR REID :

J. $\mathrm{Y}-\mathrm{S}$ - of Chicago was here this morning, and said he might call again during the day. If he comes, give him welcome. You know who he is-one of the salt. He is starting a new paper in Chicago, and wants advice. He has loads of money-more than he will have when his paper is a year older. $\mathrm{He}$ is coming with me to the $C-$ to-morrow night.

\section{HAY TO WHITELAW REID.}

New York Tribune, N. Y.

$$
\text { August 14, } 1873 .
$$

MY DEAR REID :

I think you got away from New York not one moment too soon. You are much better where you are, and I can see no reason why you should be in a hurry to come back. Even if you found it necessary to be here for an hour or so for any special reason, you could go back to S___ again 
the same day. You will be wise to stay away till you are well.

I took dinner at $\mathrm{O}$ - Tuesday with Mrs. $\mathrm{S}$ - was absent from the Tribune just three hours, two of which on the cars. Heard a great deal of motherly abuse of you for ruining your constitution with hard work. The lovely lady has gone to $\mathrm{A}-$, where your name will be taught to all the echoes.

I made a toilsome journey to $\mathrm{S}$ - last Saturday and came back Monday. Next Saturday I am going to $\mathrm{S} \longrightarrow$, and will return Saturday night or Sunday morning. I am getting completely bunged up by my travels,-have got a good, honest catarrh which will last a week or two longer. But I am sustained and soothed. . . . I wish I could see you in the same predicament. The fact of being in love, and seeing a good woman in love also, is a wonderfully awakening thing. I would not have died before this happened for a great deal of coin.

Get well, and then get engaged. Time flies.

Give my regards to Mr. and Mrs. P- 
HAY TO NICOLAY.

\section{August 27, 1873.}

MY DEAR NICOLAY :

I ought not to leave you to learn from strangers that I am engaged to be married to Miss Clara S- of Cleveland, Ohio. I do not know when it will be. There will be an internecine war before Mrs. S_ consents to give up her daughter-wherein I sympathise with her. But before many centuries I shall win. She is a very estimable young person-large, handsome and good. I never found life worth while before. ${ }^{1}$

HAY TO WHITELAW REID.

Executive Department, Mayor's Office, Springfield, Ill., Sept. 3, 1873.

MY DEAR REID :

Thus far I have marched without accident. I was to have gone on to $\mathrm{W}-$ to-day, but my brother was trying some firemen for bathing a

${ }^{1}$ The marriage took place in Cleveland, O., February 4, 1874. 
yellow dog in kerosene and setting him on fire. I am happy to state they no longer belong to the Fire Department. I had a cheerful day in C-cool and shady walk in E-Avenue,-everything as heart could desire. I am getting sick of railroads however, and shall be glad to get home to rest.

Is there anything wrong with $\mathrm{B}-$ ? The Associated Press seems to avoid mentioning the $T$ - It says for instance, "The Mayor of $\mathrm{P} \longrightarrow, \mathrm{O} \longrightarrow$, in answer to an anonymous correspondent," writes, etc., and then gives his letter to the $T-$. One or two other items from the $T$ - were treated the same way.

I saw $\mathrm{M}$ - who is getting more and more sassy. He says editorially that both $\mathrm{A} \longrightarrow$ and $\mathrm{A}$ — are a disgrace, etc. He is very little better than an independent journalist. He says it don't hurt the paper. He sent his love to you and was greatly impressed by the picture of the new building.

If there are any letters for me in the Box, please ask Mr. N-— to send them to me at $\mathrm{W}-$ -

I thought I was going to have cool weather, but to-day it is tropical. The cholera has burst 
out again with great fury in the southern part of the State, but M. le Maire says he has pared its claws here. He hauled up several of the richest and oldest citizens here for not policeing their property-including his own grave and reverend uncle. It did not amuse them.

If you can find a minute in the intervals of the mad delight of house-hunting, please tell me how things are.

By the way, I met at B-'s two of the most interesting people I have ever seen in my life; Lawrence Olyphant and his wife, who was a l'Estrange. It is a combination I have never seen before, the highest knowledge of Society and the world, combined with a mystic and passionate philanthropy. He talked to me in a way that indicated he would like to write occasionally for the $T$ - I think it might be worth while to ask him. He is the author of that brilliant book Piccadilly, and was for a long time Paris correspondent of the London $T-$ He knows everybody and everything. Dick $\mathrm{T} \longrightarrow$ was there, and said he wanted to meet you. Dwas there, but I don't recall his saying anything of the kind. 
HAY TO E. M. STANTON.

111 East 25th Street, January 8, 1874.

MY DEAR STANTON :

I spoke to Mr. R- of Mr. R—'s book and he referred to Mr. R_, our literary Court of last resort. Let us hope for a just and gentle judgment.

I am going to be married. If you want to see the last of me, be at Mr. Stone's, 113 Euclid Avenue, Cleveland, Ohio, on the evening of the 4th of February, and I will show you a lovely woman $^{1}$ in a white dress and a man in a black coat, who is now and always

\section{Yours faithfully.}

HAY TO ALBERT RHODES.

New York, May 15, 1874.

MY DEAR RHODES:

This will be given you by W. F. G. SEsq., one of the first of living journalists. He sails with the Black Crook artists and the Pil-

${ }^{1}$ Her name for this month only is Miss Clara L. Stone. 
grims of Rome and partakes of the nature of both. Please tell him where to go in Paris to hear the best preaching, etc., etc.

$\mathrm{He}$ is a valuable man. Take good care of him. Yours truly.

\section{HAY TO ALBERT RHODES.}

New York, January 28, 1875.

\section{MY DEAR RHODES :}

I was right glad to hear from you and to learn that you thought of coming back to us. You have evidently had a good time, and I suppose you are now coming back to let loose a brilliant little book upon the unresisting world. Come, and have the success you have so well merited.

I am leading a quiet life and shall be glad to have you égayer it somewhat with your French airs and graces. We are established for a year at 11 East — Street (wide street you know, near 5th Avenue) in a pleasant house, and there is always something in the larder (I don't know what a larder is, but it is euphonious) wherewith to barricade your bowel against the wolf.

Give my love to $\mathrm{N} \longrightarrow$ and $\mathrm{Mr}$. $\mathrm{N} \longrightarrow$; what 
a handsome and serious fellow he has grown to be! As to your suggestion about posterity, it has never struck me in that way. I do not agree with you-but I am impressed by what you say and when you come over you may perchance convince me.

$$
\text { Yours fondly. }
$$

HAY TO WHITELAW REID.

15 March, 1875.

DEAR REID :

It is painful, but I must tell you. My wife says, when you come to the house, that you have got to hold the baby.

HAY TO WHITELAW REID.

$$
\text { April 29, } 1875 .
$$

MY DEAR REID :

I can't walk, stand or sit-but by special grace am still able to lie on my stomach. If you can think of a subject you would like to have treated from that point of view, send it over, and I will worry it.

Yours in Job-like dejection. 


\section{HAY TO ALBERT RHODES.}

\section{Euclid Avenue,}

Cleveland, Ohio, July 9, 1875.

DEAR RHODES :

Many thanks for your recollection. But Mrs. $\mathrm{H}-$ saw your book at a store in this city and made cadeau of it to me. I have not read it yet, for Madame has been devouring it herself and occasionally reads a page aloud to me, which justifies my long-standing opinion of your sparkling style and observant eye. Please accept our thanks for the pleasure the book has given us, as much as if we had got it for nothing.

I have been a little of everywhere since I saw you. First I went to Boston, then to Illinois where I passed ten days at my father's and met all my brethren who are still alive.

I shall be here, I presume, all summer, trying to learn the multiplication table and watching my baby grow.

Yours faithfully. 
HAY TO WHITELAW REID.

\author{
34 Public Square. \\ Cleveland, July 19, 1875.
}

MY DEAR MR. REID :

I merely put that address there for the sake of grandeur, to let you know that we have at last got into an office and have carpeted it and set up desks and bought some note paper and a wastebasket, and are now ready to skin the pensive Buckeye with neatness and despatch.

.... Don't think of sending me the Thiers autograph. I would have it prettily framed, if I were you. It is a very nice thing for your children. It is the thanks of the French Republic, voyez-vous!

(Mrs. S_ gave me to-day a portrait of herself with my wife (ætat five months) sitting in her lap. It is the image of my infant to-day, which I hope disposes forever of the foul and widely-circulated calumny that the baby looks likes me.)

That parenthesis was suggested by "your children." Don't you think, really now, that you are neglecting them shamefully? I never saw so many pretty girls as there are in $\mathrm{C}$ Hurry along! 
The $T$ - is marvellously full and good. I can't read it all nowadays, but I struggle through as much as $I$ can stand. It is a far bigger paper than I thought when I was there in the kitchen helping to cook it. Only don't waste your nervous system altogether. Save $\mathrm{H}-$ and some of the rest, and you can keep it as good as it is for a life-time.

HAY TO NICOLAY.

Cleveland, O., June 23, 1876.

MY DEAR NICOLAY :

I have been dreading and postponing for sometime the writing of this letter. I hate to tell bad news-and my news is bad. I went industriously to work last winter. Got a fine start on my material and commenced putting it in shape. I had even written a few pages when I was struck with partial blindness. I have had numerous doctors at me almost ever since but the trouble is not yet over. During the last month my general health has been completely restored, and I think I see the case more clearly than before and hope by taking it easy this summer to be well next 
fall. That is the whole story, and I have never had the heart to write it before. I write now because I am greatly encouraged and begin to think I shall soon be all right again.

HAY TO WHITELAW REID.

536 Euclid Avenue, Cleveland, November 13, 1876.

MY DEAR REID:

My $T$ - commenced coming the day after I telegraphed. I suppose it may have gone wrong a day or two on account of there being no street No. on the address, but it is all right now, and with a boy and a $T$ - in the house we are sufficiently furnished to feel comfortable. The young man's name is Adelbert Stone Hay,-no Jr. in mine, if you please, though I fought off the name single-handed against great odds. $\mathrm{He}$ is a fine little man-child, ugly and strong, lean and big-boned, with a boundless capacity for sleeping and eating, and as yet no music in him. Long may he fight it out on that line. There is nothing in which a bachelor's ignorance shines out so flagrantly as in his feeble-minded convic- 
tion that babies look alike. There is no familylikeness even, between my two. My little girl, who was quite ugly at first, has become very pretty. I do not think the boy ever will, from present appearances, but he looks already like a railroad maker and statesman. Mrs. $\mathrm{H}-$, the Lord be thank't, is very well. The babies take none of her health or good looks away from her.

I believe I won't say anything about election. I think the $T$ - has nothing to regret except a few digs at Uncle Sam which were not quite fair, and your article on W-, D- A. Which-well-hold on-let bygones be buried with the decomposed past!

Give my love to $\mathrm{T}-$ and $\mathrm{B}-$, and tell them to sling a column and a half or so, in memory of one who wishes he was back at his desk-Quid rides?

\section{HAY TO HOWELLS.}

506 Euclid Avenue.

Cleveland, O., February 20, 1877.

MY DEAR HOWELLS :

I send a few lines of vituperation for the Contributor's Club as your wisdom may ordain. 
I hear you are to write a "No Name" story, but I do not believe a word of it. Your name is too valuable to veil. If you do, let me know, in strict confidence. I cannot afford to read the "No Name" books. I fear I might plunge into some such ditch of $\mathrm{M}-$ and water as $\mathrm{D} \longrightarrow$ Y Your comedy is delicious. My wife reads it to me. The last $A-$ has come, and we think that no Magazine has a right to two things so good as you and James at once. Is not the American astonishing even to us who always believed in him? Of course not " aesthetically attractive" but-well! well! let us be patient! Such things have always been.

I thank you for my share of the Life of $\mathrm{H}-$. It cheered and comforted me a good deal. The Governor's conduct for the last year has been a complete confirmation of all you said. I liked $\mathrm{T}$ —_ very much, - voted for him for Governor - the only Democratic vote I ever cast. I did not vote for $\mathrm{G} \longrightarrow$; but I never allowed myself to expect as much from any man as I feel forced now to hope from H-. We are in a bad way. That herd of wild asses' colts in Washington, braying and kicking up their heels, is an unsatisfactory result of a hundred years of Democracy. 
Of course I do not expect from Mr. H- a reform of the Civil Service. It is too much for any man to accomplish. Human nature and free suffrage are against it. But he can and will, I feel sure, chasten the outrageous indecency of the present system as much as anyone could. . .

\section{HAY TO NICOLAY.}

Cleveland, O., August 9, 1877.

MY DEAR NICOLAY:

I have hardly dared to write to you for some little time for fear of making illusory promises; but I think I can say now that I am started and can keep at work. If nothing happens adversely, we can have Lincoln inaugurated by the 4 th of March, 1878. I have been very hard at work for a month or so, and sat down some weeks ago to writing. I have written from nine to ten thousand words (that is the only definite way of stating it) and have brought up to 1830 . I do not anticipate any bad delays unless my health should give way again. My old foe, the headache, is lying in wait for me, but I hope to get free. I 
write with great labor and difficulty-my imagination is all gone-a good riddance. I shall never write easily and fluently again. . . .

\section{HAY TO WHITELAW REID.}

Cleveland, November 26, 1877.

DEAR REID :

.... I do not envy your feelings when you see who the successor of $\mathrm{S}-$ will be. I have carefully considered your objections to him. You evidently don't believe the shoddy or gun-stories, -no more than I do. But you are agin him because he gives good dinners, and sometimes invites Democrats. This and the other infamy, that Mrs. S_ once gave some private theatricals and reserved a few seats for the Diplomatic Corps, cooked his goose. Now this fixes you also. I have had good dinners at your house,- - there were Democrats present,-all the seats were reserved!! Good bye, sweet prince, you can never be a foreign minister!

On the other hand, the $T$ - can feel cocky no end over $\mathrm{P}-$ and $\mathrm{C}-$, and thank heaven that the unclean things have never had its good 
word. How Nemesis has been sloshing around during the last year or two! Only she will be off duty when $\mathrm{B}$ - takes his seat in the Senate.

HAY TO ROBERT LINCOLN.

506 Euclid Avenue.

Cleveland, O., February 14, 1878.

MY DEAR ROBERT:

I have been spending a fortnight in Washington with Nicolay and am very much gratified at the work he has done in arranging your papers and in preparing for our history. Besides putting the Ms. in admirable order, he has made a first rate beginning at the chapters allotted to him. I also have had pretty good luck during the last season and we now consider the big job well begun. It will take a long time yet, but we are in no hurry and I presume you are not. We have made such arrangements that in case either of Nicolay's death or mine your property is safe and the work as far done is available for the survivor. On the way home I heard of the death of our old friend Mr. W-. It is of great importance to us that we should get access to his diary and 
other papers. I know how much $\mathrm{E}$ - thinks of you, and he probably knows the interest which his father took in our work. As soon as you think proper I would like to have you suggest to $\mathrm{E}$ - that he should put the diary in our hands; we should, of course, pledge ourselves to regard it confidentially until our history is published, and even then to be guided by his wishes in regard to what should be used. I wish I could see you here sometime. Could you not run down for a few days. We could show you and Mrs. L- a pretty town and plenty of sleigh-riding, although in other amusements we are rather deficient.

\section{Yours faithfully.}

I saw the President in Washington. The only thing of any importance he talked about was you. You evidently made a great impression on his Excellency.

HAY TO NICOLAY.

Cleveland, O., February 27, 1878. DEAR NICOLAY :

I have devoted a day or two to looking over my note books, and am prepared to sit down on 
you with some force. I have a large amount of valuable notes-made on the spot, the extent and value of which I had quite forgotten. They are weak in 1861, not very good for '62 except in respect to Second Bull Run; but quite full and valuable for ' 63 and '64. They are not in good shape. I do not know but what I may try to have them copied by typewriter. . . .

Do you understand Mr. W_'s reference to a "Memorandum" written by Lincoln in 1864 in anticipation of defeat in "Atlantic"? I have the original Memorandum; he gave it to me, in the presence of the Cabinet, after his reëlection. $I$ have the whole occurrence in my note book. As I was leaving the room with it, Judge Basked me for a copy. I cussed silently-then $\mathrm{W}$ - asked for one, and then everybody. Charlie $\mathrm{P}$ - made the copies, and I have been dreading their reappearance, and felt a little relieved that our old friend had finished his work without an allusion to this matter-when, lo! in the very last Article he refers to it. If he has not left other Articles in ms. we are still safe; but if he has, he will be sure to copy this precious document in fuli in the next one. . . . 
HAY TO NICOLAY.

Cleveland, Ohio, April 6, 1878.

DEAR NICOLAY :

I have some bad news and may as well blurt it out at once. I am used up the Doctor says, and must lie off all summer. He suggests-see how great minds jump together-what you didColorado. Only you suggested taking me. Eh bien! Can you go? If you can't I am rather inclined to Switzerland instead. If you can go let me know and when you can get off. Let me know at once.

HAY TO WHITELAW REID.

514 Euclid Avenue. Cleveland, O., July 5, 1878.

DEAR MR. REID:

.... I think I shall have a good deal of leisure here, and hope to do some work for the $T$ - The last month has been full of running around, but I am now fixed for the summer. I met $\mathrm{N}$ - at Springfield and found he had made great progress in the collection of material. 
I am now almost ready to go to work myself. We have not yet got an office, having slipped up on one or two arrangements, but shall probably decide to-day on our rooms. I shall then spend several hours a day in them, and as there will not be enough business to occupy the time, I shall be driven in self-defense to you and Lincoln, par nobile hostium.

I agree with you about B-'s article. It is very clever-too much so in fact. The parallel is so fine as to be vague. If $\mathrm{D} \longrightarrow$ is to be attacked in the $T$ - our way is best. $\mathrm{He}$ should not be made the subject of fine satire.

I wish you could ever have as lazy a time as I had for ten days at W - - $W$-though I suppose you could not have endured it. We were all together, without our wives, and spent every precious minute of the time in loafing and remembering our childhood. I got acquainted with my brother If over again, and liked him better than ever. If I had not been too lazy to take down his talk, it would have been all good copy, about life on the frontier. But as I was going to say, I wish you would take care of yourself in some way. It is getting to be a mania with me, ... and I made myself a nuisance at Spring- 
field by croaking at $\mathrm{C}$ nearly twenty hours a day. I am grieved and ashamed to see that the $T$ is as good and better without me. Why can't you make up your mind to let it go a little while on the momentum you have given it! It is a tremendous paper. I see it more plainly than ever when I am away. Everyone I meet says the same thing; it has fairly conquered criticism. If you would now learn to sleep and eat like a Christian, it would be all the better for you and your congregation. . . .

HAY TO WHITELAW REID.

Cleveland, October 27, 1878.

DEAR REID :

.... I don't see any good reason why we should not set December 7 as the Saturday night on which you shall beguile Howells down to New York, and I will come too. Only you are not to have any spread on that evening, for we shall want to go to the Century.

Howells' play, produced here Friday, is a translation of that pathetic Spanish tragedy "Yorick," which you and I saw some years ago at the Fifth $3^{2}$ 
Avenue. Howells has greatly improved it. It is a beautiful tragedy now and Barrett played it magnificently-but it is too sombre and heartbreaking to have much money in it.

I have not congratulated you on your great coup. ${ }^{1}$ It is the biggest piece of intelligent journalism, as distinguished from mere enterprise, that has been done in the country. The leaderwriting about it has been as good as the cipherwork,-can't say better, for obvious reasons.

I have not thanked you either for taking me to $\mathrm{T}$ - that Sunday. I never had really talked with W- P before, and I should not have felt like leaving the world without meeting so original and loveable a character. $\mathrm{He}$ is charming-mind and heart both,--one of the fellows that ought to live forever to help sweeten a brackish world.

${ }^{1}$ Deciphering the Florida despatches. 
HAY TO HOWELLS.

Cleveland, O., October 28, 1878.

MY DEAR HOWELLS:

I went home last night moved and shaken to the core by your play, ${ }^{1}$ and I woke up this morning with that vague sense of calamity with which a sorrow of the night before tinges the morning. I hardly know how to begin my report to you. If the theatre was merely a temple of art and poetry I could congratulate you on a great and glorious triumph. I am sure I never saw Barrett play as well, with such sustaining agony of expression. I went in to see him after the second Act, and he was haggard as a ghost and drenched with perspiration, but he showed no diminution of energy in the last Act. The play throughout had a terrible clutch upon the feelings of the audience, in spite of the young man who played Edmund, who overdid his part and left the audience behind him with no inclination to catch up. In all Barrett's scenes the attention was painfully intense, $\bullet$ only interrupted by quick and electrical storms of applause. The audience was

${ }^{1}$ A Counterfeit Presentment. 
like your other one last year, an Atlantic Monthly crowd which crammed every inch of space. They appreciated the good acting and the good writing as well. The exquisite versification in the second Act, for instance, was remarked upon by a dozen people about me, who, I should have thought, would not care for such things. It was a great tragedy, nobly played, in short; and it had last night an honest and legitimate success. The success was yours, too, for it was a very different play from the one $I$ saw at the Fifth Avenue Theatre some years ago, improved almost beyond recognition. It was the best written play I have heard for a long time. Now shall I go on with the hateful candor of a friend, tell you the further impression it made on me? I do not believe that, as the play stands, it will ever have great runs, or make you much money. The plot is so simple, the story so sombre and heart-breaking, that after the play becomes known, few people will go to see it except those who enjoy the very best things in writing and acting. It is too concentrated, too intense. The five people in it are in such a profound agony that an ordinary audience would grow nervous. They must laugh once in a while, and if you do not give them the chance to do it 
legitimately, they will do it in the wrong places. I do not know how the Greeks managed with their awful simplicity and work, but Shakespeare had to throw in what I dare not call padding.

Perhaps I am croaking in vain, after all. The play is magnificent. I wonder how any contemporary Spaniard could have done it. Your part of the work, it seems to me, is faultless, and Barrett's is unquestionably the stoutest piece of work I ever saw him do. (You made an improvement in keeping Shakespeare behind the flies. He was almost grotesque in the original.) The applause was of the sharpest and most spontaneous kind and the people were roused and moved in a very uncommon way. Perhaps I am morbid and cannot look at the prosperous side of things, but I think you will prefer to have me say what I think, even if I am wrong. I am sure I never left a theatre feeling such a sense of tragedy as last night, except when I walked out of the Academy of Music one afternoon and felt that I ought to go and tell the police that Salvini had smothered his wife and killed himself.

Turning to brighter things, Mrs. H- and I are just starting across the ocean with Miss Blood, with the assurance of a happy voyage. 
The first number is delightful. It gives the pleasure we feel at the first note of Wilhelmi's fiddle; we know he can keep on doing it as long as he likes. ... .

\section{HAY TO NICOLAY. \\ Cleveland, O., January 11, 1879.}

MY DEAR NICOLAY :

I think Colorado must be the thing after all. I went to Europe in May, had the quietest summer of my life. Spent a month or so in England, loafing in city and country; did not go to a single dinner party or Opera; then loafed through Holland and Belgium up the Rhine to Schlangen, where we stayed a month; then a little of northern Italy and Switzerland, then the Exposition and Scotland, and a week's sleepy rest at Windermere and home. In all this I was more quiet than I would have been in Cleveland. After I got back I imagined I felt better for a month or so, but the other day I had the most ridiculous attack I have ever had-thought I was dead for half an hour. The Doctor said it was nothing at all serious-simply the effect of 
the cold. But I feel rickety yet. I have been trying my best to get to work again with very indifferent success. But I feel to-day as if I might make some headway for a while. I will write you later and tell you how I get on.

HAY TO NICOLAY.

506 Euclid Avenue.

Cleveland, O., March 30, 1879.

DEAR NICOLAY :

I saw to-day in the $G-$ a paragraph by $\mathrm{T}-$, on the authority of $\mathrm{F}-\mathrm{M}-$ of $\mathrm{C} \longrightarrow$, that I alone had finished the first volume of our History. I can't think M- could have made such a mistake. $\mathrm{T}$ - must have misunderstood him. Both the papers here have tried to interview me on the work. I requested them to say nothing, as we were not ready for any announcement; and they complied with my request. But it is useless to try to stop up all the possible leaks, and some of these times we will have to let something be said-in the $T$, I should say,-so that the truth may be known. Think of it a little, and when I see you, give me 
your views. When am I to see you? It looks now as if I could not get to Washington this spring. My poor mother has had a dreadful accident, breaking her thigh bone at the hip. I have been in Warsaw for three weeks, hardly expecting her to live from one day to anotherbut last week she began to rally and now we have strong hopes of her recovery.

.... I was getting along splendidly when this disaster happened. It throws me out, and I shall require some time to get in running order again. I have written now, in all, over 50,000 words. . . .

\section{HAY TO WHITELAW REID.}

Cleveland, O., June 9, 1879.

MY DEAR REID :

.... I passed the last week in Warsaw and on the road. My mother is very much better. She sits up several hours every day in her rolling chair, and propels herself about quite efficiently. She is as cheerful and witty as ever, and my father seems quite rejuvenated by her convalescence. So we shut our eyes to the fact that they are nearing 
four-score, and go on with the comforting delusion that they are immortal. ...

I never had a pleasanter visit than that one at your house. It is a permanent addition to $\mathrm{my}$ stock of happy recollections. . . .

\section{HAY TO WHITELAW REID.}

\section{Cleveland, O., August 20, 1879.}

TO THE EDITOR OF THE TRIBUNE:

Into whose hands these lines may fall, greeting: If it is Mr. Reid, hail! and welcome back to civilisation!

If it is $\mathrm{L} \longrightarrow$ or $\mathrm{N} \longrightarrow$, or some other D. D. literary feller.

I wish you would help our S- a little by sticking into your able and leading pages somewhere the of between the red lines.

I made this speech last night in the strongest Democratic Ward of $\mathrm{C}-$ to an audience nearly half Democrats, and there was nothing but approval manifested.

Yours in humble expectation,

Hay,

Reformed Tribune Man. 
HAY TO WHITELAW REID.

Cleveland, August 25, 1879.

MY DEAR REID :

As you never read anything but proofs, perhaps the form in which this oration is printed may induce you to cast your eagle eye over it. I am going to say it to a big crowd at North S- day after to-morrow - the Pioneers' Reunion,-all others are spurious.

We are having a red hot canvass,-our side especially; I am invited to make four speeches this week, and am not on any Committee's list either. I shall try it a little-slowly and gently at first, and find out whether I can. I don't call it making a speech unless a fellow can bore his audience heartily and thoroughly for an hour, without having written a word of it beforehand-like $\mathrm{W}-\mathrm{A}-$ and sich. 
HAY TO WHITELAW REID.

Cleveland, O., October 5, 1879.

MY DEAR REID :

I believe in my penitent heart I have not yet thanked you for the pretty pamphlet in which $\mathrm{H}$ - has made your Address permanent. It is little to say that it is the best thing anybody has done in that line. It is not only admirably written and thought, but it gives to laymen the best view of real journalism that has ever been put in print, and to newspaper men it is simply invaluable. It is crowded with facts which keep their places and do not jostle each other. It is so good that one is surprised to find it so enjoyable. There is no trace of the fine writing that "Agate" once delighted in ; but the style is an improvement on the old one, which was, as you know, a very good one for journalism. Well!-when you get this letter, we will both be past forty, and it is time for us to get down to our steady roadster pace.

I am making a speech nearly every night. Here is my last, made on the Square Saturday night to 5000 people, by the Brush light. Tell Mr. P_ he bullied me into it last Spring. 
HAY TO EVARTS.

506 Euclid Avenue, Cleveland, O.

October 28, 1879.

DEAR MR. EVARTS:

I have your letter of the 24th and I cannot express the sentiments of gratification with which I have read it. To be offered the privilege of succeeding Mr. S- as Assistant Secretary of State is an honor as far beyond my ambition as it is beyond my merits, and the generous courtesy with which you urge my acceptance of it, doubles the value of the offer. It is therefore with the greatest reluctance and with positive pain that I bring myself to say that I cannot assume the duties of this position which would otherwise be to me the most agreeable in the gift of the Government. Interests which I cannot disregard, make it impossible for me to be away from Cleveland this winter.

I hope you will permit me to say that the keenest regret $I$ feel in declining this position, is for the loss of the pleasure and benefit which I should derive from daily association with yourself. Begging that you will convey to the President my 
profound appreciation of the honor he and you have conferred upon me, and my sincere regret that is it impossible for me to avail myself of it. I remain, my dear Mr. Evarts, Faithfully yours, John Hay.

HAY TO HOWELLS.

\section{May 24, 1880.}

MY DEAR HOWELLS :

Thanks for M__ 's letter, which I return. His idea is as judicious as it is daring. A club which would hold him and you and me, and then reach out for $\mathrm{H}-$, etc., - and still keep modest,staggers and fatigues the faculty of wonder. I wish he and you would come down here and hold the first meeting of three at my house.

I feel what the French call a deaf rage when I think of your having spent a week in Washington, and my not having seen Mrs. $\mathrm{H} \longrightarrow$ at all, and you only a minute. If I were a saint it would be enough for me to know that you had a pleasant visit yourselves, but I cannot help feeling like the Dutchman who when he was in the calaboose and 
heard from a later arrival of an uproarious spree the night before when hogsheads of lager were drunk and two men killed-sighed with soft regret-_"And I was not dere."

I did not get the chance I wanted to avow my sin and ask absolution. I have positively and definitely given up Congress, and I shall hold no more office after next March. I think there is no such ashes-of-sodom fruit in the world, and I am out, finally, as soon as I can get away. I would give a pot of money to get out to-day,--nothing but my personal regard for Mr. E- keeps me through the administration. Yet this is the pleasantest place in the government, and I like and respect the principal people in office,-which makes an a fortiori case against anything else. . . .

\section{HAY TO RHODES. \\ Department of State, Washington, July 10, 1880.}

MY DEAR RHODES :

I have this day signed your commission as Consul at Rouen, the Secretary being at Windsor, getting in his hay. 
I am glad that in my short term of office I have found the opportunity to do you this slight service. My term is now one-half over, and I look forward to the 4th of March with hungry anticipation. If my present mind holds, I will never again take an office-certainly not for years to come.

I spent the 4th of July with my children at Cleveland-they are three; two girls and a boy,and there is nothing in this hot and dusty world which will compensate for the loss of their society.

I know well enough that after I have spent a year at home I shall have regrets for Washington and Europe. But foreseeing the regret as I do, I know I can endure it better than public servicewhich I have solemnly foresworn. . . . .

HAY TO WHITELAW REID.

Washington, D. C.

August 4, 1880.

MY DEAR REID :

We had an excellent meeting at $\mathrm{C}-$ on the 31st. The Opera House which was loaned to me by the proprietor for the first time in its history 
for a political meeting, was crowded from top to bottom, and the best of good feeling prevailed. My speech was lengthened to an hour and threequarters by the kind participation of the audience.

I think there is no necessity whatever for any desperate measures in that district. I paid a great deal of attention to the matter while I was there for four days, and am convinced that $\mathrm{T}$ - will get through. The bolt will grow weaker in my opinion every day. I went out to $M-$ on Monday afternoon, and had a long talk with Gen'l G-. I think he agrees with me that the less said about the bolt the better. A considerable number of the bolters were on the platform with me, and evidently expected a considerable chastisement; but I did not refer to the matter at all, which was an agreeable disappointment.

I wish I could talk with you for an hour or two, but I see no prospect of it at present. I thank you cordially for the splendid setting up the $T$ - gave me, which made me blush at the praise of my own loveliness.

I have found out the sure way to get civil words from everybody, in C-Co., at last-refuse to run for Congress. I will keep it up. 
Children all well and happy, and the house an affliction to leave.

Only wait till March 4th! That's all!

HAY TO R. W. GILDER.

Department of State, Washington, August 5, 1880.

MY DEAR GILDER:

I received your letter of the 29th July while I was at Cleveland the other day, "opening the campaign," as if it were an oyster.

Your proposition is certainly a very flattering one-and one not to be lightly rejected. I will talk with Nicolay about it as soon as I can get speech of him. At first thought it seems to me impossible on account of the length of our work. It will be,-this is a dense secret,-five or six volumes, and those who began to read it in Scribner (now The Century), in the flush of youth, would go tottering to their graves before the end came. But a series of consecutive chapters might be arranged;-I don't know. I will talk with Nicolay about it, and let you know. 
I am glad to learn that you and your family are so well. Mrs. H- and my two girls and one boy are cool and comfortable in Cleveland-where I wish I were. But I shall go back there on the 4 th of next March, and then never, no never, will I surrender my life and liberty and pursuit of happiness to public office again. I have made a little transaction with my civic conscience thus :I will spend every year as much time and money as I can afford, in politics, and that is all anybody can ask of me. But run for office I never did and never will; and hold office, I shall do nevermore. I shall keep this vow-unless I forget it.

HAY TO HOWELLS.

Department of State, August 9, 1880.

MY DEAR HOWELLS:

I received your memorial with its "memorable names," and by the same mail a copy of the Treaty from Mr. H_. I presented them to the Secretary and had a talk with him about the matter. $\mathrm{He}$ is favorably inclined, but thinks perhaps it may be better to conduct the negotia- 
tions from this side, and as Sir E- T- - is away, it will be necessary to wait till he returns.

I sent you to-day a copy of the speech I made a week ago in Cleveland. I had a large audience, a beautiful house to speak in, and much sympathy.

I still mourn over that visit of yours in which I did not really see you. Can't you come again, and come to my house,-but of course you will see much more from the Executive Palace.

HAY TO GENERAL GARFIELD.

1400 Massachusetts Ave.,

Washington, Oct. 18, 1880.

DEAR GENERAL GARFIELD :

I did not come down on you while I was at Cleveland, simply because I felt that the truest service I could render would be to stay awaybut as it will not take a minute of your time to read this note, I write it to offer my congratulations from the bottom of my heart. I believe that you will carry every Northern State and will go into the Presidency with the most magnificent moral backing anyone has had in our time. I 
know you will feel no selfish gratification in this, but your opportunities for good will be incalculable. Great things are to happen under your administration. It would be an impertinence for me to intrude upon the high subjects that must now be occupying your mind. But even at the risk of seeming presumptuous I will rid myself of this word which has positively haunted me for a week. Beware of your own generosity! On the 2nd of November, you ("not Launcelot nor another") are to be made our President. I believe it is to be an administration full of glory and benefit to the country-and it will be glorious and fruitful just in the proportion that it is your own. You do not need the whispered admonition of the ancient monarchs, "Remember thou art mortal." It will pay you to keep a cheap friend to drone continually in your ear, "It was you who were nominated at Chicago and elected by the people." 
HAY TO HOWELLS.

Department of State,

October 24, 1880.

MY DEAR HOWELLS :

I hope that we are really approaching a negotiation of the copyright business. I wrote an instruction to Mr. L_- about it last August, and he has been feeling the pulse of the authors and publishers over there, and now reports that the sentiment is altogether favorable among them and in the government. So that, if $\mathrm{G}-$ is elected by a good big majority next week,-enough to scare our friends the enemy out of any countingout intentions they may cherish,- - that will give us a comparatively quiet winter, and I sincerely hope something may be accomplished. Still, if you would come down and stand around a little, it would be all the better. As it is to be my last winter here, I should be very glad to have you. If the President could spare you-you means Mrs. $\mathrm{H}$ - and you,-we would be glad to take you in, and if he cannot, then we might "divide time" in the Red Shirt manner.

... I did not get the rest I needed out of my vacation. I was harnessed up a few hours after I 
got home, and kept at it. One thing was rather pleasant. I spoke at Warsaw in the open air, in the square in front of my father's house. My father, aet. 80, was on the stand, and my mother heard me from her window. It was my first speech of any length in the open air. There was a slight breeze against me, but I spoke nearly two hours, with no distress to anybody but the ungodly, and was fresh as paint at the end.

I share the pleasure you must feel in the great and solid success of The Undiscovered Country, and am happy to know we are to have another one this year.

\section{HAY TO GENERAL GARFIELD.}

\section{Massachusetts Ave.,}

Christmas Day, 1880.

DEAR GENERAL GARFIELD :

$I$ received several days ago from $\mathrm{W}-\mathrm{R}$ an intimation of what you were thinking of for me, and I immediately wrote to him expressing my deep sense of the honor done me by such thought, and the sincere regret $I$ felt that it was not in my power to take the place. I agree with 
you in regarding the position as one of the greatest importance and shall always be proud that you thought of me in connection with it.

I have carried your letter in my pocket and the contents of it in my head and my heart, for several days, with the most earnest desire to catch myself in such a state of mind that I might write and tell you I would undertake the important and honorable duty you offer me. But I cannot delay my answer any longer, and so must say how sorry I am that I cannot see the way clear to doing it. If I could share your own view of my fitness for the place I should be inclined to sacrifice all other considerations and go to work. But I am not. To do a thing well a man must take some pleasure in it, and while the prospects of spending a year or so in intimate relations with you and Mrs. $\mathrm{G}$ - affords a temptation almost more than I can resist, the other half of the work, the contact with the greed and selfishness of office-seekers and bulldozing Congressmen, is unspeakably repulsive to me. It caused me last Spring to refuse, definitely and forever, to run for Congress. It has poisoned all the pleasure I should otherwise have derived from a conscientious and not unsuccessful discharge of my duties in the State Depart- 
ment. The constant contact with envy, meanness, ignorance, and the swinish selfishness which ignorance breeds, needs a stronger heart and a more obedient nervous system than I can boast. I am not going back on Democracy. It is a good thing-the hope and salvation of the world. I mean simply that I am not fit for public office. You will find someone, I am sure, who can do these things much better than I could, and will take pleasure in them as well.

All through the heats of last summer I looked forward to the 4th of March as the day of my deliverance. I promised my family-I promised Mr. S- - who at considerable inconvenience has taken care of my affairs, that I would come home at that time-and although I know that he would acquiesce cheerfully in anything I should do, I should feel some remorse in breaking up the family arrangements for the coming summer. I do not know that I have much hope of ever improving my health, but the doctors give me the usual futile assurance that I will be better out of Washington in the summer time.

I did not mean to make a long letter of this, but the signal honor you have done me in selecting me in the place of the Government nearest 
yourself, has deeply touched me and I could not acknowledge it by a simple refusal. I felt that I ought to tell you some of my reasons for declining, although they are of a sort that a man of your firm and even character may think trivial and not entirely creditable to me.

There is work for all of us during the next four years, and though you are to have the great rôle, all men of good will can help more or less. I shall do my share in C-, and now that I am cured of my momentary error about going to Congress, I can do better work than I have ever done before. I shall have a good deal of leisure and shall always be at your service for anything"except these bonds."

Mrs. H- sends her regards to Mrs. GI have of course talked fully with her. She saw both sides of the question, but resolutely refused to assist me in the decision.

Sincerely and gratefully yours.

Dec. 26. I had finished my letter and gone to bed when telegrams came from Mr. S- and Mr. N_ asking me to come to Cleveland. I would start at once but for one thing. The President and Secretary of State insist, much to 
my chagrin, upon my representing them at the International Sanitary Conference called for Saturday next, and I fear I may have to preside at it. If so this week must all be taken in getting ready for this duty-disagreeable and unsuitable as it is.

I expect Mr. S— here next Friday. J. H.

HAY TO GENERAL GARFIELD.

Washington, D. C.

December 31, 1880.

DEAR GENERAL :

I have given strict and earnest thought to the matter of your offer all this week, but I cannot see any reason to change my mind. Every word I have heard was in favor of accepting, at first, but in every case,-R—, Mr. S- - Mr. S and my wife, agreed with me in the end. Even $\mathrm{N}-$ - - that Justus et tenax propositi vir, gave up the fight this morning after a campaign of as faithful work as I ever saw. I have myself been on the affirmative side in all my wishes and desires -but the reason, I feel sure, is on the other. I know I should not be the help to you which you have thought, but I should be, in the White 
House, the source of many embarrassments and complications.

I deeply regret that I am compelled to decline this most agreeable and honorable service. I wish I could make you see that $I$ do it in your interests more than in my own. I have had to resist constantly the temptation offered by the pleasures and enjoyments which such a position promises. But regretting all this as $\mathrm{I}$ do, I know that my decision is right. There are many things in which no man can serve you. There are paths which you must traverse absolutely alone. The solitude which seems to you a penalty of your high office, you will find a blessing which can only be gained by wrestling. The foot-pad, the cutpurse, and the sycophant will always be ready to crowd their company on you. You will find reserve only among honest men.

I wish I could save you one moment of annoyance or perplexity, but it is hardly possible that anyone can do that. It is a comfort to know you go into the Presidency with the best equipment possible. Besides the qualities that are personal to you, you know more of the past and present of government, more history and more politics than any man since the younger Adams, and you are free from 
his peculiar infirmities of temper, which so narrowed and distorted his views. "One thing thou lackest yet;" and that is a slight ossification of the heart. I woefully fear you will try too hard to make everybody happy-an office which is outside of your constitutional powers. Confine your efforts in that direction, do as you think right, and it will be right nine times in ten and not far from wrong the tenth time, though the heathen rage and the people imagine a vain thing. Mrs. $\mathrm{H} \longrightarrow$ joins me in wishing all good things for you and Mrs. Garfield.

Faithfully yours.

HAY TO WHITELAW REID.

Department of State, Washington, February 11, 1881.

MY DEAR W- R- :

My heart is full of your happiness. I give you a thousand congratulations. The best thing has happened to you that could happen. You will be at peace the rest of your life so far as the greatest of all questions is concerned. You will 
have a good wife-good through and throughand I can tell you what that amounts to.

I need not tell you how I have desired and hoped for this. I have rarely met a young lady whom I liked so much at first sight as Miss $\mathrm{M}$ — ; and Mrs. H_ sanctioned my judgment of her noble qualities by some feminine judicial process which does not require long acquaintance. . . . .

The proposition on your last page takes my breath away. I suppose I shall decline it finally, but I shall take pleasure in thinking it over for a while. It is a great temptation.

I had a letter to you lying sealed on the table when this momentous missive was handed to me. But I tore it up-it was all about politics, new cabinets, and myself, and such small deer, not worthy of your present frame of mind.

Well! God bless you and yours, now and always! 
HAY TO WHITELAW REID.

New York Tribune, N. Y.,

May 7, 1881.

MY DEAR REID :

Allow me to congratulate you and Mrs. Ron your safe and pleasant voyage. . . .

I get on reasonably well. J-J- comes down on us for State Charities Aid to the tune of a column or two, and B- slopped over badly in an editorial this morning which I overlooked by accident-but nobody remembers errors of taste more than a day. . . .

$\mathrm{W}$ - $\mathrm{P}$ - was confirmed before you were out of the harbor. As you get the $T-$ I will not send you my ed. head on him. I hope he will enjoy himself more than he now thinks he will.

I shall write to you once in a while with perfect freedom. .. Good luck and happy days for you and your wife. 
HAY TO WHITELAW REID.

\author{
New York Tribune, \\ New York, May 26th, 1881.
}

\title{
MY DEAR REID :
}

So you are married one month from to-day and I am Editor of the $T-$ ad interim the same length of time. I hope your experience has been less stormy and more amusing than mine. What a time we have had! I do not regret it in the least-as a fight like this has been a godsend in what would otherwise have been a dull season. I think we have got on very well-behind none of them in news and out of sight in editorial. I will not indulge in prophecy with half a dozen cables between us, but to speak of certainties $\mathrm{R}$ - is finished. That Olympian brow will never again garner up the thousands of yore. Of course we shall have a bad state of things for a while and shall almost certainly lose the state next fall. But that will be after your return, and I can charge it to $m y$ leaving the $T$ -

The whole thing has been a freak of insanity on the part of a man who has lost sight of his true relations with the rest of the world. It was the 
logical result of the personality of $\mathrm{C}-$ and the workings of the Boss system.

$\mathrm{S}-$ begins his editorial work on the $P$ to-day with a long, serious leader on civil service reform. Miss $\mathrm{R}$ - is, I think, looking better than when you left. She plays the banjo and piano-rides and receives visits and seems very gay and happy.

So far nothing has happened over here to disturb your equanimity or cloud your honeymoon. Enjoy yourself as much as possible. I think we can keep the ship off the rocks.

Give my regards to Mrs. R- and believe me,

Faithfully yours.

\section{HAY TO ALBERT RHODES.}

Department of State, Washington, June 8, 1881.

MY DEAR RHODES :

I received your letter of the $22 \mathrm{nd}$ and the Vie Moderne at the same time. I thank you very much for sending it to me. I have always been greatly interested in Flaubert's work and am glad 
to know something of the man. I have read, I believe, all his works except the Education Sentimental, which I see you call in your admirable letter to the $T$ _ "the weakling of his brain" -so perhaps I have not lost much in missing that. I am always glad to hear from you. I have no news to tell you except that I have two daughters and a son-all healthy and happy-and that I have only one aspiration in life and that is twoto get out of office and to stop having headache.

Yours sincerely,

J. H.

HAY TO WHITELAW REID.

New York Tribune, N. Y., June 29, 1881.

MY DEAR REID :

... I think there is nothing over here which need trouble you. The $T-$ seems to suit everybody but the ungodly. $\mathrm{H}-\mathrm{H}-$ goes for me every day in eight or ten places, but as it amuses him, and I have adopted my great patent remedy of not reading him, I only know it from $\mathrm{B}$ - and Miss $\mathrm{H}$ - who come in to console $5^{2}$ 
me when he is unusually violent,-and so I do not object to it. The $C-T-$ had a lot of filthy little digs at both you and me, till I frankly asked $J-M-$ to put a stop to it, which he did. It was the volunteer malignity of some "funny man" who wanted a "shining mark." That is to me one of the most curious things in our journalism-the way a man who has never seen you and knows nothing about you, will take a furious antipathy to you and blackguard you for months together, without letting up.

HAY TO WHITELAW REID.

New York Tribune, N. Y.,

August 13, 1881.

MY DEAR REID :

Our annals are dull-which means that everything seems to be going on satisfactorily.

I am wretchedly lonesome.

$\mathrm{C}-\mathrm{K}-\mathrm{h}$ has gone to California. Mrs. $\mathrm{H}-$ has gone to Cleveland,- - though she is coming back next week, and we shall spend Sunday at W- with the E- young ladies. 
I must steal a week next month or the month after to go to $\mathrm{W}$ - and see my mother, who is not very well.

$\mathrm{H}-$ is perhaps a little better-feels so anyhow. Did you read his review of $\mathrm{O}-$ $\mathrm{W}$ - - - by far the best-ten times over-that anybody has done here or in England. I am a little puzzled about him. He begs for work to be sent him, and his wife privately begs that we will not send him any-says it exhausts him. So I send him hardly anything, and tell him always to do it or not as he likes.

.... I am getting more abuse, now our fight is over, than ever before. The worst are your particular friends $\mathrm{H}-\mathrm{H}-$ and $\mathrm{J}-$ M_- They call on you loudly every day to hurry home and save your property. D- has broken out again worse than ever but as I never read him except when somebody jams him before me, he does not hurt.

All the same I will be glad when you get back and begin to take your own beatings regular.

It is perfectly amazing to see how utterly $\mathrm{C}$ is forgotten for the moment. Of course he will come up again, but for the present he is simply not. 
HAY TO WHITELAW REID.

New York Tribune, N. Y., September 14, 1881.

\section{MY DEAR REID :}

I am glad to hear from you once in a while, and the long intervals only serve to convince me that you are having too good a time to bother about writing letters. Enjoy every moment of the time, for it will never eome back again, and though you are, I trust, to have many long years of married happiness, you will never have the first year over again. Mrs. $H-$ and I are very anxious to go to Europe next year, but we hardly dare promise ourselves that we will go, because of the three small people whom we cannot leave behind, and to take whom will be a constant source of anxiety.

I am getting on so far towards the end of my interimity that I am comparatively easy about the rest of it. I do not see that I have made any serious mistakes. $\mathrm{T}$ - W- paid me the high compliment the other day of saying that he was a little afraid at first I would not know the State well enough, but that he had long ago forgotten that I was not a New Yorker. Of 
course the credit of it is mostly due to the staffbut I have paid great attention and killed a good deal of matter which might have been embarrassing. I have as far as possible steered clear of rows without making the paper seem feeble. If it had been my paper I would have taken the hide off two or three blackguards-but I didn't want to commit you to new quarrels. If G-lives, I think you will find the paper in excellent position, when you return, to give it any direction you see fit. That has been my special object for the last half of my time.

HAY TO ALBERT RHODES.

Cleveland, O., February 19, 1882.

DEAR RHODES :

Many thanks for sending Serge Panine. I should have written to ask for it, if it had not come. I am just now alité by an attack of Diphtheria which will soon be over, I am told; and then we shall attack $M$. Panine.

I have read all the stories in Halévy's volume and find them delicious. I suppose he is Jew by 
religion as well as by blood; otherwise his irreverence would never be so light and dainty.

Yours sincerely, John Hay.

HAY TO HOWELLS.

Cleveland, March 26, 1882.

DEAR HOWELLS:

Your letter had a powerful effect on Mrs. $\mathrm{H}-$ and me. Our minds were in solution and your letter precipitated them in an eye-twinkle. We had been intending to go to Europe, but thereafter all was vague;-now we shall go to Florence. What larks! We shall sail in the $\mathrm{W}$ - S_ steamer of July 15; if you took the same it would be-butter upon sausage as Josh Billings once said in an inspired moment. I have been working hard, and laying up great store of Ms. I shall go down to Washington next week and talk with $\mathrm{N}$ - and then be free,-for a vacation of respectable size.

. . . I I never promised myself that much of a spree in my life. I feel a little superstitious about it now-as if it were too good for the likes of me. 
But to escape the envy of the Gods I will take a lot of historical notes in my trunk, ostensibly to write a few chapters but really to ballast me, and lower my spirits with the thought of duty unperformed.

... I I am still not well, and the Doctor tells me not to be worried if I take a month more to get well in.

\section{Man nennt das grösste Glück auf Erden}

Gesund zu sein ;

Sein grösseres ist gesund

$\mathrm{Zu}$ werden.

When I see you I will tell you what I think of it.

HAY TO STEDMAN.

Cleveland, O., June 28, 1882.

MY DEAR STEDMAN :

Mrs. H- has put a heavy load on me-in charging me to ask you to write some verses in her book. I know, better than most of the profane, what a corvée this is. But I begin myself to wish to see the book completed, and you are too important a victim to escape. You will see how worthy 
the company is of you :-Emerson, Longfellow and others. Don't damn me too much,-say about half what I deserve.

To complete your kindness and fill up the measure of my imprudence-would you mind giving me a letter to S- ? I will not crowd upon him but if ever I come in his way, I would like to be indebted to you for an introduction to him.... We sail from New York July 15. . .

\section{HAY TO HOWELLS.}

Acton Park, Wrexham, September 18, 1882.

MY DEAR HOWELLS :

Did you learn what A- T- would ask, say, for one of those pretty little pictures of his, the one with two figures in it. If it were not too monstrous I think I would get Mr. S- to buy it. Do not take the trouble to ask anybody about it if you have not heard. I want also to impress upon your mind that if you ever make another bargain with an English publisher, you must talk guineas, not dollars, nor pounds. He will accept 
your numerals just as quick in guineas, and you will gain some six dollars in a hundred by it. It is the custom among artists and men of letters, so do not lower the standard.

Saturday last we drove from this lovely place (a seventeenth century house in which the vile Judge Jeffreys was born, now the seat of a family of baronets the most amiable conceivable) to Hawarden Castle, the residence of the Prime Minister. We were disappointed in not seeing the Grand Old Man who was detained in London by a cabinet council; but Mrs. G- was at home and very gracious. I say all this merely as an introduction to the weighty fact that I saw on the drawing-room table a much-thumbed copy of $A$ Foregone Conclusion, and the Prime Ministress authorised and requested me to say to you how much she liked it. We went to-day to visit Chirk Castle, a grand old pile of the date of the thirteenth century, still in perfect preservation and always continuously inhabited since it was built. It was a royal appanage until Elizabeth's time, who sold it to the family who now live in it. This is the first thing of the sort I have ever seen except Warwick, and this is in many respects far finer. . . . . 
HAY TO HOWELLS.

Hotel Beau Site, Cannes,

December 20, 1882.

MY DEAR HOWELLS :

... After I wrote you in Paris I saw some doctors who told me without collusion that if I would stay in Paris forty days and take douche baths I would be well. They were both great swells and the coincidence of their views rather struck me. I remembered also that it took exactly the same time in Noah's day, to cure the world of most of its infirmities by the same method; and so, like an ass, I gave up, or rather postponed, my trip to the South, and went through my douches with, of course, no result whatever. I went back to my doctors and reported. One said :- " Better stop your douches! go to Cannes and amuse yourself! You will soon be all right. Forty francs! thank you! good bye!"

The other said:- "Eh bien! instead of six weeks, take three months of douches. Take them in Cannes, if you like, or in Nice," and with that he gave me an entire change of drugs;- "Forty francs! thank you! bon voyage!" There was nothing Noachian about three months, so I came away determined to do nothing he told me. . . . 
P. S. After shutting my letter I looked at Harper's Christmas, and found naturellement, that your farce was the pearl of the collection. It made me laugh audibly which is mucho decir. I would give money to see it on the stage. There is a little woman at the Vaudeville who played in Tête de Linotte, who would be the best Mrs. Roberts on earth. But it would be impossible here, as a French sleeping car is a sad parody on our glorious institution. It has no sociableness, no promiscuity, no chance for move or war.

By the way, how $J-$ is catching it for his "Point of View!" In vain I say to the Howling Patriot: "The point of view is clearly and avowedly the point of view of a corrupted mother and daughter, spoiled by Europe; of a filthy, immoral Frenchman; of a dull, well-meaning Englishman!" But they respond :- " Miss Sturdy is J_L himself;" and as she says children are uproarious in America, and women's voices are higher than their manners, there is no forgiveness for the writer. The worst thing in our time about American taste is the way it treats J-. I believe he would not be read in America at all if it were not for his European vogue. If he lived in $\mathrm{C}$ - he could write what he likes, but because 
he finds L- more agreeable, he is the prey of all the patriotisms. Of all vices I hold patriotism the worst when it meddles with matters of taste.

HAY TO ALBERT RHODES.

Cannes, January 6, 1883.

MY DEAR RHODES :

Thanks for your letter and your good wishes. I hope this year may cure us both of all megrims and duck-fits.

The sunshine of Cannes is an active joy, whether it has any therapeutic effect or not. I never saw so beautiful a sky and so picturesque a sea-shore as this is.

Mrs. $\mathrm{H}-$ sends her kind regards and the children are all well and gay. The baby is three years old to-day and there are rumors of great doings in the nursery. A cake with three candles and an orgie with sirop.

$\mathrm{I}$, too, have a letter from $\mathrm{P}$ - His glory is not satisfying to his soul. He seems disconsolate.

Where, my brethren, is happiness?

In the dictionary.

Yours truly. 
HAY TO NICOLAY.

Paris, March 8, 1883.

MY DEAR NICOLAY :

. . . I have been so inert and lifeless since I came over here that I have not written a letter except on the stimulus of receiving one. I have never been so idle in my life. It was of set purpose, and I think it has been wholesome.

To give you in a word our itinerary :-We arrived in England the end of last July; spent a few weeks in London, and then went north; saw Lincoln, York, Edinburg, and Aberdeen; then went to visit a Baronet in the Highlands named Sir J_ C__ passed a delightful week with him, then went to the shore of the Northern Ocean at Inverness. Thence down the Caledonian Canal to Oban, Staffa and Iona. Then back to Hastings where we had left the children during all these philanderings. We went up to London again after that; went to North Wales to visit another Baronet and M. P., Sir R- C- At his house we met the Judge Advocate General in Gladstone's Government, Mr. O- - MI. P., who invited us to visit him, which we did, 
and passed a pleasant day or two in an InigoJones house in the mountains of Wales. Then we went on a regular debauch of English Cathedrals:-Hereford, Worcester, Gloster, Wells and Salisbury ; and after that, we broke for Hastings again ; and after a week of rest by the summer sea we gathered up the whole caboodle and went over to Paris.

I was still rather miserable and at last went to two Doctors, $\mathrm{W}-\mathrm{B}-$, an American Egyptian, and the famous $\mathrm{C} \longrightarrow$, the same day. They both advised the same thing, douche baths, tonics and bromides. I followed their prescriptions pretty faithfully, off and on, until now. In December we went to Cannes with the children, and that has been our home all the winter,-and a delicious place it is,-eternal June with an air loaded with orange blossoms. We made our little tour through Provence:-Nimes, Arles, Aiguesmortes, Pont du Gard,-and a longer trip to Florence and Siena, where we met $\mathrm{H}$ -

I am, I think, considerably better, though I have given up all hope of being twenty-one again. We sail for home on the 10th of May in the $G-$, and I hope to get to work immediately, or as soon as practicable after that. I saw the 
Comte de $\mathrm{P}$ — at Cannes and he asked me to give you his Royal compliments.

Thanks for the scrap. King did not write Democracy, nor did I.

\section{HAY TO HOWELLS.}

Cleveland, Ohio, July 27, 1883.

MY DEAR HOWELLS :

I am so much under the weather that I can indulge myself writing on my back,-not that my hide has been tanned for parchment as you use in Massachusetts, - and with a pencil to bid you welcome home..... I have just finished this month's instalment of $A$ Woman's Reason. It is incomparably good. You satisfy absolutely both W—'s and J_'s definition (vide J_'s Daudet); you do entertain, and you do represent life. How admirable J-'s article is-though too generously laudatory; L'Evangéliste, which he so greatly criticizes, seems to me a dismal failure, like the running of a drugged horse.

On the whole, what a splendid number of the $C$ this is! The $\mathrm{C}$ - story ${ }^{1}$ does not please

${ }^{1}$ The Breadwinners. 
me in print as much as I had hoped. There is a good deal of conjecture about the authorship here. Some attribute it to me. Of course, no one in my own intimacy does so. I think I shall be able to keep our friend's incognito intact.

I have been very miserable for a week or two, unable to walk, with that obscure malady which inspires contempt and rage in every doctor I have seen. I have no pain and no interruption of any function, but I cannot walk ten rods; am as drunk as a lord all the time without hilarity or fun. As soon as I get on my feet again I shall write to ask you to come out here to see me. I can give you absolute quiet, the control of your own time, and when you want it a day of trout fishing in a wonderful stream I have recently bought an interest in.

Do you remember the address of Miss $\mathrm{A}-$ in the Piazza Sta Maria Novella? I would like to write to her and ask her for a drawing. Do you think she would do one for me for five hundred francs, or has the rapturous screaming of Ruskin put her out of reach? Did I ever tell you that $\mathrm{C}-\mathrm{K} \longrightarrow$ visited Ruskin at Brantwood and mashed him, as he did everybody? The old prophet took him to his heart and poured lyric toffey all over him.... . 
HAY TO HENRY JAMES.

Cleveland, August 11, 1883.

MY DEAR JAMES :

When $\mathrm{I}$ was in $\mathrm{F}-\mathrm{L} \longrightarrow \mathrm{M} \longrightarrow$ made for me a very admirable bronze medallion of Howells, and I write now to beg that if you find yourself soon in $\mathrm{F}$ _ again you will let him have a shy at your head also for me. I have written to him about it. It will give you almost no annoyance at all, as he works with great swiftness in such things, and if he succeeds with you as well as he did with $\mathrm{H} \longrightarrow$, the portrait will do you no discredit and will be a great ornament to my house.

I am nearly through my year's hard work, and am to start in a day or two with $\mathrm{N}$ - to the Rocky Mountains for a few weeks' idleness.

I greatly enjoyed your Daudet in the $C$ though demurring a little at your undue generosity. Your palinode was excessive, I thought. He is a "great little writer." The Evangiliste is dreary, the work of a genius smitten with locomotor ataxia; (if I had known that word was so long, I should never have begun upon it). There is no coördination in it. Besides, a man who is 
such an idiot morally, can never set down at meat with Shakespeare and you fellows....

\section{HAY TO MR. A- S-}

\section{Paris, March 11th, 1883.}

DEAR MR. S- :

I am very glad to hear of your continued improvement in health and hope when we return in May to find you completely reëstablished. I suppose you have before this gotten my letter of February 24th from $\mathrm{C}-$ announcing our return and so need say no more on that subject. I am getting a little anxious about our stay in Paris, it promises to be longer than I wished or expected, and that of course will lessen our stay in London, which I had counted upon.

The weather is cold, damp and disagreeable. There is a feeling of deep distrust and anxiety in the public mind. A demonstration took place day before yesterday on the Esplanade des Invalides which might easily have become very serious. A few bakers' shops were pillaged and a crazy creature named "Louise Michel" tried to get the mob to march on the Elysée Palace, but the cuiras- 
siers came on the ground and dispersed them. Another riot was feared for to-day, and the streets are full of soldiers riding in every direction. Commerce is in a great state of prostration. The laborers have had the mischief put into their heads by trades-unions, etc., and the consequence is that cheap merchandise is coming in in a flood from Germany and underselling the French on their own ground. Then the politicians in the Assembly are so eager for their individual advancement that no government lasts more than a few weeks and a painful impression of uncertainty has thus grown up throughout France.

What a ridiculous caricature in civil service reform is the appointment of a roaring demagogue like $\mathrm{T}$ - to execute the law.

$\mathrm{H}-$ is eight years old to-day. She has learned a good deal in the past year. She reads very well and has begun to write and knows a good deal of French. D- is half a head taller than she and is getting along pretty well in his studies also. They are all lively, but have eaught little colds in this harsh and damp air. Paris is a poor place to live in. 
HAY TO MR. A- S-.

London, May 2d, 1883.

DEAR MR. S- :

I wrote you a day or two ago, but as I have just returned yours of the 13 th I write once more to express my sympathy with your sufferings and my deep regret that your convalescence is so long delayed. I shall still hope that the warmer weather will be beneficial to you and that we shall find you on our arrival well on the way towards recovery. You have had a hard and distressing winter and spring. It seems very hard that one who like yourself has spent his life in doing good to others, should now be placed in a position where nobody can do you any good.

I have been reading the life of Carlyle, and the other day I walked down to the little house where he lived and died and near which his statue now stands in bronze. At your age he suffered precisely as you do, deep, nervous depression, persistent indigestion and loss of sleep-a general disaster and irritation of the entire nervous system. His misery seems to have been of the keenest character. Yet he lived to be eighty-six 
years of age, and the last twenty-five years of his life were comparatively healthy and free from pain. I met the other day at dinner an old gentleman named $\mathrm{H}-$, eighty-two years old. He told me that between sixty and sixty-five his digestion seemed hopelessly impaired. He could eat and drink nothing and slept very little. Now he dines out every night and is the gayest of the company wherever he is. I rely on your strong constitution, your sober and moral life, the reserve of vitality you have about you, to wear out all your present troubles and to bring you to a healthy and happy condition again. You have so much to live for to enjoy the results of the good you have done and to continue your career of usefulness and honor.

Yours affectionately.

HAY TO HOWELLS.

In the Clouds, Rocky Mountains, Colorado, Sept. 9, 1883.

MY DEAR HOWELLS :

.... I have a letter from $\mathrm{M}-$ the same day as yours. He is going to take $\mathrm{H}-\mathrm{J}-$ his 
head for me the first chance he gets. Yours arrived in $\mathrm{C}$ _ the night before I came away. It is magnificent,-one of the strongest characterised medallions I ever saw. Mine-I laid away tenderly in a closet. I have no vocation for having my portrait taken in any shape.

$\mathrm{N}$ — and $\mathrm{I}$ are in camp in a most beautiful and rugged eyrie 9,000 feet high, sometimes called Crystal Park, not far from Manitou Springs, which is our P. O. address. If you were here-but some day you will come,-I am looking about for a place to build a hut, which I hope you will share with me. The bigness of the beauty of the place is something I am not able to describe and shall not try. I came away from $\mathrm{C}-$ pretty wretched and am already a good deal better. I will come earlier next year and stay longer. I expect to be here at least a fortnight more. . . . .

HAY TO R. W. GILDER.

Cleveland, O., December 29, 1883. DEAR GILDER :

Mrs. $\mathrm{H} \longrightarrow \mathrm{A} \longrightarrow$ has made a remarkable photograph of George Bancroft in his study. He 
is now eighty-three, and one of these days will be gone. I suggest that you get a copy of it and put it in the hand of your engraver-in time. It would fill about a page of the $C-$ put sideways.

\section{HAY TO ROBERT LINCOLN.}

\section{Cleveland, O., January 27th, 1884.}

DEAR B- :

$\mathrm{N}$ - tells me he has laid before you or is about to do so, the first volumes of our history containing the chapters in which I have described the first forty years of your father's life.

I need not tell you that every line has been written in a spirit of reverence and regard. Still you may find here and there words or sentences which do not suit you. I write now to request that you will read with a pencil in your hand and strike out everything to which you object. I will adopt your view in all cases whether I agree with it or not, but I cannot help hoping you will find nothing objectionable. I do not think I have told you we have a new boy-baby, born Christmas time. 
I hope you and yours are all well. Give my regards to Mrs. L- in which Mrs. Hjoins me-and believe me always.

Faithfully yours.

\section{HAY TO HOWELLS.}

\section{Cleveland, O., September 16, 1884.}

DEAR HOWELLS:

I am disgusted! I was very anxious to see you, and was putting out one day for Louisburg Square, when I met a fellow who told me you were somewhere up the Connecticut River. Even $\mathrm{F}$ - W - told me you were to be at Lnear $\mathrm{B}-\mathrm{O} \longrightarrow$ and $\mathrm{F}-$ are equally guilty of suppressio veri. The whole hub conspired to shoo me away from you. I did hear you had bought a house on Beacon Street, and drove by it one day, - not knowing the number, however,-to rejoice in your prosperity.

I have come back, not particularly better, but inclined to grin and bear it. All my people are well. $\mathrm{K}-$ did not come back with me, but has just now arrived and is staying at the $\mathrm{B}-$ 
House in New York, leaving the entire Chamber of Peers in mourning. ...

We are very busy trying to elect B-. I do not know how you feel about it. I met no $\mathrm{B}$ - man anywhere in the East. Those I saw were so furious at my $\mathrm{M}$ - friend that they bandaged their eyes as to $\mathrm{C}$ - and his following, which does not seem to me wise. I did not intend to do anything but pay my subscription, but I was caught the day I got home, and made to preside at the biggest meeting I ever saw in the Square the other night. It now looks to us favorable to $\mathrm{B}-\ldots$. . .

President $\mathrm{H} \longrightarrow$ lunched with me the day I got home; he is hearty in his support of $\mathrm{B}-$, though they have never been friends.

\section{HAY TO ALBERT RHODES,}

MY DEAR RHODES :

Cleveland, Feb. 14, 1885.

Your book arrived in due course of mail and I have enjoyed reading it very much. It is extremely pleasant and entertaining and is evidently written out of a fulness of knowledge of the sub- 
ject exceedingly rare in any foreigner. Indeed, it would be hard for a Frenchman to see himself so clearly, as you with your friendly eyes, have seen him. I congratulate you on having deserved a great success and I hope you will attain it.

It is hard to say anything about official prospects. The new President has put himself so clamorously on the record in favor of retaining good public servants that you would seem to be safe in your place and sure of promotion, if any faith were to be put in princes. I imagine he thinks he intends to act according to his professions, but he has a lot of friends to take care of, and a frightful pressure awaits him after the fourth of March. If he had sense enough to know the things that pertain to his peace, he would not make a single removal-but would do as Ahas done, gobble all the vacancies for his particular friends and talk reform at every gobble. This the people always like and applaud. I almost hope he won't have sense enough to do this-but I do hope he will keep his paws off you, and I see no reason why he should not. A great deal depends on who is Sec. State-which is, up to date, unknown, though it is thought $\mathrm{B}-$ will take it. 
We are all pretty well. I have a new boy, a few weeks old - and he is a "rustler," and oblige me by bearing it in mind.

\section{HAY TO HOWELLS.}

Cleveland, April 2, 1885.

MY DEAR HOWELLS :

.... Yes! I have read Pepita Jimenez. I liked it, but hardly so much as you and $\mathrm{K}-$ and Mrs. A do. So I conclude the fault is in me. I know $\mathrm{V}-$ a little. He seems to me a dull Spanish Academician.

But, Lord love you! the man that wrote Silas Lapham is the man for my money. Mrs. H read me the last instalment a few evenings ago, and what with my admiration of the art of it, and my profound sympathy with Silas, I was so wrought up that I felt as if I had gone into company too fine for me, and got drunk myself. It is awfully good. I am only seized with a terror as to how you are going to keep it up on this level. But, of course, you know what you are about, and it will be a tremendous success. . . . 
HAY TO ROBERT LINCOLN.

Cleveland, O., April 20th, 1885.

DEAR B- :

Yours of the 17 th received. I will do what you suggest in final revision. It is better, even as a matter of taste and without regard to your wishes which would, of course, be conclusive.

The $\mathrm{D}-\mathrm{B}-$ matter shall be carefully looked into. My principal reliance is the tradition in the K. family of W—, who are of the W

$\mathrm{B}-$ kindred. I do not think your great-grandmother was B__'s sister as Mr. W__ did, but I am still inclined to believe there was a connection. But all this must be carefully reviewed.

The only question about going to press is whether we shall wait until we are virtually through or not. We could print three volumes now if thought advisable. All the publishing houses in the country want it.

Yours sincerely. 
HAY TO NICOLAY.

Cleveland, O., Aug. 10th, 1885.

DEAR NICOLAY :

I have just received your letters of the 7 th and Sth. I herewith return the G-correspondence. There will be no difficulty whatever in beginning the series-if ever-next fall (1886). The only contingency in which we should not be able to keep up would be death. If we live we can do it. The reason why I wanted you to criticize the chapters with the greatest severity is this-I dictated every word of it. I found myself breaking down with the nervous fatigue of writing and copying. I therefore had a stenographer. I always thought I could not dictate-but I found the only way was to take time and not hurry, to go back-cross, start fresh, just as if I was writing and not much faster. It is a vast gain. After he writes out the notes $I$ go all over them again with great care. As to your criticisms, you can put in all the things you think lacking, or make a note, and I will do it next fall, strike out or reduce to footnotes whatever you think superfluous. Do this without hesitation and I will do the same with you. An outside judgment on these points is 
almost sure to be right. As to my tone towards P. and McC.- that is an important matter. I have toiled and labored through the chapter over him (McC.). I think I have left the impression of his mutinous imbecility, and I have done it in a perfectly courteous manner. Only in $\mathrm{H}-$ 's L_ have I used a single injurious adjective. The $\mathrm{P}$ - business is a part of this. $\mathrm{P}$

was the most magnificent soldier in the Army of the Potomac, ruined by his devotion to $\mathrm{McC}$ We have this to consider. We are all alone in condemning him. I don't count J-I_L as company for historians. Even P-, who takes the hide off $\mathrm{McC} \longrightarrow$, speaks of “ $\mathrm{P} \longrightarrow$ _'s perfect vindication at the hands of the Board." A big majority of the American people, all the Democrats, all the mugwumps, which means all the literary folks, all the Southerners and half the Republicans of the north. We believe him guilty! but I don't think we need go further than say so dispassionately. G- was evidently horrified at your saying that L_ ought to be shot-a simple truth of law and equity. I find after a careful reading of a dozen biographies and all his own reports that $\mathrm{S}$ ___ was a howling crank. He is a "saint and a hero," Gen'l B- 
said so in a speech the other day. The war has gone by. It is twenty years ago. Our book is to be read by people who cannot remember anything about it. We must not show to the public in the attitude of two old dotards fighting over again the politics of their youth. I confess I learned something by the criticisms of your book. All the reviews acknowledge the merit of style, accuracy and readableness, but nearly every one objects to its tone of aggressive northernism. This was a surprise to me. I read it in ms. and found it perfectly fair and candid-but I am of that age and imbued with all its prejudices. We must not write a stump speech, Eight vols., 8vo. We will not fall in with the present tone of blubbering sentiment, of course. But we ought to write the history of those times like two everlasting angels who know everything, judge everything, tell the truth about everything and don't care a twang of our harps about one side or the other. There will be one exception. We are Lincoln men all through. But in other little matters, let us look at men as insects and not blame the black beetle because he is not a grasshopper. S. P. C. is going to be a nut to crack, so is $\mathrm{S}-$. 
HAY TO GILDER.

Cleveland, O., Aug. 13, 1885.

DEAR GILDER :

I return the Ms. I see no reason for not printing it. I am filled with amazement when I see such things. Here is a fellow-historian who accounts for every second of a week or so, twenty years ago, and I can't remember him, or his name, or say whether I wrote that letter or not.

Can you remember things? I have to rely exclusively on documents. I would not trust my recollection in the slightest matter of historical interest-yet every newspaper is full of long stories, in the utmost detail, telling us all about the great men and deeds of the past. I, who knew them all, have not a word to say.

I have to go to New York about the 9th of September. If it would suit you and $\mathrm{N}-$ to meet me there that day, I am yours to abuse. But if you and he can't come so far south-(you went further when you - but we wander,)-I might manage to go to $\mathrm{B}-$, a day or two earlier or a day or two later than that date. Consult with him and command me, as soon as you make up your alleged mind. 
I congratulate you with all my heart on the splendid success of your Magazine. I thought the July Number the finest single Number of any Magazine yet issued in this wicked world. Daudet's article and your Sonnet were equally delicious and perfectly in harmony; and J-'s poem, Doves in the Calendar, was charming; and Mrs. G_-'s little picture above it was exquisite.

\section{HAY TO GILDER.}

Cleveland, O., Nov. 21, 1885.

MY DEAR GILDER :

Mark this address! We left Cushing's Block ages ago, in the dim morning of Time! It is now a gigantic haberdashery.

I am working like a Turk, in an agony of condensation. If we were Methusalems, and publishers kind, we should make a thousand volumes; I believe I literally reject nine-tenths of my material. 
HAY TO ADAMS.

The Brunswick, New York, Dec. 9, 1885.

MY DEAR HENRY :

I hoped all day yesterday and this morning to hear from you, and thought it possible you might summon $\mathrm{K}-$ and me to be with you at the last. $\quad$ But I suppose you had already gone north when I sent my despatch. I return to $\mathrm{C}$ to-night.

I can neither talk to you nor keep silent. The darkness in which you walk has its shadow for me also. You and your wife were more to me than any other two. I came to Washington because you were there. And now this goodly fellowship is broken up forever. I cannot force on a man like you the commonplaces of condolence. In the presence of a sorrow like yours it is little for your friends to say they love you and sympathize with you-but it is all anybody can say. Everything else is mere words.

Is it any consolation to remember her as she was? that bright, intrepid spirit, that keen, fine

${ }^{1}$ The funeral of Mrs. Adams. 
intellect, that lofty scorn of all that was mean, that social charm which made your house such a one as Washington never knew before, and made hundreds of people love her as much as they admired her. No, that makes it all so much harder to bear.

We are anxious about you. Tell us, when you can, how it is with you. You have a great sorrow, but no man should bear sorrow better than you.

HAY TO NICOLAY.

Cleveland, O., Dec. 11th, 1885.

MY DEAR NICOLAY:

I was in New York for only a few hours and if you wrote to me there I presume your letter will follow me home to-day.

From your letter to Mr. R_ S- I infer you have betaken yourself to work as the greatest panacea for all sorrow, and I presume you will therefore not object to a word or two of business from me. I have blocked out and nearly completed eight chapters entitled as follows : - . . .

I am as yet very much troubled and annoyed 
by the delays about my house-they assured me in October that they would be through in three or four weeks, but from all I can hear there has been very little progress made since then. The lamentable death of Mrs. A- is also a subject of much distress and depression to both Mrs. $\mathrm{H}-$ and myself, and taken in connection with the horrible disaster which has smitten your household, it gives us a promise of a very gloomy winter. The moment I ascertain when we can get into the house I will let you know. I am becoming every day more and more conscious of the great disadvantage of working so far apart from each other and am using all possible means to hurry the architect and builder.

\section{HAY TO ROBERT LINCOLN.}

Cleveland, O., Jan. 6th, 1886.

MY DEAR B- :

I was very sorry to see by a letter you wrote to $\mathrm{N}$ - the other day that you were still not satisfied with my assurance that I would make those first chapters all right. Even before you 
read them I had struck out of my own copy here nearly everything you objected to and had written $\mathrm{N}$ - to make the changes in his which he had not time to do. Since then I have gone over the whole thing twice again, reading every line so far as possible from your point of view, and I don't think there is a word left in it that would displease you. But of course before final publication I shall give you another hack at it, with plenary blue pencil powers.

I do not know that $\mathrm{N}-$ has told you what $\mathrm{G}$ - of the $\mathrm{C}-\mathrm{Co}$. thinks of the work. He is an accomplished critic and the only person on whom we have tried it. He is enormously struck with the whole thing-says Lincoln was a veiled statue before this to him and to the world, that "even if we died now, and left the book as it is, it would still be the most historical work of the time," and etc., etc. I say this not to blow our trumpet, but because I hope it will please you to think the long toil has not been thrown away. We have been making great progress for the last year or two-the book is nearly two-thirds finished. We have finished the fifth volume and are well on in the sixth. If we live two years more, we shall get through. I am more anxious 
than I can tell you to live that long. There has been so much irresponsible and untrue writing of late years, that I feel a solemn sort of pressure in me to do my part-to putting the truth before the country. Year after year of study has shown me more clearly than ever how infinitely greater your father was than anybody about him, greater than ever we imagined while he lived. There is nothing to explain or apologize for, from beginning to end. $\mathrm{He}$ is the one unapproachably great figure of a great epoch.

I am not well, but by coddling myself manage to do a day's work every day.

\section{HAY TO WHITELAW REID.}

Cleveland, O., June 29, 1886.

DEAR REID :

I inclose a letter from Mark Twain which contains a message that $I$ suppose no man can refuse to deliver. I make, of course, no suggestion. Please return it.

I have been reading "Ohio in the War" a good deal lately. It is a splendid piece of work, full of vigor of thought and style. I can do 
nothing of that sort now; I wonder if you could. If so, you ought to be about it. Leave a book, written in that manner, to your children. I am incapable of doing anything but put facts together without a word of ornament or fancy. And speaking of facts, may Heaven forgive you for the way you treated them in your Eulogy of old $\mathrm{R}$

\section{HAY TO GILDER.}

Cleveland, O., Sept. 17, 1886.

DEAR MR. GILDER :

The murder trial which Mr. E- has used in his story is the same as that briefly referred to in my "New Salem" chapter. It was the son of Jack Armstrong whom Lincoln saved from the gallows partly by the introduction of an almanac. The matter is fully treated in $L-$, p. 328. I think entirely too much importance is given to it. L__ credits Lincoln with a dishonest, pettifogging trick by which he secured the acquittal of Armstrong; but the evidence which he presents in a foot-note flatly contradicts his own injurious theory. I did not think the incident worth the 
time and space which L- gave it. As Dr. $\mathrm{E}$ - is to use it, I am all the more glad I did not.

.... The Jefferson Davis matter has been thoroughly investigated. There is nothing on file in the State Records of Illinois, and nothing at the War Department, which goes to prove he mustered Lincoln into service. I cannot imagine how the tradition originated. There is, of course, a bare possibility that he, being on furlough, happened to be present at the moment, and performed this duty, but there is nothing to prove it. I wrote directly to him about it, but he did not answer my letter. We have a very full and satisfactory letter from Gen'l D—, AdjutantGeneral of the Army, which I have used as a note, at the same time incorporating in the text all the essential facts.

I see nothing incorrect in the sentence you send me from your December editorial. The fact is true and the inference is not violent.

We shall, before we get through, probably write a descriptive chapter about Lincoln in the White House. 


\section{HAY TO GILDER.}

Cleveland, O., Oct. 22, 1886.

DEAR GILDER :

.... On galley 39 you will find a phrase "mopped the floor with him." When I first heard it, years ago, it seemed very racy. Since then it has got to be a regular bit of newspaper slang. If it has grown banal to your ear, strike it out. . . .

Your sonnet on the Mask seems finer every time I read it. It is nearer the heart of the matter than anything I have said. But that is what a poet is for.

$\mathrm{I}$ suppose $\mathrm{La} \mathrm{F}-$ and $\mathrm{A}-$ are on their way East from San Francisco by this time. They have had cholera in Japan and lots of fun.

HAY TO GILDER.

Dec. 10, 1886.

DEAR GILDER :

Thanks for the Lincoln chestnuts!

I did not see the $E-P \longrightarrow$ in the December instalment-but would like to, if convenient. 
I enclose a letter from the historical expert of the same Theological Seminary-a swell pundit. Please return it to me.

I am very glad indeed if you are not disappointed in your subscriptions. I was afraid the public was getting tired of the whole thing, war politics,-war articles,-etc. The Good Man knows I am!

HAY TO R. W. GILDER.

800 Sixteenth Street,

La Fayette Square, March 7, 1887.

DEAR GILDER :

$\mathrm{N}$ - has handed me your letter of the $3 \mathrm{~d}$. We have a good deal to say about the subject you mention. The stories are mostly untrue, but there are some things of especial interest. Barnes (Memoirs of Thurlow Weed, p. 428) gives the old gentleman's account of a transaction which he greatly exaggerated in conversation in his old age.

The simple fact is that Lincoln would gladly have given way to anybody who he thought could do more for peace and union than he 
could;-but we have never been able to find that he actually made definite overtures to anyone, further than these stories of Weed.

HAY TO DR. WEIR MITCHELL.

800 16th Street,

Washington, D. C.,

March 29th, 1887.

DEAR DR. MITCHELL:

I received "Sylvian" ${ }^{1}$ to-day and have spent several delightful hours over the book. It is a new fountain of feeling and melody opened at a time when I was beginning to think everything of the kind was drying up. The songs are charming-they are so young and ardent, full of fire and dew. And I was delighted also with the selections from "The Fawn" (is not that a misprint for Faun?). I hope we shall have the pleasure of reading the whole of that poem one day. It is astonishing in its breadth and breeziness. I greatly like too the "opening of an unfinished poem." It ought not to remain

I "Sylvian" was a volume of poems written by the son of Dr. Mitchell, Mr. Langdon Mitchell. 
unfinished. I beg you will give your son a handshake of God-speed from me at this auspicious opening of what I doubt not will be a splendid career. I thank you cordially for introducing me to this vigorous young book, and am always, Faithfully yours.

\section{HAY TO GILDER.}

Cleveland, O., April 25, 1887.

DEAR GILDER.

The only question is whether you want the Life to run three years or four. If the former, you must take heroic measures. Leaving out a chapter here and there, or retrenching an adjective, will do no good. You must cut great chunks of topics out. For instance, $\mathrm{N}$ - says if you want to leave out the history of the opening of the rebellion, there are twenty-six chapters between the election and the inauguration of Lincoln which can be left out, and only the intelligent reader, if such a being exists, will miss them. Then there are in all some dozen long chapters of the war in the West, absolutely essential in the history, which can be cut down to a paragraph in the Magazine. 
But it ought to be settled beforehand whether or not you intend to make these serious abridgments. Neither $\mathrm{N}$ - nor I can write the work over again for the purpose of saving a half chapter, here and there. You have his full consent, and mine, to leave out as much as you like, but we cannot shorten up a chapter to any extent by rewriting.

This is in the nature of a caveat. If you hereafter tell us the infernal thing is too long, we will sweetly answer, "I told you so."

\section{HAY TO ADAMS.}

Cleveland, May 12, 1887.

MY DEAR $\mathrm{H} \longrightarrow$ :

.... I thank you for your kind word about my verses. They are not fresh, but have been kicking about the place for twelve years. There will be no fresh ones-once in a decade I may fish out an old one and have the pleasure of hearing a friendly critic say what progress they exhibit, and of hearing some scorpion contemporary hiss that I am falling into dotage.

$\mathrm{K}$ - has come to the surface again in San 
Francisco,-the $\mathrm{P}$ - Hotel,-whence he writes me that he will be detained a month on the slope. I expect to hear next that he has lit out for the scene of the earthquakes to locate a section on the auriferous veins which have been flung into view. But-on second thought-here is his letter! Please keep it for me, or send it back here. We are in $\mathrm{C}$ - for a fortnight more. One by one, our offspring have come down with measles. I went last week to visit my mother, leaving two of them in bloom, with an imbecile hope that the rest might escape; but I got back last night to find the baby in flagrant efflorescence, and this morning $\mathrm{D}$ — looks like an Italian sunset. So I gave up my passage for the 18th and have been wiring all day to-day to try to get something for the 1st of June. If possible we shall sail that day. I have a pleasant letter from $\mathrm{R}-\mathrm{C}-$ asking us all to Acton for the last of May-which of course we cannot do-and sending his love to you. ...

My mind is a chaos of measles and disappointment,-and this too shall pass away! 
HAY TO SIR JOHN CLARK.

Cleveland, May 14, 1887.

DEAR SIR J- :

Your cordial and cheery letter came a fortnight ago and would have been answered at once, had we not been in a twittering state of uncertainty about our plans until this moment. We hurried home from Washington to make our annual station here, earlier than usual, so that we might sail in the steamer of May 18th. But our eldest girl Hcame out in a rosy glory of measles soon after we got here, and we had to wait for developments among the rest of the brood. With exasperating deliberation they all followed, at the longest possible intervals, until now that $\mathrm{H}-$ is convalescent and $\mathrm{A}-$ is arriving at the hopeful illtempered stage, the baby is as red as a lobster and the older boy flames like a sunset from the Pincian. But we hope we know the worst, and having given up our ship of the 18 th we have taken rooms for the 1st of June, on the G-, which ought to put us into London on the 10th.

I am very grateful for your advice about lodgings. I engaged rooms six months ago at the $\mathrm{A}-$ Hotel, which was very strongly recom- 
mended to me by W-. (Did you ever happen to meet him? handsome fellow with a charming wife), and I have cabled them to still hold the rooms for us. But I shall keep the addresses of the places you mention and they may be useful in case of trouble with the $\mathrm{A}$ -

It is annoying to be so delayed. Our summer was to be a short one at best, and we can ill afford to have so large a bit of it sliced off the June end of it. But there will be some pictures to see and some shop windows to stare at; and by going away I can at least escape my friends the critics, and the veteran statesmen, who know they saved the country and think me a miscreant for not saying so.

I wish I could promise that $\mathrm{K}$ - would come with us. He has been darting like a meteor through Mexico and is now in San Francisco superintending the building of works for his $\mathrm{S}$ - mines. He has been very ill this winter, but there seems to be great recuperative forces somewhere about him always, and he gets out of bed for a ramble of five thousand miles and thinks nothing about it. Once in a great while he gives us a day - never more than that - in Washington, and then there is a Jubilee among 
the Four of Hearts-even the vacant chair seems less gloomy when he is there. $\mathrm{He}$ is planning vast historical works, but the pen and he are in strained relations. A- is drawing near to close his great work, The $U-S-$ from 1800 to 1816 . It is, in my impartial opinion, the best piece of writing this generation will see from the hand of a Yankee. He hopes to finish writing this year, and after a year or two of revision and proof-reading he says he is going for several years to China. $\mathrm{He}$ is up to his eyes in Chinese art, history and geography, and proposes to leave Marco Polo out of sight in his travels and explorations.

I hope, in a fortnight after you receive this letter, to report to you from London, and we shall consider our little outing a failure unless we see you and Lady C_- We shall-after a few weeks in London, plant the babies in some healthy spot on the coast-we think of Folkstone-and then go gypsying away and try to make believe we are still young and charming.

Mrs. $\mathrm{H} \longrightarrow$ sends her love to Lady $\mathrm{C}-$, and I am always,

Faithfully yours. 
HAY TO R. W. GILDER.

Cleveland, O., May 14, 1887.

DEAR MR. G- :

"Why, certainly!" I sail with my whole caravan, for England on the 1st of June, to return in September. Grace aiding me, I shall do nothing all summer, except to masticate the lotus. I shall look at some pictures, eat some gooseberry tarts, cross some channels, thank Heaven I am not some Frenchmen, and try in all possible ways to forget that my evil star set me upon writing history. I shall have my $C$ sent after me, and shall hope that Mrs. Gand you are enjoying the summer as you deserve for making such a good paper.

HAY TO WHITELAW REID.

Cleveland, O., May 25, 1887.

DEAR REID :

.. . If I knew what day I should arrive in New York, I should try to make a rendezvous with you. I hope I may get away from here Friday or Saturday, in which case I will wire to 
make an appointment for a little talk, if possible on Sunday, but I am not sure. Tuesday I am engaged for dinner, and Wednesday we sail on the $G$ - Did you ever hear of such good fortune as we have had-so far?

We were to sail on the $B-$, May 18. $\mathrm{H}$ - came down with the measles, and the rest of the family followed suit with such deliberation that the $B-$ had to sail without us,-whereby we escaped the affair with the $C$ and the return to New York. But what was the special good luck, we found at the last moment that the same rooms we gave up on the $B-$ had just been given up on the $G-$, and we now have them for the 1st of June.

We were very sorry not to see Mrs. $\mathrm{R}-$ as she passed through, but we were living in so dense an atmosphere of measles that, although we do not believe in the transmission of infection by third parties, we chose not to disquiet a young mother by presenting ourselves at such a time. ... 


\section{HAY TO ADAMS.}

\section{London, June 15, 1887.}

MY DEAR ADAMS :

It has been a dull series of days since we parted on that crowded dock. Our fellow-passengers were, like ourselves, hardly worth mentioning. Mrs. H— suffered; so did $\mathrm{H}-$, though she soon regained her equilibrium and flew over the deck like a petrel. $\mathrm{D}-$ and $\mathrm{A}-$ and $\mathrm{I}$, and, but for one dubious day, the Baby, retained our health and what little senses heaven has blest us withal.

... The town is an intolerable nuisance with the preparations for the 21st. The streets are clogged with stands,- the Clubs are dismantled so as to be all windows,-I just saw several houses in Piccadilly with walls pierced to afford a better view. It pays to do it. H-'s Hotel has rented its windows at sixty guineas each. There is hardly a house on the line of march but will pay its year's rent by its windows in an hour.

We have seen few people as yet and do not expect to see many. I dine with the Lord Mayor 
Saturday-see what it is to be good and virtuous! I have not as yet come across any of your cronies. ... .

They asked me at $\mathrm{P} \longrightarrow$ 's if $\mathrm{K}-$ was still in the Cabinet.

HAY TO SIR JOHN CLARK.

$$
\text { London, June 16, } 1887 .
$$

DEAR SIR J- :

We are at last safely arrived at the haven where we would be. We have not the rooms which we engaged six months ago, as the Queen of the Sandwich Islands wanted them, and as all your effete monarchies stand by each other, they were taken from us and handed over to her chocolate-colored Majesty. We yielded gracefully, since we would have been sent to the Tower if we had not done so-and meekly trotted up higher. The dark lady gives your Queen no end of trouble, I hear, insisting on all possible rations of mint and anise in the way of precedence-so that your royal family begin to wish her 
back in her salubrious island home. The town is clean daft over the Jubilee. I scoffed at it for a day or two, but my wife and children at last sat upon me and directed me to find them a window from which to see the show. I did so, but had to pay roundly in guineas for the time I had wasted in scoffing. Most of the houses on the line of march will recoup their year's rent out of the hire of their windows for an hour. But all this you read in the daily papers.

When may we come to $\mathrm{T}$ - and greet you? We can come either in July or August. Any day you may fix during July or the last third of August will be gratefully accepted by us, and we will make all our plans to correspond with that. We shall keep the children here for a few weeks to do their Baedeker business and then plant them for a month out of harm's way at the seaside-F_ probably-while we go on our devious ways. We had hoped to have $\mathrm{K}$ with us and we miss him sorely; he is building a great stamp mill for his problematical Mexican mine, and he half promises to be here in a month, but of course he will not.

Mrs. $\mathrm{H}-$ sends her love to Lady $\mathrm{C}-$ and we both look forward with uncommon pleasure to 
the prospect of breathing once more a deep draught of your Highland Air, and of renewing under your liberal roof the friendship we so sacredly prize.

Yours faithfully.

HAY TO ADAMS.

Tillypronie, Aberdeenshire, July 20, 1887.

MY DEAR H- :

I got your letter the other day in London just as we were flitting from that jubilating and tiresome town. We planted the babies in the sand and shingle at $\mathrm{F}-$ and then went off to the $\mathrm{F}-\mathrm{s}$ in Surrey. Thence we came north by slow degrees; whenever we came in sight of a cathedral tower we stopped the train and got off and dined and slept. Thus we did at Ely, and Norwich and York and finally at Edinburg. After that, we went to A- C_— in Perthshire, who is keeping his honeymoon-having just married a pretty girl-in the sensiblest manner imaginable, by never allowing an opportunity for an hour's tête- 
à-tête from one week's end to another. The house is thronged with visitors-sixteen when we came away,-we merely stayed three days, the others were there for a fortnight. Among them were your friends $\mathrm{B}-$ and $\mathrm{H}-$ of Maine. $\mathrm{C}$-_ likes it so well he is going to do it every summer, and is looking at all the great estates in the County with a view of renting or purchasing. We went with him one day to Dupplin Castle, where I saw the most beautiful trees I ever beheld in my wandering life. The old Earl of $\mathrm{K}$ - is miserably poor-not able to buy a bottle of Seltzer,-with an estate worth millions in the hands of his creditors, and sure to be sold one of these days to some enterprising Yankee or British button maker. I wish you or C_- would buy it. I would visit you frequently.

I find the $\mathrm{C}-\mathrm{s}$ remarkably well and very cheery. They have much to say of you and we drop in a remark occasionally to keep the thing going. ... 
HAY TO NICOLAY.

London, Aug. 4, 1887.

DEAR NICOLAY :

Here is a letter I received to-day, forwarded from Cleveland. I hope it may soothe a little the sensibility lacerated by $\mathrm{S}-\mathrm{J}-$ You might even take note of a line of it, but that is hardly worth while. I have been passing the idlest summer of my life, my principal business being to avoid thinking of my work-and to get back if possible in a frame of mind suitable to the homestretch. I have heard a good many civilities about the book, though everybody kindly tells me it is too long and they candidly damn the pictures. But we are not writing for Europeans. F$\mathrm{U}-$, the English publisher of the $C-$, called on me and I took the trouble to return his call. He thought he was making himself agreeable by telling me what desperate work he had pushing the Magazine and how little interest was felt in it! I only called once. We stayed in London till the first week in July and took in the Jubilee festivities, which were about what might have been expected and at least amused the children-then we planted them at the seaside and went a round 
of country visits in Surrey, Scotland and North Wales. We returned here yesterday for only a day. To-morrow we go to the Isle of Wight for a few days, then to the Cornish Coast and back to London for the last half of August.

HAY TO SIR JOHN CLARK.

$$
\begin{aligned}
& \text { Ryde, Isle of Wight, } \\
& \text { August 7, } 1887 .
\end{aligned}
$$

DEAR SIR J- :

It is not $\mathrm{T}$ - It has not the keen exhilaration of your Dee-side air, and above all we lack the comfortable company of that mountain Eyrie. But to travellers bent on making the best of everything-even this sheltered island, lying in the lap of a hot and glassy sea, is not without its charm. We drove yesterday-though that is too much of a phrase-we went on top of an excursion coach to Carisbrook Castle, and spent an hour or two most agreeably in that fine ruin, and coming back had from the top of the downs, the fairest view possible of this pretty domain, over which the flag of Osborne waves paramount. Next week the place will be intolerable with 
yachtsmen and their admirers. We shall quit the island, and do some more cathedral towns, to wit, Winchester and Canterbury and Rochester, and so drift back to London where we are due on the 13th at $\mathrm{T}$ - his hotel in B- Square.

Our journey has varied most ingloriously from the fine plans we sketched in your energetic air. Mrs. H- has, I think, given you our route to A- Park. There we stayed from Saturday until Wednesday. There was no company except on Monday, Mr. and Mrs. C- (she was a daughter of Lord L-) and Sir $\mathrm{R} \longrightarrow$ and Lady E-. But we had a delightful visit. We went one day to tea at the $\mathrm{L}-\mathrm{s}$ of $\mathrm{C}-$, one of those exquisite Cheshire black and white houses, which you know all about,-early sixteenth century; and the day before we came away the $\mathrm{C}-\mathrm{s}$ went with us to the Manchester Exhibition,- - the finest collection of the British Art of the last fifty years I fancy ever got together. In fact, it is hard to imagine anything more complete. A- has covered himself with glory. It makes one tremble to think what a fire would do there. No insurance company would take the risk, and the gentlemen of Manchester have done it-at, I forget how many millions. The $\mathrm{C}-\mathrm{S}$ 
are well and cheery in spite of dry weather and politics, both of which make them groan occasionally. The triumphant election of $\mathrm{T}$ - was dampening to $\mathrm{C} \longrightarrow$ 's genial spirit,-although he is too kindly and too inherently candid ever to be cantankerous over anything. He has very little hope about $\mathrm{N}$ _ ; but is going on the stump for Lord H. G_- By the way, I take it for granted you have read Lord $\mathrm{H} \longrightarrow$ 's last speech at the Greenwich dinner. It looks like a final farewell to the Liberal party, and a full espousal of the Conservative.

We found our two older children at London well and happy and ragged as tramps. Mrs. $\mathrm{H}-$ shod and clothed them and after a pleasant dinner with $\mathrm{H}-\mathrm{J}-$, whom we had commanded to dine with us at $\mathrm{B}-$ and who was in good looks and good spirits and full of new schemes of work-we came down here on Friday night. We are going to Ventnor tomorrow.

The $\mathrm{W}$ — S - people write me that they will take the Dog, and that she should arrive in Liverpool on the 6 th of September (the $G$ sails at noon of the $7 \mathrm{th}$ ) and should be consigned to the care of the Butcher of the ship. This is 
a sanguinary suggestion, but I believe it is all right. I enclose a cheque on Barings for enough I hope to pay for shipping the cherished Beastie to Liverpool, and have arranged for her carriage after she arrives there. If there is anything over give it, with my blessing to McK- or the good woman who cared for the infant dogs.

I have left myself no room for expression to you and Lady C- our gratification for the charming visit and all your continual kindness to us ward-but you know we are affectionately and gratefully yours. The visits are too short and the intervals too long. We do not know how we have had the luck at an age when one rests content with the friends one has, to meet new friends dearer than those of our youth.

Yours faithfully.

HAY TO WHITELAW REID.

$$
\text { Ryde, Isle of Wight, }
$$

August 6, 1887.

MY DEAR REID :

I have passed two-thirds of my vacation without sending you a word, and if I were to wait until 
I had something worth communicating I should come home without writing. At all events it is too late for you to answer this letter; so you can't waste much time over it.

I have never in my life been so absolutely idle. The Jubilee occupied the first two or three weeks. $\mathrm{S}$-_'s admirable despatches gave you a better idea of what took place than if you had seen it yourself. The town was intolerable as long as the fuss lasted-and after all there was not much to see but a lot of Kings. I felt that in justice to my posterity I must take a room in Piccadilly - at a year's rent-to see the procession of Royalties go by-and was fortunate enough to be able to offer hospitality to the $\mathrm{P}$ __ ladies and $\mathrm{M}-\mathrm{B}-$, but having done this I had seen them enough. Everybody who was rushing madly after them to twenty different functions regarded us as heathen for neglecting such precious opportunities.

B - had a very good time in London. $\mathrm{S}$ ___ gave all his time to him and you know his great range of acquaintance. I was myself amazed at the ignorance of English people about B__ ; many of them had positively never heard of him; those who had said they understood he was 
the candidate of the Irish and the spoilsman against the Reform Element. One meek little man, son of the famous Dr. P-, who had not detected my American accent, said at a tea party "I hear he is the greatest blackguard of the lot." I dealt with him in a spirit of love, until he sneaked out of the room, and afterwards sent a letter of apology to the lady of the house, saying he did not know what he was talking about. Everybody who met $\mathrm{B}$ — seem taken with him except $\mathrm{C} \longrightarrow$ and $\mathrm{R} \longrightarrow \mathrm{C} \longrightarrow$. They both spoke ill of him afterwards. I dared not tell $\mathrm{B}-$ this ; he seemed to think kindly of both of them and to think they reciprocated his feeling.

We spent a day or two with $\mathrm{A}-\mathrm{C}-$ at his rented place at Perthshire. The $\mathrm{B} \longrightarrow \mathrm{s}$ and $\mathrm{H} \longrightarrow \mathrm{s}-$ the $\mathrm{I} \longrightarrow \mathrm{s}$ and $\mathrm{C}-\mathrm{P}-\mathrm{s}$ were there also. A big houseful for the little bride to manage. Did you ever meet her? She is a very sweet and winning young woman. The A-s were there to dinner one day and we had the pleasure of talking about you and Mrs. R-

We have had two or three agreeable country visits-one in Surrey; one in Wales and one in Aberdeenshire. Some of the old residences in Scotland are extremely interesting. You ought 
to take a summer sometime and breathe your ancestral air. Everything in the kingdom is for sale or rent. For less than the hire of a Newport Villa you can get a palace with thousands of acres of shooting and fishing. I hope you are by this time perfectly recovered from all your besetments. We stay in London till about September 1st, sail for home on the 7 th.

Yours faithfully.

HAY TO SIR JOHN CLARK.

London, August 23, 1887.

DEAR SIR J- :

Will you kindly get this letter to G-, first reading it yourself. I hope we can do well by him, better than I have said, but I never like to promise more than a minimum. If he feels like coming he may start at any moment. I will wire notice to the man who is there.

We are giving the children their final instalments of London sights. Saturday Mrs. Hand I went down to Worcestershire to visit some Yankee artist friends of ours, who have leased a 
queer old house at Broadway where they live in great content and paint eighteenth century subjects. They are Mr. and Mrs. F- Mand $\mathrm{E}-\mathrm{A}-$, delightful folk of the genuine Yankee type. They are even worthy of knowing you. If I ever find you both in London I will set them before you.

The lost prospect of meeting $\mathrm{P}-\mathrm{F}-$ at your house fills us with mingled pleasure and pain. We feel as if we had a sort of acquaintance with him subjectively-and shall read of him hereafter with greater interest than ever.

$\mathrm{B}$ - has been good enough to get me an order for the House of Commons next Thursday, when I hope to sit from 3 to 3 munching chocolate caramels to keep me from starving, while I listen to the great debate on the Proclamation of the League.

The $\mathrm{Y}-\mathrm{T}-\mathrm{s}$ are coming to dine with us to-night. He naturally feels rather cocky over his Cross and Longworthy exploits-so we will have to sit on him a little in reference to his $\mathrm{S}$ fiasco. We had $\mathrm{J}$ for an evening last week-he has had poor S- on his handsshipped him to America yesterday morning, I suppose, half dead, on the steamer Ludgate Hill. 
$\mathrm{He}$ goes to Boston-S- does-and if he escapes alive out of the lionizing which will attack him there, he will go to Colorado for the winter. It is a shame that so much genius must depend for its earthly lodging on so rickety a body. There ought to be such a thing as transfusion of genius. Thanks to Lady Cfor her delightful letters.

Yours faithfully.

HAY TO E. C. STEDMAN.

New York, Aug. 13, 1887.

MY DEAR STEDMAN :

Thanks for the paper! They also sent me one. You are like lots of others. We-I will put myself in also-adore freedom; but we don't want anybody to make free with us.

The reason, I imagine, is this, I have never met a reformer who had not the heart of a tyrant. Boundless conceit and moral selfishness seem the necessary baggage of the professional lover of liberty.

Many of us think we are radicals when we are 
merely Epicureans. However, catching bass is nobler than moralising.

P. S. Miss $\mathrm{H}-$ has this instant shown me your letter. Whittier's praise doubles your triumph at Concord. It was a noble poem and will be best appreciated by the noblest minds.

\section{HAY TO ADAMS.}

London, August 25, 1887.

DEAR A- :

Yours of the 4th came the other day, and with it two long and expensive letters from the $\mathrm{K}$ at $\mathrm{S}-$, full of comparative gynaecology, and not containing a word about the land purchase. The letters, qua letters, were charming, and I suppose I will know when I- sends me my bill whether we have bought the land or not. $\mathrm{K}$ - is in delicious vein-he ought to write his novel now.

We have our little London all to ourselves at present. A diligent search reveals only the $\mathrm{Y}-\mathrm{T}-\mathrm{S}, \mathrm{S}-$ and $\mathrm{J}-$ Yes! Bstill lingers. His sisters have preceded him to Switzerland, whither he expects to go this week. 
But the debate on the Proclamation of the League has detained him. He has given me an order for the House to-day, and I am going for the first and last time in my life, to put in the whole day and night there. It is a corvée that everyone should submit to once.

$\mathrm{J}$ _ comes in to dinner occasionally and is remunerative. He has quite recovered from his Venetian jaundice. Mrs. H- and I spent last Sunday with the $\mathrm{M}-\mathrm{s}$ and $\mathrm{A}-$ at Broadway, their place in Worcestershire. We saw some of the prettiest country we have ever come across, and the establishment wore an air of decency and intelligence which was extremely agreeable. $\mathrm{M}-$ is painting two pictures which promise well, and A- is at work on his first oil painting. $\mathrm{He}$ is in the stage of cold fit, and says it is " getting ilier and ilier."

I bought at the $\mathrm{R}$ - sale a nice lot of Old Mastery drawings-which I tard to show you. I have also spent the last cent I got for " $\mathrm{D}$ in minerals for Mrs. $\mathrm{H}$

After we left the $\mathrm{C}-\mathrm{S}$ we took the two older shrimps and went down to Isle of Wight. We found the neighborhood of Cowes so infested with princes and such vermin that we went down to 
the south coast, and found Brading, Sandown and Ventnor extremely pretty and soothing. There are lots of pretty things in this rickety old planet, if we could only have the enterprise to look for them and the nerves to enjoy them. But-eheu fugaces-I ought to have done my enjoying while the day lasted.

We expect to be in New York on the 17th September. Then I hurry to C- - put my affairs into disorder-and scoot down to Wat the earliest possible moment. I hope I may meet you there, though if you go to Mexico I shall be content for your and $\mathrm{K}$ - 's sake, dismal as W- will be without you. I shall work like a yeast plant this winter-not because I feel like it but because I hate it, and because I feel that my time is waning.

My wife and children send their loves. The children bid me tell you they have a little collie pup;- - they know you will be glad to hear it. 
HAY TO ADAMS.

\author{
The Brunswick, \\ New York, Sept. 18, 1887.
}

PHILOSOPHER AND FRIEND:

We arrived here on time Friday morning, and after three hours' wrestle with the Customs, we came, faint but victorious, from the struggle, not to say smuggle, to this snug harbor, where we found your note of welcome and felt at home.

$\mathrm{K}$ - turned up in due time and we have had two days of gossip with that notorious malefactor. $\mathrm{He}$ talks of starting west Monday (to-morrow) and bearing us company as far as $\mathrm{C}$ - Of course he will not, but I have engaged a section for him. I am dallying with the idea of going to Mexico with you. It would be criminal, but that only makes it the more tempting. My wife says I may go and " if any other women go," she swears "she will not be left out." We both feel we need rest and recreation after our arduous summer drinking tea with them there Kings. I will talk it over with Childe Clarence.

I congratulate you on your new volume, though it makes me sick with envy. I have not done 
an hour's work-nor has $\mathrm{N}-$, except proofreading, which has whitened his few remaining hairs.

\section{HAY TO ADAMS.}

Cleveland, Sept. 23, 1887.

MY DEAR ADAMS :

I can't go to Mexico. I wanted so much to go that for a day in New York I weakly imagined I might. But I had not been in Cleveland two hours when I saw it was not possible. I have at least six weeks of work to do here and in $\mathrm{C}$ before I can relapse into history, and I must finish my first draught this winter. There is a Woe upon me if I fail to do this.

I am miserable along of Mexico. I feel that it will be with that goodly land as it was with Japan,-not going with you I shall never go. I shall clear up my affairs here, however, so as to be in Washington when you return, and shall then haunt you unmercifully in all unhistorical hours. ... 


\section{HAY TO ADAMS.}

Cleveland, Nov. 7, 1887.

MY OWN NEXT-DOOR NEIGHBOR :

I had fondly hoped to be with you to-morrowbut the world has beaten me. I doubt if I shall start before next Tuesday, the 15th, but on that day I come through every tile on the housetops.

I had a season of sweet refreshment with J$\mathrm{S}$ _ the other day. He says there is no dear property in Washington; it is cheap at any price. He does not believe in suburban property. I agree with him. Neither of us owns any.

I pine to see your tea-garden. If I have the luck to win my bets on $\mathrm{F}-$, I will buy the ground that marches with yours. We will sell roses next June, on the spot, and make New York Avenue the fashionable quarter.

$\mathrm{K}-$ is, I learn, alive, and has been in Mexico. I have tried to open up communications with him, but he treats me with the silent contempt I deserve. . . . 
HAY TO W. L. STONE.

Washington, November 14, 1887.

DEAR STONE :

I thank you for the de Trobriand review. I did not know the old General had so correct a notion of $\mathrm{McC} \longrightarrow$. If another Frenchmanthe Comte de $\mathrm{P} \longrightarrow$, to wit, - had seen as straight as de Trobriand, we should not have so much trouble in uprooting the false legend.

We shall touch the subject you refer to-but there is, after all, not much to say. There was no better man ready to put in his place. Band $\mathrm{H}-$ you know both failed in succession after we had got rid of him.

HAY TO MRS. S-

800 Sixteenth Street,

Lafayette Square, Washington, December 7, 1887.

DEAR MRS. S- :

I have often wondered what was the meaning of that figure of a cock on a drum which I 
brought you from London and which occurs, very often in Japanese art. The other day I bought a piece of embroidery at $\mathrm{V}-$ 's - the same subject. A Japanese gentleman named $\mathrm{O}-$ was in our house last week and I asked him the meaning of it, and I have thought his answer might interest you.

He said the drum in the picture was one which in old times stood outside of courts of justice. If a judge was corrupt or prejudiced and did injustice to anyone, the injured party had the right to beat this drum and call the people together and protest against the treatment he had received and demand that the case be heard again before all the neighborhood. To put a chicken on the drum and represent all the fowls in the place peacefully feeding around it, indicated that the drum was never used for the purpose mentioned, and that consequently the courts were pure and upright.

Mr. A — brought us some very beautiful things from Japan, in the way of porcelains, lacquer work, etc., which I hope you will soon see.

We have been suffering a terrible blizzard here for two or three days. The snow is now about a foot deep and still falling. We have all taken 
colds, and are not bragging so much as usual about the lovely Washington climate.

The baby is beginning to talk a little, though he is very slow about it. $\mathrm{He}$ is very active and energetic and has to be constantly watched to keep him out of mischief.

I have begun my writing work and have completed a chapter. I shall hope to keep steadily at it if my health lasts.

Yours affectionately.

HAY TO WHITELAW REID.

Washington, Dec. 8, 1887.

DEAI: REID :

That is a magnificent document you print to-day. What a tremendous contrast between the penny-cracker of the man inside, and the roar as of great guns, from the man outside. If brains were votes, how easy our battle would be?

I am coming up to New York one day next week and shall try to see you.

$\mathrm{W}$ — has made charming portraits of the children. 
HAY TO. HON. W. M. EVARTS.

\section{Sixteenth Street, Lafayette Square, Feb. 6, 1888.}

DEAR MR. EVARTS.

Victor Hugo used to say that a man of seventy was younger than a man of sixty-nine-because while the latter date was the old age of youth, the former was the youth of old age. But my mention of old age seems irrelevant to such a vert-galant as you are. In honor of the day, however, I send you a book of a respectable maturity-and when you have been in the world as many years as this volume, we may begin to ask you how you enjoy growing old.

To-morrow, also, is full of tender association to me as it is the birthday of my father and $m y$ mother.

Mrs. H- joins me in the most affectionate good wishes for you and Mrs. E-, and I remain always.

Faithfully yours. 
HAY TO ROBERT LINCOLN.

800 Sixteenth Street,

Lafayette Square,

Washington, March 5th, 1888.

DEAR B- :

Thank you for the corrections-all of which I have of course adopted. The Ms. of all the articles goes to the publisher to-day. I was sorry to bother you but $I$ thought it best in every way to consult you-and it was.

I am much gratified at what you tell me about Mr. L_; he has after all said the best things about your father-but that's what a poet is for.

We get thus far very little abuse and most of that is clearly motives.

Yours faithfully.

You may notice that we do not give the name of the pioneer A— L_'s wife. The reason for this is we have it on positive authority from collateral relations that her name was $\mathrm{M}$ $\mathrm{S}-$, that her name was $\mathrm{H}-\mathrm{W}-$ and that her name was $\mathrm{B}-\mathrm{L}-$ We shall take a long breath and consider before adopting either of these positive statements. These Vir- 
ginia-Kentucky pedigrees are puzzles. I don't know the baptismal name or birthplace of my G. G. mother. I take it for granted you don't remember.

\section{HAY TO WHITELAW REID.}

Washington, March 14, 1888.

MY DEAR REID :

I got up this morning intent on my duty. I lost my trunk yesterday. It went careering off towards the Pole, on a train that I left in a hurry, hearing it could not get beyond Wilmington. But I packed a bag of second-best things and went once more to the Station this morning,for it grieved me to lose my visit. They would not sell any New York tickets, and they kindly but firmly assured me that twenty-four hours would be mighty good time between here and New York. I came back sorrowful-for I have a bad larynx, and to start in this weather on an arctic expedition, not knowing when I shall arrive anywhere, would not be merely silly-I do silly things every day-but positively young, and I do young things no more. 
So give my humble duty and undying regrets to Mrs. R_- I shall never get even for losing your Thursday evening.

As to my poor wife, I wot not what has become of her. She and my little $\mathrm{H}$ - left here Monday morning. Yesterday morning she telegraphed from Philadelphia that there was no immediate prospect of getting to New York. And last night another telegram came from the city of Brotherly Love,-but in neither did she say where she was. I have been firing into the Philadelphia woods, but do not yet know whether I have hit her or not. I do not know which of $\mathrm{B}-\mathrm{R}-$ 's ships she is like, the Lands of Snow or the Lands of Sun one,-and I am a sadly mixed community.

\section{HAY TO WHITELAW REID.}

Washington, March 16, 1888.

DEAR REID :

I went to the station every day till to-day and was told there was no probability of getting through. Yesterday, as it appears, I might have got to New York at midnight. I am very 
sorry to have missed your party. My ms. went on, I suppose, and is now at the Station. After vigorous telegraphing, I have as yet no news of my trunk.

I am engaged here for a week or two, finishing up some important matters, but shall go to New York about Easter. But meantime is there no light on the situation? If $\mathrm{B}-$ is irrevocably out, what is the matter with $\mathrm{S}$ -

There are three questions :-

1. Who is the man to get votes and be elected?

2. Who is the man to make a good President?

3. Who, beaten, will leave the party in best shape?

It seems to me $\mathrm{S}-$ is the best possible man for the last two points. His lack of magnetism, his lack of following, would be worth millions in the Presidency, if he were elected. $\mathrm{He}$ is thoroughly fit for power. Then, if we must be beaten, $\mathrm{S}-$ is the best possible man to be beaten with. It won't hurt the party much, and won't hurt him at all.

The first point is the great one for a nominating Convention. You know more about that than I can. If you went in for him he could be nominated. Could he be elected? 
Mrs. H_ made a gallant effort to get to New York. She got through to Philadelphia Monday, and there abode Tuesday and Wednesday. On Thursday, seeing no chance of more than one day in the week in New York, she came back, arriving here at eight o'clock. What a visitation we have had,-it would have sounded like pure madness if Wiggins had predicted it. . . .

HAY TO ROBERT LINCOLN.

Washington, D. C.

April 12, 1888.

MY DEAR B- :

I own a few of your father's ms. which he gave me from time to time. As long as you and I live I take it for granted that you will not suspect me of boning them. But to guard against casualties hereafter, I have asked $\mathrm{N}$ — to write you a line saying that $I$ have never had in my possession or custody any of the papers which you entrusted to him.

I have handed over to $\mathrm{N}$ - to be placed among your papers some of those which your father gave me. The rest, which are few in $10^{2}$ 
number, are very precious to me, I shall try to make an heirloom in my family as long as one of my blood exists with money enough to buy a breakfast.

We are nearly at the end of our life-long task and I hope you will think your father's fame has not suffered any wrong at our hands.

Yours sincerely.

HAY TO ADAMS.

Tuxedo Club, May 19, 1888.

MY DEAR HERODOTUS:

Yesterday morning I went to $\mathbf{K}$ - 's office and asked if they had tidings of him. They said he was in Eureka and might be home in a week or a month. I went to the Hotel, and there, in the middle of the shrimps, sat $\mathrm{K}-$. He is not what I could wish. He has the fashionable throat, like myself and the Kaiser, and is much disgusted about it. He has besides, the usual assortment of maladies,-but he looks well and fit.

He refused to come here with us, but says he will start for $\mathrm{S} \longrightarrow$ and the New Hampshire lakes generally, on Thursday morning. 
.. . This is a beautiful place and it makes one happy to think how much money it has cost $\mathrm{P}-\mathrm{L}-$, who being a Democrat and a freetrader is the predestined prey of the righteous. We pass our Sunday here, and Monday go back to the Hotel $\mathrm{B}$ - and then, if $\mathrm{K}$ - is ready, we will go to $\mathrm{S} \longrightarrow$. Give our fondest love to $\mathrm{S}-\mathrm{R}-\ldots$

\section{HAY TO ADAMS.}

Cleveland, May 28, 1888.

MY DEAR ADAMS :

... After Tuxedo we came back to New York, found $\mathrm{K}-(\mathrm{O}$ portent!) ready to start as he had promised, to $\mathrm{S}-$, and thither we went. Ten minutes before we got there, we looked each other in the three faces,-we had been making conversation for an hour to keep from saying the things that beset us,-and all at once we said in chorus :- "We don't want the place!" and each begged pardon of the other for changing our minds. We got off at old D—'s, feeling like murderers, and kept up a ghastly chatter to throw dust in his eyes. He harnessed up his 
machine and took us to see the farm-and lo! we fell in love with it over again. The old fool who owns it, and his wife, a woman good enough for Z $\mathrm{Z}$ - bore down on us and wanted to talk, but we escaped on the 5 o'clock train, went to Boston, slept, and in the morning I wrote to the ancient idiot, offering again to buy,-on harder terms than I have yet offered him. And to tell you the truth, I did not know even then whether I wanted him to take me up or not. To-day I have a wailing letter from him, begging for mercy, which I shall not answer, and next week, I suppose, he will sell me the farm-for about twice its value. If so, we shall build a campooty there next summer.

$\mathrm{I}$ have regretted $\mathrm{W} \longrightarrow$ and you every hour since I left there; though the weather was delightful at Tuxedo, good at Boston, and Elysian at Sunapee.

... The children are well and very grubby from coal-smoke and the garden. I am up to my eyes in the greasy details of money-making and find I am prospering as do the wicked. 
HAY TO NICOLAY.

Cleveland, O., June 11th, 1888.

DEAR $\mathrm{N}-$ :

Here are two letters from angry posterity, that of young $\mathrm{S}-$ is of no consequence. That of $\mathrm{P}-$ is serious and requires a careful answer. As you have studied the matter you might try your hand on a brief reply, not arguing the matter, letting him understand that we are not the inventors of the story he finds distasteful. $\mathrm{I}$ do not see there is anything in $\mathrm{P}$ - 's narrative not mentioned by us, except the fact that $\mathrm{S}-$ on the 12 th of July, answering P_-'s letter of the 9th July, authorized him to go to $\mathrm{C}-$ and told him to threaten J- on Tuesday the 16th. We might bring that in revision, otherwise our story is as straight as a string and cannot be altered. Have you P_'s book? If not I will send it to you. 
HAY TO ADAMS.

Cleveland, June 25, 1888.

MY DEAR ADAMS:

I have got back alive from Chicago and out of the hands of the $\mathrm{G}-\mathrm{s}$. I sat near Miss $\mathrm{R}$ $\mathrm{S}-$ and $\mathrm{W}-\mathrm{B}-$ and Mrs. P- and lifted up my voice in shouts for Uncle John, ${ }^{1}$ but to no avail. Benjamin Harrison got there, and I suppose I must vote for him. I will keep myself up to the task by thinking of Cleveland, and occasionally reading an editorial in the Nation.

$\mathrm{I}$ dined at $\mathrm{F}-\mathrm{McV} \longrightarrow$-'s. The new house ${ }^{2}$ is beautiful beyond words, exquisitely furnished and adequately lived in. The beautiful $\mathrm{H}-$ girls (Mrs. P- P- and Mrs. F- Gwere there; likewise $\mathrm{F}-\mathrm{B}-$ and Mrs. $\mathrm{W}-\mathrm{D}-$ - - so the air was decidedly Manchester-by-the-Sea.

I also gazed with due reverence at the shop of Marshall Field. It is, to use your own elegant phrase, a squealer from Squealersville. I went inside and had speech of the proprietor. I told

${ }^{1}$ Senator John Sherman was candidate for the Presidency at the Chicago Convention.

${ }^{2}$ Designed by H. H. Richardson. 
him it was nip-and-tuck between him and Pittsburg, which had the tidiest house in the country. ${ }^{1}$ $\mathrm{He}$ answered, with the large magnanimity of the West:- "Oh, Pittsburg! Yes, they say it's a daisy!"

HAY TO ADAMS.

Manitou, Colorado. July 14, 1888.

MY DEAR H- :

.. I take note of your criticisms. I have not the Magazine in reach, and do not remember wherein I have sinned. I agree with you about the historical present, and would have sworn I never used it,-except possibly of writing. Do you bar that? May I not say, "Pliny observes," or "McC_— writes under date of — ? ? I share your detestation of "now." In fact I consider it horribly obscene--but I may sometimes have fallen into that crime.

I congratulate you with all my heart on your rapid progress on the home stretch. You will,

${ }^{1}$ The warehouse of Marshall Field at Chicago and the courthouse at Pittsburg were designed by H. H. Richardson. 
after all, get through before we do. Nevertheless, I am glad to lose this summer.

Yesterday the whole tribe went up the mountain-side to my eyrie. A-, who was never on a horse before, made her eight miles with perfect serenity ; coming back, $\mathrm{H}$-_ entered the village at a Buffalo Bill speed, yelling like a cowlady. The place is as beautiful and wild as when it first seduced my verdant eyes. But I feel as if I should never again have the courage to visit it. Don't you want it? I will sell it cheap. I have made so much money this year-by H-'s victory over Uncle John-that I can afford to be generous. ...

I shall be at Manitou for about a month. . . .

HAY TO ADAMS.

Manitou, Colorado. July 30, 1888.

MY DEAR H- :

.. I have been ill to live ever since I came here. I do not know if it be air or water, or age, or total depravity, but for two weeks I have ailed. The medical man thinks I will be better the day 
after to-morrow. $\mathrm{H} \longrightarrow$ and $\mathrm{D}-$ live on horseback; $\mathrm{A} \longrightarrow$, more modestly, inhabits the back of a burro. The Baby has the chicken-pox. He does not like the name, and forces us to call it the Yabbit Pox. He is a loathsome sight, but he, also, will be well après demain.

... Write to me from time to time. I have read "plum through" as they say in this longitude, Boswell's Life of Johnson, and never so clearly realized before what an obscure man he was, lacking the sacro Boswell. A biographer equally ignoble, and writing equally well, would have made a ten times greater man out of $\mathrm{R}-$ C_- Johnson had more Latin, but $\mathrm{C}-$ had more impudence, and all there was of Samuel was Latin and insolence. How do you account for the fact that now-a-days nobody knows any Latin? I know none, but at thirteen I knew more than any of the recent graduates of Yale or Harvard whom I fall in with.

I congratulate you on your speed on the homestretch-and yet it will be a dark day for me and my house that sees you free to start for China. Lafayette Square will be a howling desert without you. 
HAY TO ADAMS.

\section{Manitou, Colorado,}

MY DEAR H-D:

August 23, 1888.

I have your letter of the 19th and am overwhelmed at the fate of the greenhouse. I will not tell the shrimps till to-morrow, when I get them into the inaccessible fastnesses of Crystal Park, where their vocal despair may waste itself unheard of civilization. I could better spare C_- from the White House than your winter garden from Washington. We might start a circus on the lots.

We have just got back from Leadville and the Carbondale country. We did our mine and crossed the Great Divide. We give four days to loafing here, and on the 29th pull out for CThis is to provoke you to come to New York on the 12th of September, dine with $\mathrm{K}-$ and Mrs. $\mathrm{H}-$, (I shall be there), and go to some show. I am sure we need cheering up after the collapse of the conservatory. Besides, a New England clergyman has just written to ask me if the Jesuits got Wilkes Booth to kill Lincoln, and I can't answer a conundrum of that scope without consulting you. 
$\mathrm{F}$ $\mathrm{McV}$ is here. We take walks, and quarrel like cat and dog. If you were here, you and he could worship G- in alternate strophes.

Mrs. $\mathrm{H}-$ sends love. $\mathrm{K}-$ will be heartbroken about missing you. He went to $\mathrm{Q}-$ especially to see you.

\section{HAY TO ADAMS.}

Manitou, August 27, 1888.

MY DEAR ADAMS :

You see how "the villain still pursues me!" Call him off-speak him fair, if in your power. If not, conciliate him with a club, for, verily, I am aweary of his handwriting and of his message. And if $I$ ever join you again in making two elderly millionaires a present of an alley, be ready, Gods, with all your thunderbolts, ... . .

We went up Pike's Peak to-day. The kids were amused. Mrs. H- and I found something to be desired.

We start for home the day after to-morrow. 
HAY TO ADAMS.

Cleveland, O., September 20, 1888.

MY DEAR H- :

I think perhaps it will do no harm to write to $\mathrm{H}-$ about $\mathrm{C}-$ I I invited him to dinner on the ground that it was Saturday, and he would be $\mathrm{d}$ - if he would dine with any d- Republican on a Saturday night. (Such language is shocking from a Mayor!) If you don't believe me, I enclose his letter.

$\mathrm{D}-\mathrm{D}-\mathrm{C}$ has invited me to bring $\mathrm{C}-$ to spend a quiet Sunday, or part of one, at Lloyd's Neck. If you do not come on, I should be inclined to do that. Then $\mathrm{K}-$ or I can take him out to $\mathrm{T}-$, and bore him, gently but firmly, to such an extent that an invitation to $\mathrm{R}$ - will seem like an open gate to Heaven. As soon as you make up your alleged mind whether you will come or not, let me know. The representatives of the criminal classes who are coming to dinner are $\mathrm{S}-\mathrm{B}-, \mathrm{D}-$ $\mathrm{D} \longrightarrow, \mathrm{W} . \mathrm{W} . \mathrm{A} \longrightarrow, \mathrm{W} \longrightarrow \mathrm{R} \longrightarrow, \mathrm{K} \longrightarrow$ of course, and one or two others. Do not come if it is an inconvenience. We can take care of him for a few days well enough. 
I shall give him a dead-head pass at the $\mathrm{B}-$ and make him at home at the $\mathrm{K}-$ and $\mathrm{C}-$ Clubs. I am under considerable obligations to him, and must do what I can, in my own way, to get even. If he kicks, we must explain to him that it is the custom of the country, and that in a Presidential year it would be unwholesome for an Englishman to put on too much side. . . . .

\section{HAY TO ADAMS.}

Cleveland, October 18, 1888.

MY DEAR ADAMS :

I was glad to learn from your Chicago letter that you were still alive and also that you were keeping our esteemed and beloved Bart. up to his work. He must not be allowed to pause for a moment in his career of gaiety. If he once gets out of the shafts, we shall have trouble in getting him back to his former pace. Nothing less than eight dinner-parties a week from now till Christmas will satisfy the reasonable demands of American hospitality.

I shudder to think into what unworthy hands his political education has fallen. After $\mathrm{K}-$ 
and I and Mrs. D- had given him such an excellent start, rising with the lark to wave over him the bloody shirt, and outwatching the Bear to show him the Gospel as it is in B-, it is sad to think of his being left to the malice and incivism of Democrats like you and $\mathrm{McV} \longrightarrow$. I shall have to introduce him to $\mathrm{H}-$ and Mrs. $\mathrm{H}$ _- when he gets back to Washington.

I start in an hour for my Dismal Swamp with canardicide intentions. After a day or two there I come back here and pack for the Capital.

That cook of Mrs. D—'s turns out to be an African man-a sort of Umslopagas with innumerable virtues. But Mrs. H- wants an Aryan woman.

HAY TO E. A. ABBEY.

Lafayette Square, Washington, October 25, 1888.

DEAR ABBEY :

My house is unfinished till I get those drawings of yours. Of course you have forgotten what they are, so I will jog your memory. 
Two drawings from the "Quiet Life."

1. 'The Skittle Players.

2. The Fisherman.

3. The Harvest Home Procession.

4. A picture to be chosen by yourself.

You can't think how much they are needed on my wall. In fact to quote the ingenious $\mathrm{Mr}$. Pears. "I won't be happy till I get them."

If the Shakespeares are for Mammon, you must save me one or two of them.

We passed this summer in the Rocky Mountains, in and about Manitou in Colorado. I never lived so near heaven before-some 10,000 feet above sea-level. As my doctors had warned me against any great altitude, I thought I would try Pike's Peak, (14,000), so we all went up there in a wagon the day before we started for home,-and I remain, as before, like Theodore Winthrop's Frenchman, with "a good heart and a bad stomach."

I want awfully to see you and London once more, and do not as yet know whether I can make it next spring,-though the big book is virtually finished. 
HAY TO JOSEPH B. BISHOP.

$$
\begin{aligned}
& \text { Washington, D. C. } \\
& \text { January 11, } 1889 .
\end{aligned}
$$

MY DEAR BISHOP :

I thank you very much for your kind letter and the enclosures, which I would not otherwise have seen. I thoroughly appreciate a good word spoken for "Jim," who is a friend of mine. I shudder and hide in the cellar only when the boy with the small Knickerbockers is mentioned.

A curious thing happened during that summer when we were holding up the Republican party by the tail.

On the first appearance of J. B., Mark Twain wrote to me, saying that I was all wrong making him an engineer,- - that only a pilot could have done what I represented him as doing. This troubled me somewhat, though I thought I was right. During the summer of '87, a cotton broker of New Orleans, a son of my J. B. (whose name was $\mathrm{O}-\mathrm{F}$ - by the way) came to see me at the Tribune Office, and absolutely confirmed my story, saying that his father was engineer of the "Fashion," and died in just that way. But the case was of course uncommon-the 
pilot usually does the work-and Jim Givens comes again to discredit me.

I am afraid this is ominous of my fate,-to be right as a historian and wrong as an artist.

$\mathrm{I}$ have been reading $\mathrm{B}-$ for the last week and constantly reminded of you. He quotes nearly the whole of your paper before he gets through. ....

\section{HAY TO EDWIN A. ABBEY.}

\section{Sixteenth Street, Washington, January 21, 1889.}

DEAR ABBEY :

Thou wicked and unprofitable Abbey. I give you one more chance for your immortal soul. I believe those drawings of mine have been lost, strayed or stolen. Wherefore I beseech you, instead of them, send me by return packet four other sketches to be chosen at your own discretion.

Your "Old Songs" are lovely. They have been my salvation this Christmas; I have given them to everybody. The Chinese Minister dotes on them.

I see the English papers are talking of you and $11^{2}$ 
$\mathrm{M}-$ and $\mathrm{S}-$ for A. R. A. For whom shall

I pray? If I were an Immortal, I should vote for all three of you. I do not know your betters in any Academy.

But send me my drawings before you grow too smart to recognize my existence.

We have been prisoners for several weeks on account of one of the children having scarlet fever. It is odd to live in a small city like this, and see the world at a distance, and be like a dead man, if dead men could read newspapers-and be as out of it as Julius Cæsar.

Give my love to all good people-such as $\mathrm{P}-$ and $\mathrm{M}-$ and $\mathrm{S}-$ and $\mathrm{B}-$ -

Maybe we will see you next summer.

HAY TO GILDER.

Lafayette Square,

February 5, 1889.

MY DEAR MR. GILDER:

My forebodings were realized yesterday. The Copyright Bill will not pass this Congress. I have little hope of the next. Legislative government has failed in this country. 
HAY TO ROBERT LINCOLN.

\section{Lafayette Square, Washington, D. C., March 27, 1889.}

MY DEAR B- :

I congratulate you most cordially on the great decoration. It is the most conspicuous compliment in the gift of a President, and I am delighted to see it go to you. I have had some inkling of it for several days, but did not dare speak of it till the nomination went to the Senate.

I hope you will retain $\mathrm{H}-\mathrm{W}-$ as Secretary of the Legation. $\mathrm{He}$ and his wife know their England better than any Americans have ever hitherto done, and I am sure they will be of very great use to you. It will not be possible to find anyone offhand who would do the routine and social work so well. Mrs. H joins me in warm congratulations to Mrs. L-. When will you be here? If I can be of any service to you in any way do not hesitate to command me.

Yours faithfully. 
HAY TO NICOLAY.

Knickerbocker Club, N. Y.

April 15, 1889.

MY DEAR NICOLAY:

I told $\mathrm{G}$ - that he could cut and slash all he liked, provided we were to do nothing in the way of rewriting. $\mathrm{He}$ expressed his thanks for the permission, but thought he would not need to avail himself of it. They are all very cheery in the office about the book.

I saw $\mathrm{D}$ - this morning. He was quite curious about the process of collaboration,--said he had read it all thus far, and could see no difference in manner of style. There is a singular proof of the nullity of criticism-coming as it does from one of the first critics of the age. I gave him no satisfaction, but told him I thought no one would be able to say where one left off, and the other began.

Whitman's lecture yesterday was quite interesting as to audience and accessories. The lecture itself is about all in print,--nothing whatever new. 'The $T$ - of this morning, speaking of the lecture, calls Lincoln "this country's greatest President"-without qualification. 
We leave for $\mathrm{C}$ of yourself. There is no need of your taking too much pains. Let me make one suggestion. In preparing for the chapters yet to be written, prepare-as far as possible-so that either of us can do the mere writing, when the time comes, without having to go all over the subject again. If I come back well next fall, I may be able, after finishing those I have allotted to myself, to turn in and lend a hand to yours if you find it then necessary to spare yourself. In that case it would be much easier to deal with a few envelopes than with a library.

HAY TO ADAMS.

London, May 31, 1889.

MY DEAR HENRY :

I am sitting in my overcoat trying to keep the vital spark alive in this shivery climate while you are enjoying the loveliest season of the year. We had the finest weather imaginable coming over-the sea was as smooth and monotonous as a poem by Lewis Morris. By the way, I went to a party the 
other night where the only two human beings I ever saw before were he and Sir Edwin A-, the two competitors for the laurel when it falls from the brow of his Lordship. G- and S- are better than that.

We have had ill-luck in seeing people. Mrs. $\mathrm{C}$ - is at Brown's. We asked her to come and dine with $\mathrm{B}-\mathrm{H}-$, but she was engaged with smart people. We have exchanged pasteboard but no words. We saw her driving in the Park yesterday looking prettier than ever. S$\mathrm{R}$ - has been out of town; he is coming to us next Monday. $\mathrm{R}-\mathrm{C}-$ shipped miladi to Wildbad last night, and is coming to dinner to-night.

Last night $I$ dined at the $W$-'s and sat between Lady $\mathrm{H}-$ and Mrs. Robert Elsmere. She thinks the only American novels worth reading are " $\mathrm{D}$ __ " and the " $\mathrm{B}$ to make her believe I wrote them,-but it was $n$. g. I told her I once made a journey with you and got no profit out of you because you would not lift your nose from Robert Elsmere all the way. I met also Trevelyan, who spoke of you with affection and asked us to visit him in the country. $\mathrm{L}$ _ is established in Cadogan Square and 
seems well enough amused. Everybody is very civil, and if his liver holds out, he will have a good time. The only question people ask me is whether he is a good speaker after dinner. I tell them we can't send them a poet every time. They really feel they have a right to expect a first-class comedian from America-yet they send us W-s and $\mathrm{P}-\mathrm{S}$ and $\mathrm{T}-\mathrm{s}$.

Yesterday in Grosvenor Square I met a tall and graceful maiden who turned out to be La $\mathrm{M}-\mathrm{F}-$ I I walked about the streets with her, and she lost her way talking about you and Washington. Her brother made a speech yesterday in the House of Commons in which he gave warning that Scotland would not stand playing second fiddle forever.

Mrs. C - E - we have missed, but are to dine there some day. Mrs. C- O- is great fun. She married her beauty-daughter this year, and has brought out another.

You see I had nothing to say except that we still love you, and that we are pretty well-barrin' the climate. 
HAY TO ADAMS.

Raith, Kirkcaldy, N. B.

June 11, 1889.

MY DEAR ADAMS :

I heard of your mother's death just as I was leaving London to come here. She had lived long; she had many joys in life; love, honor, troops of friends; she knew the greatest of all happiness to a mother, a family of children, virtuous and distinguished; she had come to the time when life had no further charm to her; and yet I suppose that all these things bring little consolation to you at this hour. I stand so near the same bereavement that I can sympathize with you. But I can say nothing but send you my love, and Mrs. H- charged me with hers as I started.

I could wish you were here. I have rarely seen a place so beautiful. The park gates are near the station, and all the long drive up the hill, the road is bordered with a flame of rhododendrons and azaleas, and the jargoning of the sweetest singing birds I ever heard. There was nobody in the house when I arrived but D- and Mrs. $\mathrm{C}-$, and $\mathrm{M}-$, who was low in her mind 
because it was nine o'clock and broad day. The sun was still glorious above the western horizon. Young $\mathrm{S} \longrightarrow \mathrm{R} \longrightarrow$, the Manitoban, came in to dinner, and late at night, $\mathrm{M}-\mathrm{F}-, \mathrm{B}-$ and $\mathrm{C}-$, an Irish convict, came back from two meetings they had been holding somewhere. It is astonishing, the perennial interest they take over here in their politics.

We go to-day to $\mathrm{D}$ - and to-morrow I must leave to meet Mrs. $\mathrm{H}-$ and the $\mathrm{W} \longrightarrow \mathrm{s}$ at Mrs. D-'s in Warwickshire. I am sorry to quit this lovely spot so soon. The $\mathrm{C} \longrightarrow$ s are well and very happy. They do nothing but eat, sleep and fish. D_L hates London and dinnerparties, but here he is wrapped in measureless content.

HAY TO ADAMS.

London, June 26, 1889.

MY DEAR ADAMS:

Our quiet dinners, our slow evening parties, our tramps through streets and shops, are approaching their close. We flit to Paris next week. The $\mathrm{C} \longrightarrow \mathrm{S}$ are to sail this week. They only heard 
of the old General's illness two days ago. They had been at Novar and other places with $\mathrm{F}$ and had finally taken a castle in Rosshire for the summer, and were just establishing themselves in it, when their summons came.

We dined at Mrs. M F___'s last night and heard all these particulars. It is a pity, for they were enjoying themselves greatly in Scotland. M- has completed their subjugation and they no longer protest at her exigence. Mrs. C_-'s cold was gone and she was looking brighter and prettier than ever. $\mathrm{D}-$ also seemed grumblingly content.

We passed the other day a happy afternoon at Merevale, Mrs. D__'s Warwickshire place. It is one of the prettiest parks I ever saw ; the oaks are very pictorial, and the house is large and well kept, with some excellent pictures. D- kept firing away all day with his new detective camera, and the girls were very happy on grass and flowers.

We took a drive this week on a coach to Dorking. The scenery was very pretty, and I bought out of a roadside garden $\$ 10$ worth of roses for two shillings. I am making my fortune in this country. 
We eatch $\mathrm{S} \longrightarrow \mathrm{R}-$ sometimes and bid him discourse. He is bright and cheery, lives in the Foreign Office and seems to be about his work, like ordinary mortals. $\mathrm{C}-$ is suffering still with hay-fever-so is $\mathrm{S}-$; so is Mrs. ML_- whose pretty eyes and nose deserve a better fate.

What are we doing? Nothing in particular;we dine somewhere every night; we go to a few big jams where we know nobody, and moralize on the passing show. There is another Miss M$\mathrm{F}$ - Miss Edith, who is excessively bright and beats the Punch fellows at caricature. I have seen no art worth talking about except Sargent's Ellen Terry in her beetle's-wing green dress as Lady Macbeth, -an overpowering picture. The Irving-Terry play is magnificent as far as scenery and machinery go-but laisse à désirer comme acting. Still my young people approved it, and that is the principal thing. You will have the divvle's own time with $\mathrm{M}$ - when she gets back. She has learned fifty new and ingenious methods of tyranny which she is burning to put in practice on Dobbitt. $\mathrm{R}-\mathrm{R}-$ and $\mathrm{F}-\mathrm{M}-$ are in town. Don't you wish you were? We lunch with the W-s at Greenwich to-morrow 
and I shall have to swear I adore L- and $\mathrm{S}-\mathrm{J}-$, or he will smash the crockery on my head.

HAY TO ADAMS.

London, August 4, 1889.

DEAR HENRY :

Here we are again, after a month of such idiotic rushing as would have disgraced a Cook's tourist on his 'Oliday. We got such a head of steam on at last that we tore through Belgium and France yesterday, jumping two frontiers and two customhouses, and finally encountering the worst gale of the year in the Channel,-a gale which knocked out the Queen and the Emperor of Germany and postponed the Great Review for two days. And all we have gained by it is a London Sunday--and the frivolous and loquacious $\mathrm{L}$ - to dine with us to-night. He has been offered the Riggs Collection of Armor, worth $\$ 2,000,000$, if Congress will build a shed for it-which I think I see the Hon. Aminidab Chawbakin doing.

I have to stay here a week and let Sir Mrummage my throat; then I go to $\mathrm{T}$ - with 
M and $\mathrm{H}$ and $D$ -the Laird will have it so, unknowing,-A at Canterbury with R_- Later we look in on $\mathrm{T}$ - - in Northumberland if we can make it fit, and finally say good-bye to $\mathrm{R}-\mathrm{C}-$ at Acton before we sail-which we do on the big $\mathrm{W}-\mathrm{S}-$ liner T-, September 4. Lady $\mathrm{C}$ - i is back from Wildbad, somewhat better of her rheumatism but not yet well.

$\mathrm{R}$ — $\mathrm{F}$ - marries Lady $\mathrm{H}-\mathrm{B}-$-, daughter to the Most Noble the Marquis of $\mathrm{D}-$ and $\mathrm{A}-$, on the 29th of this month. He is as gay as a cricket over it, and people say good things of her-as of other daughters of Marquises. She is a lucky girl if they hit it off comfortable, for "R- and $\mathrm{N}-$ - is a thoroughly good fellow,-though there is always to me a touch of comic-pathetic in an aristocrat who thinks he is a radical, sitting gaily on the bough and sawing away at it, between himself and the trunk.

I have nothing to tell you, I think. B- has started a war with England, I read in the $O$ this morning, but this you probably know already. I hope hostilities will not break out in New York harbor before I get home. Perhaps I may have 
to hoof it through Siberia and cross the ice at Behring's Straits. Ask W- to make peace while B-'s back is turned-a nice little peace for a nickel which will last me to $\mathrm{C}-$.

.... I am as anxious to get home and get through as ever I was to take my quinine when I was young, and have done. They send me an occasional column of abuse from some irriend of $\mathrm{McC}$ - or C C - and I can only wonder at the merciful Providence which keeps my critics away from the weak joints in my armor. Laws-amercy! if I had the criticising of that book, what a skinning I could give it! I can't amend it, but I could éreinter it-de la belle manière. There is nothing left but to read proof and get it printed, which will take six months,-and forgotten, which may take six weeks.

Meantime, allow me to congratulate you on the wisdom which keeps you at your task, and away from this dusty, dessicated old continent, which to an idle and infirm man of middle age has little to offer.-There! that is one of the gaucheries which $\mathrm{D} \longrightarrow$ delights in--but I mean myself and not you--and can't rewrite my letter for the blunder. I am out of sorts, and stupid a faire plaisir. 
HAY TO ADAMS.

\section{Tillypronie, Tarland, Aberdeenshire, August 19, 1889.}

MY DEAR ADAMS:

I have nothing in particular to say, except that two ladies, each the most charming of their sex, have at different times this summer commanded me to send you their loves, and I have forgotten it till now, when the sun, rising over the purple moor, rouses me to a sense of duty. They are Miss, the Right Hon. J-_ C- - M. P., and Mrs. L_, whom you knew as Miss D-_.

We have had a very happy week at $\mathrm{T}$ The Laird is very fit, and Lady $\mathrm{C}-$ - though evidently growing weaker, is as cheery and bright as if she were well. The children have been made happy. Every detail of the farm life is delightful to them. They are the intimate friends and confidants of the shepherd, the laundress, the dairy and the grieve. And to crown all his other benefactions, $\mathrm{T}$ - has given them a blond collie to bring home. They seek him at sunrise and part from him with tears at night.

We drove the other day to Balmoral and stood with emotion before the bronze statue, heroical 
size, of John Brown, in the garden. It is inscribed :-

"Friend more than servant, honest, truthful, brave, Self less than duty, even to the grave ;"

these lines being the production of the Most Gracious.

We leave here in a day or two. I spend a day with $\mathrm{T}$ - - - then we loaf down or up to London. My wife finishes her shopping;-we flutter down, a cormorant flock, on $\mathrm{C}-$ for over Sunday, and then go to Liverpool to sail. . . .

\section{HAY TO ADAMS.}

Cleveland, September 21, 1889.

MY DEAR H- :

It was a great sorrow not to see you at Y__'s, but Mrs. H— knew you were in Canada. $\mathrm{K}$ - came, and we thought he was going to $\mathrm{S}$ - Lake with us, but of course he had a most important engagement in Boston the next day, which, also of course, he did not keep, for he wired us a few hours later from Providence.

We had a water-color portrait by Downman, A. 
R. A., which $\mathrm{C} \longrightarrow$ sends you by our hands, and also a little photograph of T-, which, now, you must wait a month or two for.

.... I pine for the sight of you and yet I must not go to $\mathrm{W}$ - for some weeks. There are building plans to settle here and trades to be made and leases to be haggled over, and my mother to be visited, and ducks to be slain and I don't know what, which will keep me till well on in October. It seems a thousand years to wait, especially as I have no real work to occupy my alleged mind.

The Lincoln peters out in January, and then there will only remain the revision and proofreading of the latter half of the impregnable volumes. You will get through first because you are unus sed leo.

The children send their loves. They have much to tell you. $\mathrm{D}$ - resembles in build your revered $\mathrm{G}-\mathrm{C}-$ The baby whistles and sings like a lark. The girls cumber the ground. 


\author{
HAY TO ADAMS.
}

Cleveland, October 11, 1889.

MY DEAR H- :

. . . I I am preparing, with what speed I may, to come to W-. I have been to my mother's -who is eighty-six, and makes me ashamed of myself with her serenity and cheerfulness. I have been to the marsh at W-'s Point shooting ducks. The vital statistics report the ten days I was there as the healthiest for ducks yet recorded. But I enjoyed the open air very much and caught a blooming cold.

\title{
HAY TO WHITELAW REID.
}

Cleveland, October 14, 1889.

MY DEAR REID :

I enclose, at your request, a memorandum saved from the wreck of a fast-failing memory, which you may incorporate in your autobiography with a certainty that it is true. By the way, why don't you imitate your predecessor, $\mathrm{B}-\mathrm{F}-$ and write your memoirs while you are in Paris? But do not print them till $\mathrm{D}-$ is dead, or he 
will say you never were in Paris. He says I was not at the War Department on the night of Lincoln's reëlection, and after I had assured him that I was, he says he consulted with you, and that you agreed with him that I was not there. If this be so, I wonder who the evil-minded forger was that, on that very night, wrote down in my Diary, in my own handwriting, all the incidents of the evening. It will be a big book, and I fear a dull book, that of $\mathrm{N}-$ 's and mine, but it can have one thing said of it that I believe no other contemporaneous work can claim, that there is not one word in it written from memory, and not one word from personal ill-will.

I hope it will be finished next spring-three volumes are already in type-and then I will try never again to think of it. I shall certainly never answer a criticism, or try to correct the vagrom memories of the Reminiscences. D-'s case was the only one I ever transgressed my rule in -and the result is a lesson.

After we left you, we made a ridiculously rapid run through Switzerland, went down the Rhine from Bingen to Cologne, then crossed to Brussels, and, after a day or two there, went back to England. M- M- said my throat was well, 
and we went to Scotland and thence to Wales, and came home on the $T$ - If you ever come home-if you do not resolve in "the hollow lotusland to live and lie reclined" the rest of your days, let me advise you to come home in that magnificent ship. It is the ultimate word of comfort and splendor at sea, and old $\mathrm{P}-$ is a jewel of a sea-dog.

I have as yet seen hardly anyone. I spent a few days with my mother in Illinois, and coming back shot ducks-shot at ducks, to be historicalin our marsh at S- for another week. Now I am here for a fortnight to knit up the ravelled sleeve of business-you know what tenants are. When I can get myself loose I go down to $\mathrm{W}$ - to plunge into that weltering sea of revision and proof-reading, whither, also, your intelligent sympathy can follow me.

HAY TO ADAMS.

Cleveland, O., October 22, 1889.

MY DEAR ADAMS:

I am grieved to think you are to fail, also, of your Mexico. My own disappointment did not 
move me half so much-for sufferance is my badge. I telegraphed $\mathrm{O}-$ yesterday to ask where $\mathrm{K}-$ is. He could only tell me to write care of the $\mathrm{E}-\mathrm{P}-$ National Bank.

Our Highland Lossie came home last night "late, late in the gloaming" like Kilmeny, escorted by two schoolboys, avid for the advertised reward. The children welcomed her without a word of doubt. The baby, at the first word of demur, shouted-_"Of course its Yossie!" and all the sceptics gave in their adhesion this morning, at the brilliant success of a test proposed by $\mathrm{D}$ He took her into the garden where she broke away and ran to a pile of leaves at the foot of the lot, and dug up a bone she had providently hidden there before her escapade. But I could not have believed a dog could have developed so rapidly in a fortnight. However, two weeks of vagrancy would accomplish a good deal in any young female. She has a detestable little air of having seen the world and being up to snuff.

. . . I I am trying to settle up my little affairs so as to leave here as near the 1st November as may be, and come to you. I have had two or three days of duck-shooting on our marsh;-no ducks, but a peculiarly fascinating landscape of wild rice and lily-pads. . . . . 
HAY TO ADAMS.

Cleveland, O., November 4, 1889.

MY CHERISHED LIVY :

I fully expected till an hour ago to bask in your "social wit" to-morrow. But things have concatenated themselves so as keep me here all this week.

So keep up a good heart! . . . . Give S$\mathrm{R}$ - my love and fond regrets! Give the Goddesses of the breakfast-table my worship and duty! Give the President three years' warning !...

HAY TO ROBERT LINCOLN.

Lafayette Square, Washington, D. C., Nov. 30, 1889. MY DEAR B-—:

We were very anxious all day yesterday-the morning papers having announced the dangerous illness of your boy in Versailles-yet we hoped for better news to-day; and this morning he still lives and there is further hope. We trust and pray the improvement may continue and that his youth and 
strength may soon restore him to perfect health again. Any other result would be too dreadful to contemplate.

Our thoughts and best wishes will be constantly with you, until we hear your boy is well again. Yours affectionately.

HAY TO ROBERT LINCOLN.

$$
\begin{gathered}
\text { Lafayette Square, } \\
\text { Washington, D. C., Dec. 22, } 1889 .
\end{gathered}
$$

MY DEAR R- :

It has occurred to me that you might like to get to the end of the Magazine publication of our book, without waiting a month, so I send you this last instalment. They are putting the book into type as fast as we can revise and read the proof, but it is an enormous job, and will require several months to complete it. Think of reading, carefully and critically (stopping every five minutes to make sure of a fact or a situation), five thousand pages, four times over! This we have to do, after the book is finished.

The publishers think best to have the whole book ready before they begin to publish-they 
will then put out the volumes rather rapidly, two at a time. There will be ten volumes. It will be dedicated to you.

I congratulate you most cordially in the recovery of your boy. We were very anxious till we heard the good news.

My kindest regards to Mrs. L- in which Mrs. H- would join me if she were here. She is detained in C- by the illness of her mother.

Wishing you a happy Year and many of them I am

Faithfully yours.

HAY TO HOWELLS.

Lafayette Square, Washington, January 22, 1890.

MY DEAR HOWELIS :

Where do you abide? I have a little framed picture by Masaccio which L. G. M- has sent me for your little $\mathrm{P} \longrightarrow$, and I know not where to direct it.

.... And how are you? I have worked so like a dray-horse of late that I have seen nothing, heard 
nothing, read nothing; our proof-reading is half over. You know nothing about proof-reading, with you it is the perusal of a charming author,-no more;-with us it is reading an old story, musty and dry, and jumping up every instant to consult volumes still mustier, to see if we have volume and page right in the morning,-and the dull story right in the text. I am aweary of it. . . .

HAY TO HOWELLS.

$$
\begin{gathered}
\text { Lafayette Square, } \\
\text { Washington, D. C., Jan. 23, } 1890 .
\end{gathered}
$$

MY DEAR HOWELLS :

I have just read your study on Lincoln, and will not wait a moment even to see Nicolay, before thanking you. I should be less than human if I were not pleased with such generous praise from such an authority; but I am delighted more than I can tell you in view of the fact that you selected for approval precisely those features of the work in which, in our opinion, its success or failure is involved. I felt that we had not altogether wasted our time when I read what you say about our sacrifice to our task, about Lincoln's treatment 
of $\mathrm{McC}-$ and his Cabinet, about $\mathrm{B}-$ and $\mathrm{J}-$ and $\mathrm{D} \longrightarrow$ - I like also what you say about Lincoln's use of words, and wish I had said it myself.

The work, big as it is, is really a tour de force of compression. In nine cases out of ten the people who criticize it blame us for having treated too briefly this, that, or the other subject, in which they are specially interested.

Thanking you again for the splendid and generous review, I am yours always.

HAY TO HOWELLS.

$$
\begin{aligned}
& \text { Washington, D. C. } \\
& \text { January 30, } 1890 .
\end{aligned}
$$

MY DEAR HOWELLS :

I sent M-'s money to the address you gave last night, and to-day I send you by express the little Masaccio, which shows a good deal of simple and touching beauty through all the outrage of time.

They will begin to put our first volumes to press before long, but I imagine it may be some months before any copies of the work come into our hands. 
Of course, one of the first has always been destined for you.

It warms my heart to hear you speak of $\mathrm{K}-$, though he gives us so little of himself. $\mathrm{He}$ is now in Cuba looking at mines for millionaires. $\mathrm{He}$ handles vast interests but cares so little for money that he gains very little. A touch of avarice would have made $\operatorname{him}$ a $\mathrm{V}$ - A touch of plodding industry would have made him anything he chose. Yet I fear he will die without anything except to be a great scientist and the sweetestnatured creature the Lord ever made,-but, come to think of it, that's something.

\section{HAY TO GILDER.}

$$
\begin{gathered}
\text { Lafayette Square, } \\
\text { Washington, D. C., Feb. 9, } 1890 .
\end{gathered}
$$

DEAR GILDER:

Last night I met Miss M- L- at dinner. She was very nice, and intimated to me that I had better never have been born. 


\author{
HAY TO BUEL. \\ Lafayette Square, \\ Washington, D. C., March 18, 1890.
}

DEAR BUEL :

We have been going on gaily for a week, and I hope we can keep it up. I shall charge my bill for quinine to you, if you keep me here till the malaria season. None but cats and congressmen can stand our August sunshine.

\title{
HAY TO HOWELLS.
}

\section{Lafayette Square, Washington, D. C., March 20, 1890.}

MY DEAR HOWELLS :

I have just finished reading "A Hazard of New Fortunes." I have read it not only with the pleasure I have in reading everything you write, but with constantly increasing admiration for the clear, artistic vision and the workmanlike grasp of your material which you are showing in these later years. I cannot always agree with you in your criticisms. You prize the one thing needful 
sometimes as if it were the only thing needful,but your own work is so infinitely better and finer, so much firmer in texture and so much more brilliant in color, than that which you so generously prize, that there can be no disputing with you while your ideas of art lead to such splendid results.

I think a little better of myself that I do not envy the persistent power and style of fellows like you and $\mathrm{A}$ - who are no younger than me, who have lost it all. I can write no more, I sincerely believe. After the next six months of proofreading, I shall feel that my work is done. But this is impertinence-I only wanted to thank you for a great pleasure.

HAY TO ROBERT LINCOLN.

Lafayette Square,

Washington, D. C., April 21, 1890.

MY DEAR B- :

Yours of the 8th arrived to-day. Mrs. H and $I$ have been thinking and talking of you and your sorrow for the last month. I am glad to hear that neither you nor Mrs. L- have 
broken down under it. You can never outlive it, but we hope that time may bring you peace, and that memory, which is now nothing but pain, may even become a blessing.

The artist who painted our children was J. $\mathrm{H}$ $\mathrm{W}$ - He has been very successful in several instances, in painting portraits of those he has never seen, from photographs. You will find him most amiable and reasonable in listening to all your suggestions.

$\mathrm{B}$ - has got his $\mathrm{P}$ A-'s out of town with great dexterity; the first act at least of the play is extremely successful. He has had so far an amazing run of luck, if you can call that luck which is brains skilfully used.

We have had serious reverses in the elections, so far as I can see without cause. I do not see how matters could have been better managed than $\mathrm{H}$-'s administration has done. We have finished our seventh volume. The book will be manufactured this summer.

Yours sincerely. 
HAY TO GILDER.

Washington, D. C., June 3, 1890.

MY DEAR GILDER :

Here is a sonnet which I hope may find favor in the eyes of you-past-master of the sonnet. If you think it worth printing, it is yours, without money or price-on the condition it be printed anonymously. I am rather too old a bird to be singing in this strain.

If you conclude to print it, tell me about when, and send me a proof.

\author{
HAY TO GILDER. \\ 800 Sixteenth Street, \\ Lafayette Square, June 5, 1890.
}

DEAR GILDER :

Your ear is all right-not so long, perhaps, is some editors. Pronounce "heaven" in one syllable, and there you are. If you prefer "sky," why "sky" be it. I have a preference for heaven, being a Presbyterian. 


\section{HAY TO HOWELLS.}

Washington, June 8, 1890.

MY DEAR HOWELLS :

I have had the impudence to collect all my verses, new and stale, into one volume which $\mathrm{H} \longrightarrow \& \mathrm{M}-$ have printed. But $\mathrm{I}$ have at the same time printed a little edition of them for my friends and lovers, of which I send you a copy. You will not suspect me of taking them too seriously in thus dressing them up. On the contrary, it is only the conscious amateur who does such things.

\section{June 11, 1890.}

... I have not, I think, told you how I was "seized" by your "Shadow of a Dream." You produce masterpieces faster than I can write letters. This is tremendous in power and grasp. Turgenieff himself might have signed those delightful and masterly pages. I am proud to feel such things are done in my time and by a friend of mine. 
HAY TO GILDER.

Washington, June 19, 1890.

MY DEAR GILDER :

I have at last yielded to your furious importunity and have written an article on "Life at the White House in Lincoln's Time." When will you want it? $\mathrm{N}$ - thinks he will write one or two, but cannot promise them immediately.

$I$ reserve the privilege of using the article as I please in future, and expect, of course, a monstrous honorarium for it-enough to put the Magazine into the hands of a receiver.

HAY TO ADAMS.

Cleveland, O., July 12, 1890.

MY DEAR ADAMS :

My dear neighbor, whom I love as myself, I was made quite gay by your letter for a minute or two, and it also gave a good minute or two to my missus. W- seems a far country and news from there are worthwhile in $\mathrm{C}$ - 
We leave here next Wednesday and take two leisurely days for our journey to $\mathrm{N}$ - I try to shut my eyes to what may happen when we get there. I shall be in the position of a school teacher without lessons and without authority. If I were only with you cleaving the blue waters of the Pacific, eating an occasional missionary with the unconverted natives, or, in default of that, carving a loaf of breadfruit " by the long wash of Australasian seas," I might recover the lost tone of my spirits. As it is, I enjoy little but sleep. I get plenty of that in this cool and breezy village. My day in New York was the hottest I remember, - the next day, here, I needed an overcoat, driving home from the station.

As Hafiz sang- "How sad were the sunset, were we not sure of the morrow!" and that is just our fix. That pleasant gang which made all the joy of life in easy, irresponsible W-, will fall to pieces in your absence. You were the only principle of cohesion in it. All its elements will seek other combinations except me, and I will be left at the ghost-haunted corner of 16 th and $\mathrm{H}$.

.... I had a letter just now from $\mathrm{H}-$ $\mathrm{J}$ - He had dutifully done his Ober Ammer- 
gau, which bored him, and he was going to leave Venice before Mrs. J_ arrived.

. . . . Give our loves to Mrs. C-. I wish I were looking forward to julep on her balcony to-night.

HAY TO ADAMS.

Boston, July 17, 1890.

MY DEAR ADAMS :

Your good letter reached me yesterday at $\mathrm{C}$ - when I was on my way to the station. It comforted me through the long journey, kidhaunted and hot, from $\mathrm{C}-$ to Boss-town. I have no excuse for writing to-night except that you said you had not my new address, which is, to wit: Newbury, New Hampshire. Thither I go at early fowl-crow to-morrow, to plunge into a barbarism profounder than any that Stanley came across in Jimjamjumbo. My desire to go to the Pacific with you increases at every new exhibition of the bellicose with my children; and yet I feel more and more that my duty lies here -to keep them from massacring each other. You are also a discoverer. You have dis- 
covered that my mare-is quiet. Let us give her a name worthy of her, and call her The Pacific. I got her as a life-insurance for the childrenand they unanimously refuse to ride her on the ground that she has no hustle on her. I do not know what my poor little wretches will do at Newbury;-they are looking forward to a season of summer opera-bouffe, instead of the deadly repose we have planned for them. I went out to-day and bought $\mathrm{D}$ - a carload of fishing tackle which he will never learn how to use. $\mathrm{He}$ did not even seem to care for the shopping. In my day, buying the hooks and lines, and digging the bait was fun enough, even if you caught no fish.

This is a wonderful city of yours in its summer sleep. Commonwealth Avenue and Beacon Street are as still as Tadmor in the desert-swathed in green cerements of Ampelopsis, as if earth's concerns were over for them. We should have felt quite lonesome had not our dear Gen'l Bturned up at lunch. His is the only familiar face we have come across in Boston. A few people seemed alive in a goodly building, which our hackman said was "a club of private gentlemen, called the All-gonquin." .... 
HAY TO ADAMS.

Newbury, N. H., Aug. 5, 1890.

MY DEAR ADAMS :

... Mrs. H- has once more proved her superiority to me in practical sagacity. This sojourn which I regarded with horror has turned out rather agreeable than otherwise. I do not mind the country fare. The children seem very happy. They have even more amusements than they can manage. They fish and row and swim. They colonize the desert islands in the lake. They climb the hills. They quarrel and fight and have a good time generally.

I cannot tell you how my heart sinks at the thought of your going away without me. I recognize it as the last ringing of the bell. I now feel that I shall never go west, and thence east. I shall never see California nor the Isles of the Sea. But we have resolved to begin building at once, and I must be here during the next three weeks. I am a worthless creature, destitute of initiative.

Yours, what there is of me. 


\section{HAY TO ADAMS.}

\section{Cleveland, O., Oct. 9, 1890.}

MY DEAR GLOBE-TROTTER :

I was made happy this morning by receipt of your letter begun in the Volcanic air of Kilauea and despatched from Honolulu on the 25th September. You are alive, which is a fact of more importance to us than to you, and I imagine you are having a reasonably good time-which, at our time of life is more than anyone has a right to expect. (I had a birthday yesterday and am consequently low in my mind.) You have attained at last the honors of the rose-garland, and the picture you draw of $\mathrm{L}-\mathrm{F}-$ in his, is worthy of being immortalized in glass.

I have nothing to tell you of affairs in this dusty world. Mrs. H- and I went to New York on the 23d to put $\mathrm{H}-$ to school at $\mathrm{D}-\mathrm{F}$ - It is a pretty place and she seems happy enough-but our house is dismal without her. ....

I . . . . start home to my mother on Monday next. Then I come back here and shoot at some ducks, and then go down to Washington. My visit to that capital is attended with some palpita- 
tion, as my Botticelli has arrived and is at my house, as yet unhonored and unhung. I am half afraid to see it, yet I wish to know the worst. But oh! the misery of the empty house next door!

My eyes are getting so rusty that I can read and write less and less, and what I am to do with my hours, what tongue can tell? I used to be sure of an hour or two of sweetness and light at your expense, but when will I enjoy it again?

Mrs. H- got a letter from Mrs. L yesterday saying Mrs. C- was leaving B-. She is expected in $\mathrm{C}-$, but of course she will not come. We went down to $\mathrm{B}$ - one day to see her. $\mathrm{C}-$ and $\mathrm{A}-$ had a delightful day with $\mathrm{M} \longrightarrow$. Mrs. L_— came over from $\mathrm{N}-$, and we talked, mostly about you, till train-time. We had no juleps, so there was little reminiscence of the Washington spirit.

The McK- Bill is now in full career. Your folks say the country is going to Sheol; my folks say it is saved from destruction. Stocks are falling,- - the conventions are resolving,- the orators are puffing. I heard $\mathrm{C}-$ and $\mathrm{T}-$ $\mathrm{R}$ _ speak in Faneuil Hall,-and you may not believe it, but $\mathrm{C}$ - made the more effective speech of the two..... 
What do you think? I relapsed from my good resolutions a while ago, and presided over a crowd of ten thousand people in New York to inaugurate a statue to Horace Greeley. I had built a monument to him myself-but l'un n'empêche pas l'autre. His daughter was there, on the whole the prettiest woman in America, (outside of your breakfast table), and she smiled at me so good-naturedly that I am more than ever convinced no human being has read a word of $\mathrm{my}$ calumnies.

Speaking of calumnies, your V and VI are out, and they lie on my desk; they are the first thing I shall read when I get the bandage off my eyes. (This letter don't count-because there's no one watching me.) There have been three columns of eulogy of it in the $T$ - Somebody in the $T-$ however is contrary-minded. He has written an article a mile long, vindicating $\mathrm{P}$ - and consigning you to "the dust-bin of oblivion." He signs himself Housatonic. But all these things, are they not written in the correspondence of $\mathrm{D}$ and have you not told me to hold my maul about such matters?

You have doubtless seen the fuss we are making over H. R. H., the Comte de P-. 
The 400 have not yet got in their work. He has been in charge thus far of $\mathrm{S}-$ and $\mathrm{B}-$ and $\mathrm{N}-$ of the Loyal Legion. S

received him at Washington in the absence of the Autocrat of the breakfast table, who is shirking his duty in the South Seas.

Miss L- is carrying all before her in London. She is reported engaged to Sir C$\mathrm{H}-$, and also to $\mathrm{G}-\mathrm{C}-$, eldest son of Lord S-. I hope she will bounce one of them-because she can't bring them both to breakfast - as even the Mormon Church has given up polygamy.

I wish I were with you. Your letter renews the infandum dolorem. I know now that I shall never see the tranquil waters of the Peaceful Sea. There was every reason why I should go with you, and none why I should not. So there is no hope left for me-though $\mathrm{K}$ - tries to comfort me by telling me he will take me some day. But he will never be ready. He still struggles against adversity. B- is dead and $\mathrm{S}-$ is in liquidation. But he thinks, or says, that things are going his way yet.

Give my love to $\mathrm{L} \longrightarrow \mathrm{F} \longrightarrow$ __ and keep yourself in good cheer, and don't stay away forever. 
HAY TO ADAMS.

800 Sixteenth Street, Lafayette Square, Dec. 12, 1890.

MY DEAR HENRY :

If it is any pleasure for you to know that you have planted the thorn of envy in the breast of a friend, you have the right to enjoy that pleasure to the fullest extent. I read and re-read your Samoan letter. I hang over your photographs and contemplate your old-gold girls, and interrogate the universe, asking if there was ever such a fool as I-who shall never, $\grave{a}$ grand jamais, enter that Paradise! K- says we will go some day, but $\mathrm{K}$ - will never be ready, nor will $\mathrm{I}$.

Everything has gone to tarnation smash since you went away. First the G. O. P. went to wreck over McK_—'s Bill, and the G. O. M. over Mrs. O'Shea's beak. Your own Democracy with its 150 majority is far from happy, as it is mounted on the Farmer's Alliance, and no man knoweth whither it goeth. $\mathrm{W}-\mathrm{H}-, e . g$., was beaten for the Senate yesterday by one Iwhose hair drops hayseed as he walks. The Republicans gang like ghaists but there are still 
lots of chances. $\mathrm{C}-\mathrm{L}-$ is a spared monument of the cyclone. . . . .

But politics are a bagatelle in comparison with the tornado of falling stocks. We are all poorer by an average of ten millions apiece since you went away and left the continent to its fate. I think I told you that three men had died, each one of whom ruined $\mathrm{K}$ - by his untimely demise. One would think that was his share of lethal casualties, but since that, two more have died, one of them smashed by a railway train at $\mathrm{W} \longrightarrow$, and each in his agony kicked over a full pail of milk which $\mathrm{K}$ — had been a year in drawing. Worst of all, that coal arrangement which he had cooked up with your brother $\mathrm{C}-$ - and which he looked forward to as a provision for his declining years, has gone to Hades with the revolution in $\mathrm{U}-$ $\mathrm{P}$ _. In spite of all he seems full of pluck still, is working like a Turk at new enterprises, and reads about viscosity the greater part of his night.

Things in W- are hardly worth writing. about. Old $\mathrm{B}$ - of $\mathrm{T}$ - made a speech about $J$ _ in the Senate last summer which scared the Commissioners into a fit, so that they have again changed the site of the Lafayette Statue to the 
southeast corner of the Square. They are digging a new hole for the foundation. Perhaps some other shining light of your party will object again, and they will cast the statue out to Oshkosh and make all the residents of the Square have a likeness of the hero of New Orleans branded on their behimesides. Your Triumphant Democracy is a bore.

Your modest soul has never yet conceived the vacancy you make in this little town. Your breakfast table is as a flock without a shepherd. They are scattered abroad and seem to possess no principle of cohesion. I have had the $\mathrm{R}-\mathrm{S}$ and $\mathrm{L}-\mathrm{S}$ to dinner once or twice, but $\mathrm{I}$ cannot make them gay. We try to put a little life into ourselves by abusing the mugwumps, but all our gaiety rings false, and we drop the effort and our voices, and talk of Samoa. By the way $\mathrm{H}-$ is losing his mind. I met him in New York and he told me to tell you he wanted Samoa history. Mrs. H- also spoke of her delight in your work, and while I am on the subject permit me to say also that V and VI took the cake. There is a gathering strength and interest in these later volumes that is nothing short of exciting. The style is perfect, if perfect is a proper word applied 
to anything so vivid, so flexible and so powerful. I never expected to read anything which would give me so much pleasure.

Mrs. C_ and Mrs. L_ are getting up a series of parlor concerts (Adamowski) in honor of you. The first one is to-day at the $\mathrm{R}$ - Legation. We are to have the next, I believe. Only fifty tickets are sold. Ces dames are desolate without you. They seek each other, but avoid the rest of the world. They read your letters and discourse of you-but they think your old gold girls are horrid. I have incurred their grave displeasure because I admire Fanua and Fangali.

$\mathrm{M}-\mathrm{V} \longrightarrow$ has come back from her conquest of the British Isles, prettier and more posed than ever. She bowled over the aristocracy without half trying. .... S S- has come and gone; and his wife, mother-in-law, and $\mathrm{H}-\mathrm{A}-$ still linger on at the $\mathrm{B}-$ Legation.

$\mathrm{S}$ behaved himself very well here-threw over a dinner at the Legation where thirty people were asked to meet him, and came to dine with me,telling Sir J- he would come to him the next day. I knew nothing of this until it was over. The $\mathrm{P} \longrightarrow$ - s were good-natured and did not seem to bear malice. The ladies are making a pet of 
A- - - he is certainly the youngest scxagen:rian I ever saw. He goes about in his pleasant, maidenly way, damning everything he sees. He even criticised the hands in C-_'s picture by Sargent. He thinks $\mathrm{R}$ - the best we've got, but devilish poor after all. Yet he is good company and agreeable for all that.

My big Botticelli has come and is hanging on the stairs. It is a beautiful thing-a picture of the first importance. I lie awake nights fearing it will warp, and get up in the morning to see if the convexity has become critical during the night. $\mathrm{D}$ — $\mathrm{T}$ - says it is a shame to bring such pictures to America, and I agree with her. I wanted $\mathrm{O}$ - to come down and look at it,-but $\mathrm{O}$ _ just to spite me, up and died. So far as I can learn, there is nobody in the country can stop a picture from going to the devil if it wants tosame as a boy.

Your desolate house is unfeelingly flourishing. $\mathrm{D}$ - was here for a few days but has flitted north again. B- is the guardian angel of the children. D— comes to the house occasionally, drunk as a lord, and swears he is ready to die for me. L- meets me on the street and asks when you are expected home. Ay de mi! W- 
McL- was buried yesterday. The next time you write, ask me some questions. I want to write to you, but I have nothing to say except that I miss you every day more and more and cannot get accustomed to the lack of you. Give my love to $\mathrm{L} \_\mathrm{F}-\mathrm{He}$ at least will come back one day and tell us many things.

HAY TO ADAMS.

Washington, Dec. 30, 1890.

MY DEAR HENRY :

... What a fool I was not to go-and now I shall never have the chance! The gates of Paradise are shut. I am too old and too inert to make the break. You are the only young man I know, and $\mathrm{L}-\mathrm{F}-$ is the only man of practical common sense.

There is $\mathrm{K}$ - for instance! He is in deadly need of just such a journey. He is down in the doldrums for good. His sister will be married next Wednesday, January 7, and instead of taking a ship and joining you, he says he must give up the rest of the winter to his mother, who is not very 
well. Every struggle he makes in his world of finance gets him deeper in the mire, costs him something of life as well as of money. It would be an advantage to his pocket as well as his immortal soul to drop everything and go sailing away to you and happiness. I think I would have the inertia to go with him, if he and my wife gave me a good shove. But he will not go.

Of course you will not keep your tryst with me in London this Spring. I would not if I were you. I do not know whether I shall go or not. I have taken my passage in the $M$ - of April 22, but I can always skip it. Mrs. $\mathrm{H}-$ rather thinks I will go-she will not. She cannot live with or without the children. I shall continue to intend to go until the 1st of April, and shall then make a seasonable fool of myself which ever way I decide.

You would come back out of mere pity if you knew how you are missed. We meet and talk of you in saddened whispers. Especially are you lacking when we have our little Adamowski concerts. The first was at S-'s, the next is to be chez nous, the third probably at B-'s. . . . . If we took any interest in the higher pleasures, there would be a plenty. The Geological, Histor- 
ical, Economical and Forestry Societies are to meet here within a day or two of each other. Everytime I pass your melancholy door I see men of learned and hungry aspect ringing your bell. . . . I have no news for you. My party is like a duck hit in the head since its defeat in the Fall. Your party, ridden by the Farmer's Alliance, and bound by dirty trade with the Republican silver men, does not know what to do with its vast majority. Both sides seem inclined to fool away the time till the 4th of March. H- has disappointed his enemies by making an excellent Supreme Court Judge in M-'s place, a man named B- of Michigan, quite a civilized being. But Wis as dry as a remainder biscuit.

... Really, I think you should come back and reconstruct your breakfast table. Your flock are in danger. They still mourn for you. But they will console themselves with dips and $400^{\text {s, }}$ unless you come back. And then what is to become of me, whose joy has been my daily attendance at the Oeil-de-Boeuf to catch a glimpse of the beauty and fashion that come to your court!

Mrs. L— and $\mathrm{C}-$ have fled from Washington in disgust and gone to $\mathrm{B}-$ for three 
weeks of the gaiety which is denied us here. The $\mathrm{P} \longrightarrow \mathrm{s}$ make a gallant struggle against the overpowering dulness by dinners and dances. ... . We cling desperately to the $\mathrm{L} \longrightarrow \mathrm{S}$ as our last hope, and even M- V- has little to say except to ask for the latest news of Polynesia. It is a dull world, my masters.

I have just read Daudet's " Port Tarascon." It is his definite Waterloo-everything is manqué. Now is your chance! Do a South Sea book, comme il n'y en a pas. It is a felt want.

I feel that I am shooting into the infinite azure in writing to you. If this letter ever gets to Tahiti you will not have arrived there or will have just gone. You are too remote. But I will go to the Post Office and put it in the slot with the same vague hope with which one subscribes to a Missionary Fund. Please tell me when you write again to address you care of The Queen, The Tower, London. There will be something familiar and definite about that.

Now I will have to tell you,-perhaps a dozen fellows have done so-of $\mathrm{S} \longrightarrow$ 's account of́ your visit to him. Your account of that historical meeting is a gem of description. I have it by heart. His is no less perfect and characteristic. 
He writes to $\mathrm{N}-\mathrm{B}-\mathrm{B}$ - "Two Americans called on me yesterday. One, an artist named $\mathrm{L}-\mathrm{f}-$, said he knew you. The name of the other I do not recall." Bear up under this, like a man, in the interest of science! It completes the portrait of your shabby parrot.

... Y You are losing nothing, I believe. I hear of nothing that is written-nothing that is said-nothing that is done. Nothing-“ "yet all there is, I hear." Even $\mathrm{S}$ - sends nothing for the moment to the $T$ - - -lying low with typhoid fever, but, his daughter writes me, convalescent.

HAY TO ADAMS.

Washington, Jan. 10, 1891.

MY DEAR FENRY :

I have nothing to tell you to-day except that there is the finest sunshine you ever saw in $\mathrm{W}-$, and that, on days like this, I feel the lack of an einwolner next door with peculiar keenness. I am trying to get accustomed to your absence, but it will not go. Your ladies can always drown their sorrow in the flowing flirtation, but nobody 
will flirt with me, being old and ugly. I am afraid you are having too good a time $l a-b a s$, and that we shall see you nevermore.

Mrs. H- now thinks seriously that I will go to London this spring. You, of course, will break your tryst, and what will poor Robin do then, poor thing? Stranded in London without a wife, family or friend to my back, and only $\mathrm{H}-$ $\mathrm{J}$ - to come to dinner with me!

You have learned, I suppose, through your countless correspondents that you have been elected to the place of Vice-President of the Historical Society ... and Don C- is unaniously renominated for the Senate, in which the Pennsylvania politicians build far better than they know in keeping intact the cultus of Lafayette Square.

\section{January 20, 1891.}

I wrote the foregoing sheet and lost it. To-day I find it on my desk. It is not worth the sending, but I send it along. It will say at least that we love and miss you. Of course you will never get it-you have become fabulous and inaccessible since you left Samoa.

.... The Adamowski concert at our house was 
delicious. The dining-room was filled - not crowded; and the quartette played as if blown open by Pan. All your friends and lovers were there, and it was as if a service in your honor were being performed.

We had a queer function last night at Lincoln Hall-a performance of a burlesque of "Africaine" by local home talent and two prime donne from Philadelphia and New York. It was very well done, and the house was the most brilliant I have ever seen in Washington. Miss $\mathrm{L}-$, in the most conspicuous seat in the house flirted coram populo with $\mathrm{S}-\mathrm{R}-$ all the evening. $\mathrm{He}$ is the mode this winter-all your breakfastresses say they are in love with him.

I have a letter from $\mathrm{K}-$. He thinks his mother's heart will break along of $\mathrm{M}$ —-'s marriage, and so he says he is to spend six weeks in $\mathrm{N}-$, and do what I have been kicking him to do for two years-write a sort of caveat on his viscosity racket. I have been expecting every day that somebody else would cut him off. . . . . 


$$
\begin{aligned}
& \text { HAY TO GILDER. } \\
& \quad 800 \text { Sixteenth Street, } \\
& \text { Washington, January 26, } 1891 .
\end{aligned}
$$

DEAR MR. GILDER :

Lincoln's Gettysburg speech cannot be considered in any sense "an extemporaneous effort." It was not only carefully considered, but was reduced to writing before it was delivered,--and very little changed in the subsequent copy.

\author{
HAY TO ADAMS.
}

Washington, March 25, 1891.

MY DEAR HENRY :

I received your good letter of the 8th of February last night, and began to appreciate the dreadful distance which separates us when I read that you could not expect an answer before the middle of June. I have lost heart in writing to you, as I know you get all public news in the $T$ - and all private intelligence from your many friends and lovers here. $\mathrm{C}-\mathrm{L}-$ tells me he has written you all about the works of the late 
Congress, and so estops me from intoning a hymn to you on the passage of the Copyright Bill and the French Spoliations restitutions. These two events I fear will make you too rich to go to Heaven, and as I am apparently never to meet you again on earth, the prospect, as your cousin $\mathrm{S}-$ said :-_ Brings me blue. . . . ."

I do not know where to begin on our small-beer chronicles. In the first place, everybody is dead. $\mathrm{S}$ — and $\mathrm{P}$ - went out together, hustling each other on the golden stairs; and yesterday we buried old J-J—at St. John's. A few dozen shabby Southrons, in faded butternut clothes, came up from Virginia. Dr. D__ rattled off the prayers of usage, and then the old hero was literally carted off to B- and dumped into the ground with ceremony so scant as to arouse the fierce wrath of the Maryland secessionists. Only $\mathrm{B}$ - is now left of the greater rebels-for they think little of L_-, the best of the lot, because he has behaved himself since the war ended, and behaving oneself is a thing the southern heart revolts against.

....Y You were kind enough to make some inquiry about the big book of $\mathrm{N}$. and $\mathrm{H}$. It is out, and out of my thoughts. The agents are 
selling a few copies, I believe, but have heard nothing about it. Next winter, the publishers will tell us. The newspaper notices have been friendly but cursory. In cases where they have printed two or three columns, they have given three-fourths of the article to the first volume, and then finding that at that rate they would never have done, they have slung in a few compliments and stopped. J- W- $\mathrm{W}-$ is writing a very elaborate paper on Lincoln as a military commander-the first instalment covers nearly a page of the $S-$ He is very civil to us.

.... To-day D- and I went to Rock Creek where we were joined by Mrs. C- and Mrs. L_- Mrs. H_— could not go, being laid up by a severe cold. Mrs. C- and $\mathrm{D}-$ will send you the fruit of their cameras. The work is indescribably noble and imposing. It is, to $\mathrm{my}$ mind, St. Gaudens's ${ }^{1}$ masterpiece. It is full of poetry and suggestion. Infinite wisdom; a past without beginning and a future without end; a repose, after limitless experience; a peace, to which nothing matters-all embodied in this austere and beautiful face and form. ....

${ }^{1}$ The monument to Mrs. Adams, by St. Gaudens. 


\section{HAY TO ROBERT LINCOLN.}

\section{Duke St., St. James.}

$$
\text { May 2, } 1891 .
$$

DEAR B- :

It has just occurred to me that some of my fellow passengers may have mentioned the fact of my arrival. This, therefore, is to prevent you from engaging Stanley to organize a search party through Darkest London for me. I am enjoying a little grippe so as to be in the fashion and shall not be out for a day or two. When I emerge, my first errand will be to pay you my humble duty.

\section{Yours faithfully.}

HAY TO MRS. WHITELAW REID.

$$
\text { London, May 28, } 1891 .
$$

MY DEAR MRS. REID :

I think I will never be conscientious again. I had a pleasant journey over, but yesterday morning just after breakfast, I had the worst half hour I have ever had,--turned the house upside down, frightened the Doctor, and sent for $\mathrm{S}$ - to have 
my remains sent home,- - the consequence of all which was that I could not go to Sir C$\mathrm{H}-$-'s dinner, of which I was the occasion, and am shut up for I don't know how long. I am profoundly disgusted.

But that does not prevent me from being also profoundly grateful to you and Mr. R- for the delightful visit I had in Paris. I grew better every day I was with you, and I believe it was the London air that broke me to pieces on my arrival. . . I I am not sure I shall wait until July before sailing. My temporary doctor advises me to go home as soon as possible, but I think I will wait until $\mathrm{M}-$, - who has the influenza-is well enough to see patients before I decide. . . . .

I am glad I am not a great man. How the $H$ would go for me!

\section{HAY TO ADAMS.}

$$
\text { London, June 4, } 1891 .
$$

MY DEAR HENRY :

I received two delightful letters from you while I was in Paris last week ; one was dated the $3 \mathrm{~d}$ of April, that came first; and a few days later came 
another dated March 3d. They were devoured with the greedy interest with which everything from you is received; but the best thing about them was the indication they conveyed of a dawning purpose of coming back to the world. Mrs. $\mathrm{C}$ - was in Paris, and I sought her genial presence and we took sweet counsel together concerning you, and encouraged each other a good deal in the hope of seeing you again before we die in Lafayette Square.

She arrived in London last night, and I have just come from B-'s Hotel, where she is staying. I saw M-, too. She seems to me a rather humorous, middle-aged woman, who, before speaking, asks herself how she shall best convey the impression that she is a sweet, serious and charming child of five. Ces dames do not like Paris. They were bored to death by their dressmakers, and felt genées and hampered by the verfluchte Franzosenheit of everything. There was a great function at $\mathrm{R} \longrightarrow$ 's the other night. . . . It was an immense ball, 1500, and it seemed like the resurrection of the unjust. All the old idlers I had known in Paris nearly thirty years ago were there still, a little grayer, but no less idle. ... $\mathrm{R}-$ is doing the thing with conscientious 
splendor, and his wife with laudable energy, but but they do not like it.

I spent two days at the two Salons. I rather thought the seceders at the Champs de Mars had the best of it. The pictures that attracted attention were not great works of art, but the anecdotes, the epigrams. There was a "Dinner at the Pharisee's" by B__ the traditional Christ seated at the head of the table; at his feet grovels a pretty Parisian cocotte; all around men of to-day, in Poole coats, stare and wonder or leer. ...

Miss M- L_— and her mother-the inversion was involuntary-came over with me from Paris. She is embarked on the full tide of London dissipation; the days are not long enough ; the nights are too few, for her gayeties. I had a little dinner at the $\mathrm{B}$ - when I first came over, which was almost like your breakfast-table. It was in honor of Mrs. C- and her callow brood; the $\mathrm{L} \longrightarrow \mathrm{s}, \mathrm{D} . \mathrm{O} . \mathrm{M} \longrightarrow, \mathrm{Mrs} . \mathrm{R}-, \mathrm{B}$ $\mathrm{H} \longrightarrow, \mathrm{H}-\mathrm{J} \longrightarrow$, y pico. But I suppose Mrs. C- has told you about it. It was as pretty a lot of women as were seen anywhere in London that night. . . .

I have been in wretched health since arriving 
here-had influenza, followed by every other fiendish complication you can imagine, ending in fainting fits, which the great diagnostician Bsays is nerves and not heart-as if that made it any more amusing. I would not have mentioned so dull a subject except to account for the fact that I have no news to tell you. I do not go to Court, nor anywhere among the mashers. I told you, also, to let you know that if you want to see me alive, you had better get a hustle on you and come home. ...

I have seen most of your intimatest. The $\mathrm{C}-\mathrm{s}$ are here for a few weeks. Robin took me into B_'s and gave me a cup of tea, which I understand makes me respectable forever. I dined the other night with $\mathrm{T}$ - and another night with $\mathrm{M}-\mathrm{G}-\ldots \mathrm{B}-$ _ me to dine to-morrow, and I sadly fear he will talk copyright, of which I know not a traitor word. ....

I got a letter from K- yesterday. He had received your geological treatise, but was waiting for $\mathrm{B}$ - to determine the value of $y$ before answering it. $\mathrm{He}$ is far from well, poor fellow. He had taken advantage of my absence to make my wife a little visit. She had taken him out to 
Rock Creek and shown him your monument. He thinks, as I do, that it is the most important work yet done on our side; - the best of St. Gaudens or anybody else.

. . . I I dined with $\mathrm{L}-$ last night. He has a very good house, Lord D-'s (who claims to be the elder branch of Hapsburgs and has black eagles all over the place), and lives very well. $\mathrm{M}-\mathrm{V}-\mathrm{L} \longrightarrow$ was there, and very handsome .....

I sail for home on the first of July, and go at once to $\mathrm{C}-$ We hope to get to $\mathrm{N}$ - Wor August. I do not know whether I shall go to ' $\mathrm{T}$ - or not. I am not well enough for a long journey-though I knock about London as if nothing was the matter.

I hope I shall live to see you again-somewhere.

\section{HAY TO $\mathrm{C}-\mathrm{S}-\mathrm{H} \longrightarrow$. \\ London, June 18, 1891.}

I spent a delightful day at Cambridge yesterday. I arrived there rather early and after driving out to the $\mathrm{M}-\mathrm{s}$, which is a mile or 
two out of town, I found they had come in to a lecture at the University. So I left my box and came in and spent an hour or so loafing about the beautiful colleges and lawns and the banks of the Cam, where hundreds of boats were plying, full of boys and their sisters and friends. The scene was beautiful-the quiet river, the green banks covered with a gay crowd and hundreds of red parasols. Sometimes a boat would capsize and the crowd would roar with delight. The old buildings are very fine and venerable; the day was perfect.

At lunch time I went back to the $\mathrm{M}$ - 's place and found Mrs. M-s and Mrs. T-, $\mathrm{M}-\mathrm{S}$ and Sir A- L- and one or two others. I like $\mathrm{M}-\mathrm{s}$ very much indeed. His manner is precisely like Mr. M-, only, of course, he is a great scholar and poet beside. The ladies were very amiable and sent their love to you. After lunch $\mathrm{M}-\mathrm{s}$ took me to walk over the place, which is very pretty. $\mathrm{H}-\mathrm{A}-$ was there, but left for London in the afternoon. His American drawings are wonderfully good, especially the California ones.

The procession of the boats took place at 6 in the afternoon. The $\mathrm{M} \longrightarrow \mathrm{s}$ had tickets for the 
Bridge, which gave us a splendid view. The boats (8 oars), 26 in number, were brilliantly decorated with flowers and it was a noble sight to see them rowing down the river in procession, cheered by the friends of each particular college on the banks. You know Cambridge University includes a large number of colleges.

We went back and had dinner at 8 . Besides those in the house there were two or three learned Cambridge men and women and $\mathrm{F}-\mathrm{L}$ of New York, who is a very pretty and bright girl. $\mathrm{H} \longrightarrow \mathrm{W} \longrightarrow$ 's half brother, $\mathrm{B}-$, was there; he takes his degree this week with great honor and is engaged to marry an English girl from Newnham, who is also at the head of her class-a very learned pair. $\mathrm{He}$ is coming back to practice law in $\mathrm{B}$ - -

After dinner $\mathrm{M}$ - - asked me a great many questions about America. He thinks English women make better wives than American, because they are more obedient and devoted-which I suppose is true, but we like our kind best, all the same.

I got up bright and early this morning, but had to wait a good while for my shoes. When I came down stairs, Mrs. M-- , who had been 
lying in wait for me-rushed at me and said: "Oh, Colonel John Hay [she always gives me the whole name], I want your photograph." So she dragged me to her studio in the garden and up the stairs and flew around arranging her camera and plates, like a whirlwind in petticoats; she was so eager she cared nothing for looks; she jumped down on her knees, went over the floor on them, pulling the machine hither and yon, talking volubly all the time and took four before she got through. I know I shall look like a worm, for I felt so. Somebody came and knocked at the door, which was locked. She shouted, "Tell Mr. $\mathrm{M}-\mathrm{S}$ what I am doing and not to wait breakfast." Breakfast was nearly over when we made our appearance.

I had intended to start for Scotland to-morrow, but I felt so uncertain I thought I would go and ask $\mathrm{M}$ - He looked me over carefully and said I must not think of it this week. So I must give it up entirely for I can't go next week. I have written to Sir J__ expressing my profound regret. I am very sorry, but I am in such a state of nerves that if I had a bad turn in the train or at $\mathrm{T}$ - it would be very awkward. Here I can take the proper remedies. 
M- prescribed a generous diet and a good deal of stimulant with iron three times a day. He says I will get over it after a while. Says I had better go about as if nothing was the matter, taking care not to get over fatigued.

I lunched with the $\mathrm{W}-\mathrm{S}$ to meet the $\mathrm{P}$ $\mathrm{P} \longrightarrow$ - Present Lord and Lady A-, Lady $\mathrm{R} \longrightarrow, \mathrm{K} \longrightarrow$, Mr. and Mrs. de B-, Danish Minister, Lady J_ and one or two others. I took down Lady A - and sat between her and Lady $\mathrm{R}$ —. It was very pleasant and broke up early, as lunches always do here.

Friday, June 19. Last night there was a grand dinner and reception at the Legation for the $\mathrm{P}$. $\mathrm{P} \longrightarrow$ - s. Present, at dinner, Lord and Lady ALord and Lady A-, Belgian and Swedish Ministers, Sir W. and Lady $\mathrm{P}-$, the $\mathrm{E}-\mathrm{s}$, $\mathrm{W} \longrightarrow$, Mrs. A- $\longrightarrow \mathrm{B}-\mathrm{M} \longrightarrow \mathrm{s}, \mathrm{C}-\mathrm{s}$, $\mathrm{B}-\mathrm{s}, \mathrm{S}-\mathrm{s}$, etc. I took down Mrs. Aon my left was Mrs. B- M-, who has asked me to dinner and Opera to-morrow night. After dinner, there was a rather large reception. The American colony in force and some nobility and gentry. The house opens up very finely and the whole entertainment was in excellent 
style. Mrs. $\mathrm{R}$ - was not to escape, after all. The $\mathrm{P} \longrightarrow \mathrm{P} \longrightarrow \mathrm{s}$ are going down there next week, so as to have a visit with Mrs. $\mathrm{R}-$, and then come back here and finish up! There's sense for you.

Mrs. Y — T - was there. She had had a little tea for Mrs. C_— yesterday and asked me why I didn't come. I said I was not asked, whereat she blushed rosy red. W- says L-_ was a great success at the Palace on Wednesday night. The Royalties were quite attentive and so everybody else was. She likes it so well she would like to stay a year, but is afraid she won't be let. $\mathrm{H}-\mathrm{B}-, \mathrm{I}$ think I told you, goes home with the $\mathrm{O}-\mathrm{M} \longrightarrow \mathrm{s}$ the 15th of July. The Prince was very polite to her and sent messages to her father.

The $\mathrm{A} \longrightarrow \mathrm{s}$ are coming over this fall and Lady $\mathrm{R}$ - is anxious to see $\mathrm{N}$ - in the season, but she cannot stay more than a month or so, and hardly knows whether to prefer Newport or New York and Washington. 
HAY TO ADAMS.

$$
\begin{gathered}
\text { Newbury, N. H. } \\
\text { Aug. 20, } 1891 .
\end{gathered}
$$

MY DEAR HENRY :

Your letter of the twentieth of June reaches me here to-day. It is a far cry to Fiji and two months is not much, after all. The news with which you conclude starts my pulses more than anything you have written yet. ....

I hardly remember what I wrote you last. At all events, nothing has happened since, worth talking about. I came here the end of Julyfound everything in confusion and a lot of workmen dawdling. I started things going, and, after a week or so, sent for Mrs. H- and the children. We get along well enough in the half-finished house, and amuse ourselves watching the painters and paper-hangers. The house, such as it is, will be finished by the time we leave it next month.

I wish I could take ship to-morrow and meet you in some of the effete capitals of Europe. But I must dree my wierd. I go to $\mathrm{C}-$ from here, and to $\mathrm{W}-$ in November. My winter will be spent in editing the Works of A- Lto whom I then bid an everlasting farewell. . . . . 
HAY TO ADAMS.

Winous Point, O., Oct. 24, 1891.

MY DEAR HENRY :

A letter to you has been weighing on my mind for a week or two, but yesterday your long and interesting letter of the 29th of September arrived, to put me still more hopelessly in your debt. It was a splendid wind-up of your circumnavigatory series. Ceylon, the mangosteen and the durian will always hereafter be objects of my hopeless passion. Of course I shall never know them. I envy you many things, but, most of all, that power of making up your mind to do things, and then doing them without any fuss.

. . . I I read your letter under unusual aspects. $I$ got it at noon as I was starting out in my boat. I went to a remote pond in the marsh, and as the water is unprecedentedly low, we had to push and pull the boat through mud two feet deep a half a mile. We got there at last, after unspeakable trials, built our blind, and waited for ducks, "the tardy ducks that didn't come." So under the level evening light that streamed across the wild marsh, turning the reeds and the cane to amber, with a wind cutting to the marrow of my bones, 
I read your letter, and contrasted your wise and fruitful method of amusing yourself with my melancholy attemps to be gay. I asked, with the immortal Flanagan,- "Why am I here?" and got no satisfactory answer.

We are a queer lot of odds and ends. You have met $\mathrm{B}-$ and perhaps $\mathrm{Col} . \mathrm{H}-$ - There is no one else noteworthy except B-, the electrician, the Cleveland Aladdin-a magnificent creature, 5 feet 2 in height, weighing two hundred and fifty pounds, who eats three ducks for his lunch, and then asks me about Carlsbad; thinks " he must go there"; is "getting heavy and bilious."

Then there are two or three old men from 80 to 90-original members of the Club,-in whom every passion, lust, avarice, appetite and thirst, are all gone, and nothing is left but the inextinguishable love of killing ducks. They get up at daybreak and shoot till it is so dark they cannot see their last ducks fall, and then limp in to supper groaning and whimpering, and nodding with sleep. 


\section{HAY TO ADAMS.}

\section{Washington, Dec. 17, 1891.}

MY DEAR HENRY :

It is a fine, blowy, blustery day, with occasional flurries of snow, but inexorable sunshine through it all. The children have gone to school, and Mrs. H— sits by my desk embroidering handkerchiefs. I ask her what to say to you (for of a truth I have nothing to say out of my own head). She says:- “Tell him to come home!" So this is the burden of my song.

I do not want to lie to you. We are too near Mount Vernon and the cherry tree for that. I cannot offer you many inducements. We are as dull as Chelsea. But we all think it is because you are away, and that, if you would come back, nods and becks and wreathed smiles would come back with you. But, if you are having a good time where you are,-if you are, as an old Dutchman used to say- "Gomfortable mit yourself" do not come back. You never saw us so dreary as we are. The dips who used to be amusing are gone or dead. S- still survives, though he has had the grippe-but he is going to Japan any minute. $\mathrm{M}-\mathrm{H}-$ is a melancholy anatomy, 
with little or no physiology left. . . . Mrs. H has only been here a day or two. I came a week in advance, and $\mathrm{S}$ - made me entertain two travelling English noblemen at dinner. We tried to be gay, and the women looked extremely pretty in their new gowns. Mrs. C-'s Parisian bravery causes all the others to die with envy, though she is bon prince, and has given Mrs. L- some of her gowns. She is an extraordinary woman, her dresses fit everybody. The two of them give me no peace, saying continually"Why don't you write to Mr. Adams to come home?" And as I told you before, I am not safe even at my own fireside from the same solicitations. But what can I do? I can say I hunger and thirst for the sight of you, but that is all. If you are happy where you are, I would be sorry to see you change your habitat. For I feel myself just now the worst company in the world and as if I should not cumber the earth much longer.

$\mathrm{K}$ - - was here for a day last week. He went to your house, intending to stay ten days and write out his caveat on "Viscosity." But the devil of ill-luck still pursued him. He struck a bad snag in his final experiments, and now has doubts of his thesis. ... . In fine, we are a bad lot, and 
getting no better. Perhaps we would all pluck up a spirit if you came back, but-quien sabe? I can only say you are ardently desired. Your vacant house casts a gloom over the sunny spaces of Lafayette Square. I went with $\mathrm{K}$ - to call on Mrs. L-. She flew at him and begged an invitation to breakfast. But even this resource turned to ashes in our hands.

HAY TO ADAMS.

800 Sixteenth Street, Lafayette Square, Jan. 6, 1892.

MY DEAR HENRY:

I have your letter posted from Paris on Christmas Day. I am sure I wrote you some sort of a letter last month which you ought to have received before Noël. But it makes little difference whether you got it or not. It contained nothing but one long wail over your absence. I have little more to add to-day.

Our family Christmas party begins to break up to-day. $\mathrm{D} \longrightarrow$ has gone back to $\mathrm{C} \longrightarrow . \mathrm{H}-$ has another week and then she and my wife go to New York. I shall be a bachelor for a week, and 
if you were here we would lark it-in a discreet and futile fashion suitable to our years.

I have this day a letter from $\mathrm{K} \longrightarrow$. He is in ill-condition every way ; I should say "Viscosity" has gone to the bowwows for the present. He has torn to pieces every known theory of upheaval, his own included, and is now squirming under the ruins of the temple he has demolished. He has got to go to work all over at the volumetric structure of the molecule considered specifically, and its behavior under physico-chemical stresses. This will require a trifle of two or three years before he can see any result. His business affairs are on ne peut pis. If he would stop struggling, he would get on well enough. He owes nobody but those who will never bother him. But he patarges in the mire as if his life depended on his getting out-and gets deeper in all the time. I have just written him a letter and talked to him like a Dutch uncle. Singularly enough, he is just as good company as ever if he were not so infernally busy that you never can get him to stay more than a half a day anywhere. I am in despair about him. I cannot make him do what he ought, even though I offer to stand the racket. Thanks for the L- article, and the "Prise 
de Possession." You ought to be happy in a town where such things are said and done. In this town there is thick dulness such as may be felt. I know I am running a risk in telling this to you while I am imploring you to come back. But I feel sure that the dulness will rise like a morning fog if you will come back. I and my family will be happy, and the $\mathrm{L}-\mathrm{s}$, and the $\mathrm{R}-\mathrm{s}$, and the $\mathrm{C}-\mathrm{s}-$ and it makes no difference to any enlightened mind whether other people are gay or not.

Your Brother B- came down last week and read a first rate paper on the suffrage before the Historical Society. He scared some of the D. D.'s by saying that the right and wrong were purely conventional definitions of certain incidents of evolution. Then he called on little Mrs.and told her that when a woman was bored at home, it was her duty to run away with another man. She bore up till —_ came from the and then fell into hysterics and his arms. Bonly staid a day and then hurried back to his wife - profoundly disgusted because $\mathrm{H}$ - had not declared war on $\mathrm{C} \longrightarrow$, so is $\mathrm{T}-\mathrm{R} \longrightarrow$. He goes about hissing through his clenched teeth that we are dishonest. For two nickels he would 
declare war himself-shut up the $\mathrm{C}-\mathrm{S}-$ Commission, and wage it sole. It is very amusing to see how your party wooled B- for his jingoism, and how they are now pounding him for his cowardice, since they find he is not inclined for war. We have been awfully near a fightbut it seems just now as if B- had got the strings in his hands, and that there would be nothing but diplomatic squabbling.

By common account it is to be a dull winter socially. Yet there is more dining and dancing than I have ever seen here. Last night the $\mathrm{B}-\mathrm{s}$ took the new Arlington rooms,-built since your time,-_and gave a big bal de début for L- All your little friends were there in their prettiest frocks. The débutante looked very well-as perfect a jeune fille Francaise as you could imagine. It was a great success. I came away before the cotillion, which Mrs. C- very beautiful in black satin, danced with $\mathrm{M}-$ $\mathrm{B}-\mathrm{C}-\mathrm{B}-$ and I sat with Mrs. Lon a sofa, and talked Civil Service. I think it was Civil Service-we complimented her eyes. She has recovered her grippe and is in fine force this winter. Mrs. C- is at her best, which is superlative enough. One never sees her, though, 
except through a fluttering haze of "dips" and dudes. Sacré nom d'un escargot! Why don't you come back and reintegrate your breakfast table. Do you not see we are all going to the Fiend without you?

HAY TO ADAMS.

800 Sixteenth Street, Lafayette Square, Jan. 25, 1892.

MY DEAR HENRY :

Your letter from London with its startling proposition arrived yesterday. Of course there can be but one answer. I had thought never to write another page for print-though I am making occasional raids on my wife's portfolio for sonnets and verses vain,-and really I am not at all sure that enough of my faculties hold together to produce a coherent chapter of copy for your book. But in face of the inducement you offer, I can only say :-Come home, and I will do my possible, if it takes a leg. So there you are, and you can pack your portmanteau when you will.

I imagine we have had all the foul weather a Washington winter can furnish, and when you 
get back we shall be beginning our Spring. If you should get here before the good weather comes, you can go with the $\mathrm{C} \longrightarrow \mathrm{s}$ and $\mathrm{L}-\mathrm{s}$ to $\mathrm{D}$-'s new pleasure-dome which he has decreed on St. H-C's island, South Carolina. I passed a winter there once, when I was a boy in blue and buttons, and it is a sweet island of soft sunshine and magnolias. I heard the two ladies arranging this échappé the other night, after we had dined luxuriously off a pig of $\mathrm{H}$ parentage. D- is growing sociable. He has dined with me and the $\mathrm{L}-\mathrm{s}$ and the $\mathrm{S}-\mathrm{s}$, and I don't know how many other places, recently, and he sits at his own table and carves the pig.

.... L- F-writes me from New York that grippe has had him in its clutch and that my window will be finished some day. God willing. $\mathrm{K}-$ has been desperately ill of the same malady, his life in danger for several days. $\mathrm{He}$ is now recovering, but the trouble with that sort of disorder is that you grow worse every day of your convalescence. To speak of something more cheery, Mrs. $\mathrm{H}-$ and $\mathrm{H}-$ went to the Yale gayeties last week-four balls and a dozen dinners and teas. It is the one spree that custom allows schoolgirls and $\mathrm{H}-$ drank 
deep of the cup of folly. She danced her dresses into tatters and her shoes off her feet, and when she got back to school her teacher winked at her and forebore to chide.

I haven't a news to my back.

\section{HAY TOे WHITELAW REID.}

Lafayette Square, April 20, 1892.

MY DEAR REID :

I have had sent you a copy of our "Abraham Lincoln." I cannot ask you to read it, for at our time of life, time is precious; but you will accept it with the love of an old friend, who, it is now reasonably sure, will never be anything else.

You have my sincere condolences in these trying days of banquets. I enjoy reading the speeches made at you, and still more those you fire back, which as a rule are better than you get. But I shall wait until you settle down into your everyday happy life, with your wife and children, before I can really congratulate you. My love to them in the meantime. 
HAY TO ADAMS.

$$
\begin{aligned}
& \text { Cleveland, O., } \\
& \text { June 16, } 1892 .
\end{aligned}
$$

MY DEAR HENRY :

I envy you sitting at your ease in your hotel, nursing a serviceable leg, and restoring your soul by a contemplation of Lafayette Square; while your poor friends and servants have been in Tophet. I think I never saw two days so hot as Monday and Tuesday. The car in which we went to Boston was $100^{\circ}$ bien sonnés. We gasped all night without sleep, and then went down to $\mathrm{N}$ - through blasts from hades. There was a blessed relief when we got there, for the breath of the sea was cool and fresh. Clooked pale and pretty; so did C-, M. C.; Mrs. L_ looked tragically unhappy though she braced up at the reception and seemed quite like herself. There were a lot of pretty people, though as usual Lafayette Square knocked them endwise. Mrs. C- looked as if a day or two at $\mathrm{B}$ - had brought back all her beauty. $\mathrm{R}$ - was radiant;-poor $\mathrm{H}$ - showed the suffering of $\mathrm{M}-$ -

We are plunged in a vortex of gayety. Mrs. 
$\mathrm{S}$ _ had a reception last night for the Faculty of the Woman's College. To-day we drive five miles into the country to another reception. Next week is full of baccalaureate business, and I must tell what $\mathrm{I}$ think about $\mathrm{H}-$ and $\mathrm{R}-$ to all our leading citizens. Only I don't !

Would I were with you in Lafayette Squareor on bounding billows-or by the pleasant Dee side!

HAY TO ADAMS.

Cleveland, O., June 21, 1892. MY DEAR HENRY :

The Corporation of Western Reserve University, with entire unanimity and ombliferous enthusiasm, made you to-day an LL. D.

It is no small shakes of a hayseed College, I would have you know. It has a Faculty of Arts, one of Medicine, one of Law, one of Music, and a Woman's College on the other side of the street. This whole blessed week is to be taken up with its functions, and next week I go to Illinois to visit my mother.

To-morrow or next day you will be so happy $16^{2}$ 
and gay over the nomination of your fellow-mugwump C- that there will be no enduring you. Well, go to! Be as happy as you please! You can never take away from me the blessed memory of four years of $\mathrm{H}-$ -

.... My heart is heavy for the $\mathrm{B}$ Why should one care for anything in this farcical world? That old lunatic of a T- is the only sane person living. "The first generation of sensible people on earth will be the last."

\section{HAY TO ADAMS.}

Newbury, N. H.

August 18, 1892.

MY DEAR ADAMS :

I have been waiting for a month for news from you, but to-day Mrs. H__ informed me that if I wanted a letter from you, the best way to get it was to ask for it. Wisdom drops from her lips. So please, write me one. That, I think, is all I have to say.

We live a languid, vegetable life. Everybody asks me:- "What do you do?" and the question leaves me speechless. We come here to escape 
doing anything. I shall never do anything again. It comes as near being amusing as I ean now attain.

I went to Boston the other day to take $\mathrm{H}$ to the $\mathrm{L}-\mathrm{s}$, who have kindly offered to care for her for a few days. ... Your sister A_ I found bright and gay, but was not allowed to see much of her, as C- walked me off to the cliffs and talked politics. He is not downhearted about his own prospects, and is quite cheerful about the national campaign. I do not prophesy and do not bother. Tammany can take care of $\mathrm{C}-$ _ ; and you-having nominated $\mathrm{H}-$ _ - can take care of him without my intervention. . . O Oh, my sweet Gods of Olympus, why did you make men of clay, when you might just as easily have made them of Standard Oil, or Yucatan Gum, or something nice.

... My flock is all perfectly well except D_-, who limps still. We shall have two doctors go over him next week to see if the limp is habit or hip joint. . . . 
HAY TO ADAMS.

Newbury, N. H.

Aug. 26, 1892.

MY OWN DEAR ADAMS:

Your letter of the 10th August reached me here yesterday. It was very good of you to write to me before receiving my letter-but no more than was natural. You are always good, and you write a beautiful hand, and have a lot to say; while I am a reprobate, and have scrivener's palsy, and am dumb.

We were very much interested in hearing of your establishment at G- Lodge. Fortune favors the brave. I should never have had the gall to take a house in England for the summer; but to you it seems simple as good morning.

\section{....Mrs. $\mathrm{H}-$ and $\mathrm{D}-$ and $\mathrm{H}$}

came back from a short visit to Boston yesterday in a fury of rain which seemed trying to drown out our mountains and wash away our lake. Two doctors sat on D-_ - a New York man, and $\mathrm{C}-\mathrm{W}-$. The net result of all the pow-wowing is that they don't know what is the matter with him :- that they don't think it is hipjoint, and that it probably is:- that he will 
probably get better of it, if he don't get worsethough he may remain as he is: - that the main thing is to consult frequently with an able doctor. "I," said W—, with a fine candor, "am as able as any."

So I shall give D- a week off, and send him to the marsh to shoot ducks. He will like it whether it hurts him or not.

... . I wish I could think of something to tell you. There is, I am told, a good deal of politics about, but I know nothing about it. . . . . Your letters to $\mathrm{B}$ - and $\mathrm{T}$ - were models of style and tact; nothing better could have been done; but $\mathrm{T}$ - goes pendering through the town, wondering if you really think education is on the whole worse than infanticide. I told him it was, but I doubted if you really thought so; because, being a Mugwump, you naturally took the wrong side of everything.

HAY TO ADAMS.

Newbury, N. H.

September 13, 1892.

MY DEAR HENRY :

I have just received your letter of the 30th August and write a line to catch you before you 
leave the merry Dee side; that is, if you Dee side to come and confront the perils of quarantine and the darker dangers of the interviewer. Poor $\mathrm{G}$ - has been something like a fortnight on board a pest-ship, exposed to constant fumigation and the presence of a lot of actors brought over by $\mathrm{A} \longrightarrow \mathrm{P} \longrightarrow$ to make our autumn gay. Among them is a flamboyant young woman named $\mathrm{L}$ $\mathrm{C}-$ - whose departure draped the London Music halls in mourning, who has crossed the ocean to sing for us Ta-ra-ra-boom-de-ay. I am sure $\mathrm{C}$ __ can sing better.

They have as yet kept the cholera out of New York. Tammany is doing its best because the Grey Spectre would play havoc with the Democratic vote if it ever got a foothold. Before you sail, you will know what is best,-to stay in the sanitary air of A-, or come home. There is no panic over here. I do not think the matter is much discussed. ...

We have had a lazy and peaceful summertwice brightened by the presence of celestial visitors. For did not the $\mathrm{C}-\mathrm{s}$ come for two days, to our delight and amazement? Dwas grumpily good-natured, and la Doña was radiantly lovely. They pretended to like the 
place, and commissioned me to ask the price of farms. I am doing so, and discovering that their visit has put everything up fifty per cent. I am the only human being that has bought an acre of land in the place for forty years,-yet the auri sacra fames so rages in the autochthonous heart as to convince them that $\mathrm{I}$ and my friends are going to buy all their bogs at a million an inch.

.... Hurrah for $\mathrm{H}-$ ! There is nothing like taking your medicine with a good grace.

\author{
HAY TO ADAMS. \\ Winous Point Club, \\ Port Clinton, O., Nov. 9, 1892.
}

MY BELOVED MENTOR :

I slew with my gun to-day a dozen of ducks. I divide them between you and Mrs. C_- and send with each moiety a double portion of love. Think of me as sitting all day in a punt, half the time in rain, and the other half in snow; all the time in a fierce east wind; trying to warm my poor heart with the thought of the charming destinataires of my game.

Woe is me for my unhappy country, which is 
to struggle on under the double infliction of a stuffed prophet and a stuffed ballot box. To think that you should say your Democrats were poor politicians! A party ruled by Tammany unprovided with practical politics! Ah, Henry of my soul, what do you tike me for!

.... But as to me it matters little. We must pay double taxes because a $\mathrm{C}$ - blackguard of your party so wills it. But I shall economize by breakfasting with you, and even things up in that way. ...

HAY TO ADAMS.

New York.

Nov. 25, 1892.

MY DEAREST BOOM DE AY :

I have my opinion of a Mugwump who will sneak off to Paradise just before I am expected in Washington. But go to your halls of dazzling light-I would do the same thing if I could.

As for me, I came on here to chaperon my babes through their Thanksgiving holiday, which was not long enough to allow them to go to Cleveland. Yesterday, coming back from the ballgame where I had sat for six hours or so in a 
November gale, and looked at twenty-two young men trying to kill each other in the interest of sound Presbyterian learning,-I found Mrs. $\mathrm{H}$ — with the younger shrimps at the $\mathrm{B}-$ ! The desire to look upon the faces of her offspring had been too much for her, and she had taken a short leave from her duties as sick-nurse in Cleveland, and travelled six hundred miles to spend the day with them. She goes back Monday, after leaving them at school, and I go to Washington to begin to rummage for my winter's drudgery. I should be awfully tempted to pursue you to "those yellow sands," but I must be ready to go West at an instant's notice.

$\mathrm{K}-$, too, arrived here yesterday from Chicago, where he has been to see his phosphate conspirators. He seems quite fit; but why does he still think of that Bureau? There has been an election, and the powers of light are of no more inflooence in that country.

Cast me not utterly out of your affections in that lethean abode of tranquil delights. When catching the turquoise-legged crab, when pacing the shimmering sands, when regarding the mild moon, think how much happier you are than me, and be thankful. 


\section{HAY TO $\mathrm{H} \longrightarrow \mathrm{H} \longrightarrow$.}

Washington, Feb. 5, 1893.

MY DEAR $\mathrm{H}-$ -

Here is the programme of the beautiful concert Mrs. W- gave the other evening. It was one of the most delightful concerts I ever heard.

The drawing room was filled with folding chairs which had a habit of suddenly collapsing when the ladies sat down. These successive crashes made the early part of the evening very gay to those who, like your mother and Mrs. $\mathrm{N}-$, had prudently taken possession of sofas in the beginning.

There are two more $\mathrm{H} \longrightarrow \mathrm{s}$ (quite pretty ones) at Mr. A—s'. They came to make him a visit but have suddenly concluded to go with him to St. Helen's where the $\mathrm{C}-\mathrm{s}$ now are. They, the $\mathrm{C}-\mathrm{s}$, accompanied by the two younger $\mathrm{P}-\mathrm{s}$ and $\mathrm{C}-\mathrm{H}-$ A roaring, rollicking party altogether.

$\mathrm{C}$ - is languishing for a letter.

Yours,

El Dahdi. 


\section{HAY TO ADAMS.}

\section{Washington, Feb. 11, 1893.}

MY DEAR ADAMS :

One who has made Lafayette Square as desolate as you have done has no right to be as happy as you are. If it were not too much trouble, I would punish you by writing a long letter. But I write just now to send you the enclosed I from yesterday's paper, which shows clearly that you are a Mahatma of uncommon power, and that being in two places at once is no joke at all to you.

It was a nice dinner tout de même. Miss M- was extremely pretty and bien mise; talked enough and not too much; and altogether showed herself in every respect worthy of her lofty good-fortune in arriving so young at your table. B- was sweetly naïf and Tartar, and the rest of us were as usual.

This town is the dry-suckedest orange you ever saw-till you return. It is pathetic to see our little attempts to be gay. . . .

$\mathrm{G}-$, it seems settled, is to go into your government. Considering he has been in the 
last six months a Republican, a Populist and a Democrat, he enters the Cabinet with no nonsense about him. ...

\section{HAY TO ADAMS.}

Washington, Feb. 20, 1893.

MY DEAR ADAMS:

My mother, who attained her 90th year on the seventh of this month, died the day before yesterday. She had been failing for some time, but with that unselfish fortitude which marked her whole life she forbade my brother and sister to send for me, and died at last without moral or physical trouble. All the rest of the family were there, or within easy reach. I am so far away, and there are such interruptions of travel by storm and flood, that it is useless for me to attempt to get home, even for the funeral. This is an added misery - though it is as illogical as all remorse.

Do not imagine I am writing to extort from you a letter of condolence. I do not want one from you. You did not know what she was to us.

I mean nothing in particular by writing. All 
I do of late is an inert yielding to the momentary impulse, or an equally inert resistance to it.

I congratulate you again on being where you are. Washington is in its vilest mood. The ground is covered with snow, and a vicious, cutting wind is blowing.

HAY TO ADAMS.

Washington, D. C., March 6, 1893.

MY DEAR H- :

.... B- P- told me yesterday you could be reached at Savannah. But what does he know? He came into lunch yesterday and told us of your Odyssey. Afterwards, while I was out for a walk, he came back and scared my wife into giving him all her Peter's Pence; he pretended it was for you. $I$ knew he had been playing poker for an office with $\mathrm{C}$ - and had lost. If you don't hurry back you will get nothing. There are several thousand office seekers of your sort camped about B-_'s house. Some dozens come hourly to me, thinking I am Band swearing when they find I am not. Brass bands played ribald tunes under his Presbyterian 
windows all day Sunday! It is a pretty town you and your gang have made of it.

Has anybody told you that G-, L$\mathrm{F}-$, and $\mathrm{A}-$, a Fijian friend of yours, have been at your house? They had a dinner there Friday,-the $\mathrm{G}$ - $\mathrm{s}$ and the $\mathrm{B}-\mathrm{s}$-the innermost $\mathrm{C}$ - circle. Come back! Now is your chance!

I have not seen Mrs. C-. She had a terrible journey. $\mathrm{D}$ - waited at the station in a crowd of roaring Democrats from eleven till four in the morning. $\mathrm{P}$ - says she seemed very much fatigued and broken up.

What a charnel house it all is! You and I, the $\mathrm{L} \longrightarrow \mathrm{s}, \mathrm{R} \longrightarrow \mathrm{s}, \mathrm{C} \longrightarrow \mathrm{s}$ all at once.

HAY TO ADAMS.

New York,

March 9, 1893.

DEAR ADAMS:

I got your letter from Tampa Bay this morning. I wrote to you some days ago directing my letter to Hotel de Soto at Savannah. If you never get it-no matter! There was nothing in it. 
I wonder if you will run across $\mathrm{K}$ - in Florida. He is there; and as you never find him where you expect him, you might find him where you didn't.

As I left Washington Tuesday morning, Mrs. $\mathrm{C}$ - stopped my carriage on $\mathrm{H}$ Street to tell me her mother was worse. One could hardly wish her to survive this last disaster.

It takes a day or two in New York to bring home to me my age and loneliness. I had my $\mathrm{W}-\mathrm{U}-$ meeting yesterday and the children are coming down to see me to-morrow. Today is therefore a day of blankness and nullity which is positively enlivened and made bearable by a headache. The rain falls in torrents, and the streets are a waste of slush. All the $\mathrm{K}$ men are in Washington asking $\mathrm{C}-$ for foreign missions.

When you get back to Washington, you will be in the very focus of grandeur. $\mathrm{O}-$ ! and Joe Joe Q- ! and now $\mathrm{H}-\mathrm{S}-$ says he is your cousin. I shall rely on you to save my neck from the axe of $\mathrm{A}-$ and the rope of $\mathrm{G}-$ - 
HAY TO ADAMS.

Cleveland, June 9, 1893.

MY DEAR ADAMS :

Life is so langweilig without you that I must sit down though I have nothing to say, and tell you howdye over the brine. Our trip to Swas a dazzling success. The weather was delightful; the apple-blossoms were at their loveliest, and everything went so well that even $\mathrm{C}$ __ laid aside his fin-de-siècle melancholy and was gently gay.

I came down to New York to get the children, while Mrs. $\mathrm{H}-$ and $\mathrm{C}-$ more sensibly skipped off to $\mathrm{C}$ - It was scorching hot and $\mathrm{H}$ - fainted in the dressmaker's hands, but she soon righted, and we made a pleasant journey here. . . . Next week we start for Chicago. We heard the most dismal news of our tavern; that it is not finished and never will be; that the elevators are unborn; that the walls suintent Chicago water and malaria-and verily we are sore beset. Add to that, every business house in $\mathrm{C}-$ seems aux abois; a lame darkey has just left my office after making me help buy him a $\$ 12$ horse; an Englishwoman 
from Allahabad without an $h$ to her back, has done me out of a month's rent in the name of sweet charity; the tax-gatherer sits on my doorstep in permanence; and $\mathrm{C}-$ and the $\mathrm{M}$ boys fight from dawn till dusk.

I live in sleepers till I sail. Write me a letter to the $\mathrm{K}$ - Club which I may find there on or about the 10th of July, or as much sooner as you like. You could catch me here up to the 1st of July.

I dined with H. R. H. Eulalia at the R-s. $\mathrm{W}-$, with a heart overflowing with kindness, introduced me to all the Castilians and Bourbons as the author of a book about Spain which they really ought to read, etc.,- - unconscious, the good $\mathrm{R}-$, that my unhappy little volume treats the august family of Spain as a set of pas grandes choses from Wayback, who have no place outside of penal and reformatory institutions. Still, if they can stand the hymn of Riego at the BEmbassy, they can stand an abusive book they have never heard of. 
HAY TO ADAMS.

Cleveland, July 3, 1893.

MY DEAR ADAMS:

....Well, we have done our Chicago, and have not a word to say about it. We were all knocked silly. It beats the brag so far out of sight that even Chicago is dumb.

To-day I got a telegram from that impudent $\mathrm{K}$ - asking me when we shall be in New York. If I tell him he will start for Africa or Alaska, to be out of the way when we come.

$\mathrm{I}$ hope $\mathrm{H}-\mathrm{W}-$ is safe for a month or two, as G- is doing his World's Fair and $\mathrm{C}$ - is dozing the happy hours away at B$\mathrm{B}$ - And perhaps in the fight over the dead body of the Dollar they will forget all about him. Oh! Criminy Cracky! but it is dull over here! Nobody can call his day's marketing his own. A Blue Funk is in the air, and silver gets all the blame-when it is only a drop in the bucket. . . . 
HAY TO ADAMS.

London, July 22, 1893.

MY DEAR ENRIQUE :

Your letter from Zermatt has this moment reached me, and my altruistic soul is half assuaged of its grief at not seeing you in England when I think of you "lolling on silken sofies in the gilded palaces of royality," and contemplating the Alps in the eyes of the all-beautifullest $\mathrm{R}$

We arrived here Thursday night. We had a dull voyage - there was nobody on board worthy of a place at your breakfast-table; and the weather, while not rough, was wet and muggy all the way. We got to Liverpool Wednesday evening too late to come on; so slept enjoyably in a shore bed, and came on the next day. They gave me a car to my own cheek without charge,I don't see how these innocent English roads pay their dividends when we, who treat the public with deserved contempt and outrage, can't make both ends meet.

Our plans, which you do us the honor to ask for, are vague but simple. We stay here till August 1. Then go to Scotland for a week or 
two-come back here and start for Paris about the 1st of September. Two or three people have kindly asked us to visit them, but it seems so impossible to bestow our little menagerie of venomous wild creatures that we shall have to decline everything of the sort, except perhaps a few days at $\mathrm{T}-$, whither $\mathrm{H}-$ and $\mathrm{D}-$ will accompany us.

I hope we may see you in Paris-though my hopes are not too presumptuous or robust. Perhaps you may get enough of the Alps by that time-perhaps you may get nostalgique for the Palais Royal.

I had an amusing talk with $\mathrm{W}$ - this morning-far too amusing to put on paper. $\mathrm{He}$ knows nothing as yet of his salvation; he has heard $\mathrm{L}-$ is after his scalp.

Good-bye, and heaven be better to you than you deserve!

\section{HAY TO ADAMS.}

$$
\text { London, Aug. 29, } 1893 .
$$

MY OWN AND ONLIEST :

I got here an hour or two ago from Scotland, and found yours of the 12 th on my table. I am 
glad you are alive, and able to pay for your champagne-and mine also-I don't drink much. I got letters at the same time from Cleveland and New York full of dolor and profanity. People I owe want their money, which they won't get it, Hallelujah! People who owe me say they will be $d-d$ if they pay-which I think quite probable. But seedtime and harvest will follow each other. There will be marrying and giving in marriage. Statesmen will lie and be lied about. Speculators will rob and be robbed. And pretty women and good wine will still be found at the old and reliable stand, No. - H. Do not forget the number! No connection with the shop over the way.

We feel as if we had been out of the world for the last month. We had a peaceful ten days at T- The old Laird and Lady were not well, of course, but wonderfully plucky and bright, and did not let us feel that they were suffering or that we were in the way. I had a sharp attack of rheumatism which stopped my breathing for 24 hours. But I astonished the little $\mathrm{T}-$ doctor by getting well in two days. I made the useful discovery that breath is not necessary to life. We spent a day at Glen Tana, and then pulled 
out and abode a few days at Fyvie. $\mathrm{H}-$ and $\mathrm{D}$ - were with us, and enjoyed their stay in that beautiful fortress as much as they ought. $\mathrm{H}$ - was deeply disgusted at not being told until just as we were going away that she had been sleeping in the ghost-chamber, haunted by the lively spirit of Lilias Drummond, the Green Lady. I suppose the ghost thought if she tackled a Yankee girl, she would get the worst of it. We went on from there to the $\mathrm{A}-\mathrm{s}$, who were on their heads in sixteen kinds of a hurry, getting ready for Canada. Sir J- was there, and went with us to Aberdeen to say good-bye. I was much touched at his emotion at parting. The same thought was doubtless in both our minds that we were saying farewell for the last time. Few and evil are the days that are left to both of us.

.... Good-bye! I agree with you about the future. But I distrust my own black spectacles. Things can't be so bad as I think. . . . . 
HAY TO ADAMS.

Aix-les-Bains, Sept. 25, 1893.

MY DEAR GLOBE-TROTTER :

Your letter of the 8th has just reached me, having been forwarded twice and lost a day each time. It represents you in such a frog-hopping attitude that I am not sure this will ever find you. So I will make it short, and not repeat my error of sending reams of science and morals to you at Tahiti, which arrived, as old as Aristotle, after you had been years in Washington.

I am here because, like a fool, I took all my friends' advice, who told me it would be good for the rheumatism. I have got steadily worse every day since I arrived-but I calculate I can stave off your friend Thanatos for ten days more, the period of my cure. The doctor tells me I have Thermal Fever, the result of the baths. It is not much worse than cholera, so I will grin and drop the subject. When you get this I will be in Paris or Hades. . . . . 


\section{Aix-les-Bains, October 2, 1893.}

Your letter of the 21st of September arrived here to-day and found me in most uncommon dumps. My fool of a doctor has discovered another mortal malady in me, which tickled him very much, and disgusted me to such an extent that I am waiting only to see whether to-morrow is a fine day or not. If it is, I am going to the Grande Chartreuse near Chambery; if it is not, I am going to Paris, and the doctor may go hang. I have wasted three weeks here. Nothing is changed; there is only one humbug the more.

But you - the expectancy and rose of the Democratic party-what has man thee, thou artless one, gedone? Having a mind of your own, young man! when the President has spoken, will bring you to no good end. All men of virtue and intelligence know that all the ills of life,-scarcity of money, baldness, the comma bacillus, Home Rule, J__ - $\longrightarrow$, and the Potato Bug,--are due to the S- Bill. If it is repealed, sin and death will vanish from the world, .... the skies will 
fall, and we shall all catch larks. This un chasqun scait; therefore, stop gunning at your pastors and masters, and help $\mathrm{C}-$ and $\mathrm{V}-$ in the good work. Then cut the whole thing, and come over, and do the little theatres with me.

The very postmark of your letter makes me homesick. What an idiotic thing it was for Darby and Joan to leave their own friends and go hotelling about the world. $\mathrm{H}$ - gets a little fun out of it-not much. She would a thousand times rather be in $\mathrm{W}-$, or even $\mathrm{C}-$ And as for me, I am bored out of my five little witsand the worst is, I cannot howl in my misery without casting a gloom over my compagnons de voyage. You-happy-can go where you like and see the Taj or the Daibutsu or Prester John or the Pope. I wish you no harm, but if you are fool enough to leave home, I hope I may profit by a sight of your geistreich face in Paris before December 1. Mrs. $\mathrm{H}-$ and $\mathrm{H}-$ would send their love, so regard it as sent. If the $\mathrm{B}-\mathrm{s}$ are in the dêche, give Miss $\mathrm{H}-\mathrm{my}$ love. We paupers must stand by each other. 


\section{HAY TO ADAMS.}

Paris, November 3, 1893.

\section{MY BELOVED :}

I have no idea where you are or what you are doing, but from force of habit I shut my eyes and shoot a letter at you from time to time, feeling that it makes no difference whether you get it or not. This one is to tell you that we are going to skedaddle from this gay and wicked city, (this is the formula-for my part I have found it as dull as a dead rat and vitreous as a mugwump), on or about the 20th of the present month, for a little meander of four weeks in Spain. Then we come back here for a week, give the shrimps a Christmas dinner, and betake ourselves to Italy, with what appetite we may. This is our modest programme, and I give it to you as is my bounden duty. It may not be carried out, for I get up each morning with the impression that I will probably drop to pieces during the day. But that is all in the day's work, and we shall go if I can toddle.

I can see you are having so much fun in Lafayette Square with your B-s and your L_— $\mathrm{s}$ and Silver Bills, that nothing will tempt 
you to come away-so I will stop importuning you. Did you see $\mathrm{H}-\mathrm{W}-$ ? You ought to be ashamed of yourself for bouncing him. ... .

We went the other day to see Sardou's "Madame Sans Gène." It would have amused you. It is in your period, and Napoleon, in full uniform, stands on his hearth-rug and abuses his sisters Elise and Caroline, like a coster. There are a lot of little plays at the small theatres, but it is no fun to go alone, and so long as you shirk your duty I shall not see them.

HAY TO GILDER.

Paris, Nov. 20, 1893.

DEAR MR. GILDER:

Your letter of the 4th reached me only to-day, too late for me to write anything for printing in your paper. Even if I had received it in time, what I could have said would have been little to the purpose. I imagine that most of your responses must have been as monotonous as a chorus of angels in glory. The Chicago Fair was, in almost every respect, the greatest uni- 
versal exposition ever seen; but in architectural beauty, and in the felicity of the disposition of its principal features, it so far transcended anything which the genius and the devotion of man have ever yet achieved, that it will probably be remembered and celebrated more for the incomparable splendor and loveliness of the ensemble than from any merit of details; the particular claims to admiration, great as they were, are likely to be neglected in the overpowering impression of grandeur and beauty made by the whole.

Perhaps the thing that has most impressed me has been the entire ignorance of Europe in regard to the matter. The most beautiful sight that has ever gladdened the eyes of humanity has shone for six months on the shores of Lake Michigan, and it is hardly too much to say that the rest of the world knows nothing, and refuses to know anything, about it. When we speak of it, we are met with incredulity and a more or less polite lifting of the eyebrows. In the annual revue of one of the Paris theatres, it is represented as a four gigantesque. In this country where they are continually talking of our worship of the Dollar, the Chicago Fair is summarily clismissed from notice as a failure, because the stockholders made 
no money out of it. They order these things better in France.

But it is not philosophical to quarrel about such matters. Contemporaneous history gives no account of the Crucifixion. Nobody knows anything about Shakespeare. The Chicago Exhibition has fared better, at least, than these two events, the most important in the history of the human mind. A great many millions of Americans have brought away from it higher and nobler standards of beauty and grandeur than they ever had before.

\section{HAY TO ADAMS.}

Paris, December 20, 1893.

MY DEAR HENRY :

It has been so long since I heard from you, and so long that I have waited and delayed writing hoping every day for news of you, that life is growing very gray and sour. This morning I read in the little $H-$ that $\mathrm{W}-\mathrm{M}-$ has been made Ambassador at R-, and I can't help hoping that you will come over with him and chirk us up with the life of your countenance. 
The Old Man is improving. $\mathrm{V}-\mathrm{A}-$ was a good appointment-M- is better. I hope he will accept, for C C can't be expected to keep up such a crescendo.

But what a deplorable mess they have made of the H- matter! Our good Sir John is greatly pleased with that and with all $\mathrm{C}$ faits et gestes. I do not gainsay him. It is bad taste-I see it in C- and $\mathrm{G}$ - - to blackguard your government's foreign policy before strangers.

We got back from Spain a day or two ago. To-morrow $\mathrm{A}-$ and $\mathrm{C}-$ are coming on to spend Christmas with us; and immediately afterwards we pull out for Italy. Tell $\mathrm{M}-$ to hurry or he will not find us there. We shall be perhaps a month in Italy, and shall then run over to Cairo for a few weeks. ....

MAY TO ADAMS.

$$
\text { Paris, Jan. 1, } 1894 .
$$

I can make no better use of the first minutes of the New Year than in renewing my allegiance to you. Wherever this finds you, in W-, 
St. $\mathrm{H}-$ or $\mathrm{N}-$, may the heavens be blue and the air auspicious, for wherever you are, you will deserve better treatment than you get.

. . My two poor shrimps came to pass Christmas with us, but were both taken down with tonsilitis and passed their holidays in bed. We are sending them back to $\mathrm{D}$ - to-day relatively well and very cross. I do not blame them. I think the crying sin of the age is the eruelty of parents.

We pull out for Italy to-morrow. We have given up our Nile journey, as our old friend $\mathrm{L}-\mathrm{M}-$ was so seriously ill. He is decidedly better, but not up to any fixed plan yet. We shall go loafing at our ease through Italy, and perhaps spend all our time there until Spring. I am bored out of my sweet life, but try to keep it a secret from $\mathrm{H}-$. She is considerably my elder in most things, and I am constantly afraid she will discover the emptiness of the world before we get back to $\mathrm{W}$ -

We all send our loves and best wishes for this year and all the years that are to be.

I never imagined I would be sorry for anything that happened to $\mathrm{G}-$ But this $\mathrm{H}-$ 
business is too painful. I feel as if it had happened to all of us.

HAY TO ADAMS.

Rome, January 21, 1894.

I am willing to stand even your unprincipled vituperation, to get a letter from you. But are you crazy? I have written you a million times, by actual count.

We are in Rome, and it is grotesquely melancholy to see how incapable of enjoying it I have become in the time it has taken to get here. Take warning by me and stop globetrotting, now that you are young and gay.

We were frozen stiff on the way here. Turin was knee-deep in snow. Genoa was swept by a murderous mistral. I gave up and went to bed at Pisa-but Florence picked me up and smoothed the creases out of me in fine style. I think on the whole when you get ready to open your heart and set me up in life, you may buy me the Strozzi Palace. With weather, and art, and architecture one can worry along. We have all 
three here, but in addition we have a lot of American bosom-friends, and that complicates matters. $\mathrm{H}-$ and I went to the grand function at the Pantheon, where they had a magnificent mass to get old Vict. Emman'. out of his well-earned purgatory. As we stood in the gorgeous gloom of incense smoke and flambeaux in a suffocating crowd, I heard a familiar voice at my shoulder say- "Well, I did not expect when I saw you last, to see you next in the Pantheon in a dress coat at ten o'clock in the morning." It was $\mathrm{P} \longrightarrow \mathrm{B}-$, also in a dress coat and white cravat, as our "etiquettes" prescribed. And coming out, I heard more English, or what passes for English, than Italian.

$\mathrm{P}$ $\mathrm{V}$ - could not do better than take it if it is practicable. You hardly know whether you are in New York or Washington on a Saturday afternoon at the Legation. I saw there yesterday most of the ghosts of our diplomatic body. By the way, S- $\mathrm{R}$ - passed through here a little while ago leaving a wake of sweetness and light behind him. What will he do when he gets to $\mathrm{W}-$ and finds you and the $\mathrm{C}-\mathrm{s}$ away? If he is sensible he will follow you south$18^{2}$ 
ward. I am delighted to hear you expect to take $\mathrm{K}-$ to the West Indies. It will not hurt you, and will do him no end of good. It would be almost worth an attack of meningitis to take a trip to the tropics with you. Comfort him and jolly him up. Saturate him with sunshine and sapodillas, and get him to come and live in W- like a man and brother. Now that his affairs have gone to everlasting smash, we can set him up in a bijou of a house, and give him corn and wine and oil to educate us in viscosity.

$\mathrm{We}$ are here for a few weeks. If $\mathrm{H}-$ insists on Egypt, to Egypt we go. But there are a few girls and dudes of her species here and I hope she will like it well enough to dawdle along here till it gets too warm for the Nile. . . . . There is something to do every day. All I lack is a stomach to eat and drink withal, eyes to see withal, ears to hear withal, and a heart to flirt withal. If I had these, I would get on in Rome very well. As it is, I sigh for Lafayette Square the lieben langen Tag. 
HAY TO NICOLAY.

Rome, Jan. 26, 1894.

DEAR NICOLAY :

I have been intending to write to you for months, but our plans have been vague, and my laziness grows on me year by year. I have concluded not to come home until next June. The younger children are established at a sort of school-family at the Chateau D_-, near Cabout an hour from Paris - the residence of a Marquise de $\mathrm{S} \longrightarrow \mathrm{C}-$, a lady in reduced circumstances with a fine place which she is unable to keep up without outside help. She has a large family of daughters-the older ones teach the younger-and the thing seems to be going on very well. D- has gone back to school at $\mathrm{D}-\mathrm{F}-$, and we have excellent reports from him also. He enters Yale in the Fall.

$\mathrm{H}$ - is getting so much out of this journey in an educational point of view, that I think best not to cut it short, and not to come away and leave her and her mother to go it alone. This is the most important and interesting year of the child's life, and I ought to be on hand to give a 
little direction, not only to her studies but to her earliest contact with the world. It is hard lines for the old man to sit up till eleven o'clock and then go out to a ball, and stand about three hours, wishing I was dead and cremated. I wrote "years" just now, and ought to have let it stand. It seems that long. But she is picking up things every day that will always be of interest to her, and I think this preliminary canter before she "comes out" will do no harm. We are busy sight-seeing all the morning, and years would not be enough to see everything that is to be seen in this wonderful town.

We had a delightful and profitable trip through Spain-the most interesting thing in Europe, I think, is Northern Spain beginning with Toledo. There are good hotels now and reasonable railroad connections, so that the journey is easily made.

I say nothing about our work because I don't quite see what to say. It is so dismal a time to be launching a new book that I imagine the $\mathrm{C}$ - people will be in no hurry about it. If they are, and want the work pushed, I give you carte blanche to do anything you think best. You can hire a substitute for me and pay him or her a princely salary at my expense-and I will make 
it right if I find I have anything left when I get home. My letters are full of disaster and gloom. I only fear the country will make the usual effort and pull itself out of the slough about the time of the next Presidential election.

Mrs. $\mathrm{H}-$ and $\mathrm{H}-$ send their love to $\mathrm{H}-$, and I am always,

Sincerely yours.

\section{HAY TO ADAMS.}

\section{Rome, February 5, 1894.}

. . . Since I wrote you last, nothing has happened to me, save that, impelled thereunto by a daughter who cares more for her amusement than my repose, I have been to Court and made a leg to the Queen. I do not know how I acquitted myself, but trust that, in imitating as well as I could remember the reverences $I$ have seen you and $\mathrm{K}$ - make to the beautiful and the great in H Street, 1603, I did you no discredit. Her majesty was very gracious-and afterwards expressed herself in regard to my family in language I have carefully kept secret 
from my wife and daughter for fear they should shake me and "go off with a handsomer man" from mere considerations of homogeneity.

Rome is a hopeless job. We have been here nearly a month, and have scarcely as yet nibbled the edges of the things one ought to do. De guerre iasse we have given it up, and are going to Naples in a few days. $\mathrm{S}$ - told me the other day that in a dozen years of Rome he had not seen it, and had also chucked up the job. The present régime, I admit, is making the sight-seeing business easier year by year, destroying the picturesque old town, and building a cheap and nasty imitation of Paris on the ground. But they are too late for me. There is still enough Rome left to put me in my little grave, if I undertook to see and understand it.

We buried poor C_— W - last Wednesday in the Protestant Cemetery, laying her down in her first and last resting place-a thoroughly-good, and most unhappy woman, with a great talent, bedeviled by disordered nerves. She did much good, and no harm in her life, and had not as much happiness as a convict. . . . 
HAY TO WHITELAW REID.

$$
\text { Rome, Feb. 7, } 1894 .
$$

MY DEAR REID :

We have had a month of Rome and our day of dust and ashes is come. I write to you on Ash Wednesday, not with any idea of mortification of the flesh, but rather to prolong the agreement of the reason a little. We have had a very pleasant time of it. The $\mathrm{P}-\mathrm{s}$ have been most efficiently kind, and $\mathrm{H}$ - has found other young folk of her sort and everything has gone as delightfully as possible. If I had a new head, and a new liver, and various other vital organs brand new, I should have made more use of my time. But as it is we have seen most of Rome, been to a lot of pretty parties, made our reverence to the Queen, who was very gracious and charming, and tomorrow we pack our trunks for Naples with consciences void of offence. Where we shall go after a week or so of Naples, we do not know, we float at the will of the wind. It may be Greece or Egypt or the northern cities of Italy. I leave it to Mrs. $\mathrm{H}$ and $\mathrm{H}$

They decide things 
by the mysterious process of feminine logic, and generally come out right.

$\mathrm{P}$ _ has made an excellent minister. Everyone speaks well of him, Americans and Romans alike. He lives in handsome and generous style, and treats everybody apparently with tact and good judgment.

Things seem to be going our way so universally at home that I cannot help fearing a turn of the tide. I take great interest in my $T-$.

\title{
Faithfully yours.
}

\author{
HAY TO ADAMS. \\ Florence, Italy, Europe, \\ March 9, 1894, A. D.
}

MY ANGELICAL DOCTOR :

It is sinful to think of your having such a good time in the tropics without me. I presume you have not endorsed a dress coat since $\mathrm{T}$ $O$ nimium fortunatus! Perhaps you have shed the frivolity of dress entirely and reverted to the buff of your Pomare-nian ancestors. At all events you are having too good a time to suit me. 
With the gradual progress of age I have lost all my vices and most of my passions, but envy stili survives, and the thought of you and $\mathrm{K}$ enjoying the subtropical days and nights of the Great Antilles is too much for me.

My annals, since I last wrote to you, are appropriately short and simple. We went back to Rome for a fortnight after Paestum and Sorrento .... and found the Yankee colony standing on its little head about the departure of $\mathrm{P}$ - and the arrival of $\mathrm{M}$ - It is a loyal little colony, and likewise fond of a diet of toads. It wanted to be sorry $\mathrm{P}$ - was going and to be glad M- was coming, and its perfectly sincere efforts to weep with one side of its mouth, and laugh with the other, were very touching. We had a big dinner at which both the diplomats made good speeches. Baron — was of a comic unspeakable trying to talk English,-and later in the evening $\mathrm{V}-$, who was far gone with the rosy God, asked me if I ever met a friend of his, a Colonel L_- who wrote a Life of Etcetera.

And so your old friend $\mathrm{G}$ - has had to throw up the sponge at last in his bout with Chronos the Slasher. We are all growing old except $\mathrm{G}-$ and the Mugwumps; they will 
remain eternally about nine years old-nine or eight and a half.

Why do I write these futile notes to you? Simply to get an answer. I hunger for news of you.

\section{HAY TO ADAMS.}

Dresden, 27 March, 1894.

ENRIQUE DE MI ALMA :

If you keep to the plan referred to in your esteemed favor of the 27th February which has just reached me, you will be nearing your refined Christian home in Lafayette Square about these days. Your letter was a great comfort. The slight tribulations you met with on your way to your earthly Paradise only whetted your appetite for the tranquil pleasures you found in your cafetal. The fleeting and evanescent ewig weibliche is far better hoped for than attainedso I do not waste any sympathy on youalls on that account. To be a month away from an American newspaper is as near an approach to the bliss of Nirvana as you have any right to expect in this world. The domestic divinity under whose 
gentle tyranny I groan takes in the $N-Y$ $H-$ of $\mathrm{P} \longrightarrow$, an American paper, with French worthlessness added, which is filled with idiotic laud of the $\mathrm{N}-\mathrm{Y}-\mathrm{H}-$ of New York and $\mathrm{G}-\mathrm{C}-$, a stout gentleman who, I believe, is a neighbor and friend of yours in Washington, with occasional references to the deputy omniscience of one $\mathrm{C} . \mathrm{N}$ —. It is almost more than I can stand.

Nothing has happened since I last wrote to you. We have driven in cabs through several towns. We have smelt incense in many churches. We have gazed on several acres of spoiled canvass and seen some good pictures. Bologna and Verona and Perugia were very remunerative, and I was almost tempted to buy the Rezzonico Palace in Venice, as I hear Mrs. R. B- B- has quarrelled with her poet-sculptor-painter husband, and wants to sell him out of house and home. But the common sense of my wife, as usual, prevailed. She says $\mathrm{W}-$ is less damp for my rheumatic shoulder; and doubts if you would come to Venice.

$\mathrm{I}$ got a letter from $\mathrm{B}-\mathrm{P}-$ yesterday saying Mrs. J- G- was in W- I shall never see that divine creature again, I 
suppose. I saw her once, you know, under your protecting care at Beverly; since then, fearing my tumultuous admiration, she never comes to W_ but when I am away.

I am impatient to get home, but what will become of me then? With my little mind gone, my eyesight and hearing going, you continually auf der Reise, and $\mathrm{K}$ - generally in a sleepingcar, "What will the poor darkey do?" I see $\mathrm{N}$ - has broken out writing endless articles about $\mathrm{L}-$ and $\mathrm{I}$ fear $\mathrm{I}$ shall be driven to my reminiscences of $\mathrm{S}$

Good-bye! Give my love and all our loves to that dear $\mathrm{K} \longrightarrow$, if he is in reach.

HAY TO ADAMS.

Paris, April 25, 1894.

MY DEAREST TAURA :

Your letter from $\mathrm{T}-$, informing me that you had once more reintegrated yourself under the flag, arrived this morning and gave me a happy day. It gave me courage and strength to go through the Champs de Mars Salon, with its 
wilderness of impressions and nudities, and dirtylooking portraits of Frenchmen smoking the cigarette. Why they cannot paint a Frenchman doing something else-blowing his nose, combing his hair, or performing some other natural function - puzzles me. Even a Frenchman must do other things occasionally. On the whole, the show is a poor one, distinctly below those of former years. The Salon of the Champs Elysées opens Tuesday, and on Wednesday we skip for London, having seen more pictures than in any previous year of our little lives.

.... I have done nothing and seen nobody since I got here-except to go to a doctor and have my ears blown out with dynamite or something every day - the effect of an influenza contracted at Berlin. I forget when I last wrote to you-I do nothing but write to you-but we went from Venice to Vienna, Dresden and Berlin. The weather was brutal, and at Vienna the piety was excessive-being Holy Week-so that the trip was not remunerative. But $\mathrm{H}-$ saw some pictures.

I am sure I have given you a thousand times our whole plan for years to come. We go to London on the 2d May, to stay, off and on, till 
the 27th of June, when we sail in your good ship II- for New York. Thence we go directly to C-..... I do not write long letters for the same reason that I see nobody, and do not talk. I am filled to the lips with the amari aliquid of age and infirmities. If I talked or wrote, I would talk or write about myself which is a loathly subject. Perhaps I will get better one of these days - and younger,-and then I may again be company for the unexacting. At present I am a bore from Boresville.

.... I see G-'s return to sanity the moment he got out of office has not escaped your eagle eye. Per contra, the moment the cynical and clever $\mathrm{R}$ - gets into the chair, he begins to make a fool of himself. His speech in the House of Lords giving Home Rule the grand bounce, was an incredible légèreté-all the worse because it was true and logical. What right has a Prime Minister to fool in public with truth and logic?

.... I shall read of the progress of Coxey's army with new interest now that I know you are in W-. Perhaps they will spare my house because it adjoins yours. You, of course, are known throughout the country as a Demociat 
and an Anarchist and an Unemployed. Your house will be safe anyhow; so you might as well stand on my steps while the army passes, and shout for "Chaos and Coxey" like a man. I hope you won't fare like Tailhade, the anarchist poet, who porter-ed a toast to Vaillant ("Qu'importent quelques vagues humanités pourvu que le geste soit beau!"), and a little while after, sitting in the Café Foyot with a lady-friend, was blown up by a bomb.

HAY TO WHITELAW REID.

$$
\text { London, May 4, } 1894 .
$$

MY DEAR REID :

Your letter from San Francisco reached me here to-day. My womankind have just driven off to Buckingham Palace in gowns whose vastness and splendor abashed me. H- thought she would like to be presented, and Mrs. Hand I, who for twenty years have avoided that function, weakly yielded and are swept into the vortex. I am to make myself look like an ape of Borneo at the next Levee. Lord, what fools we 
mortals be! Miss J- will one day lead you the same dance. The $\mathrm{M}-\mathrm{s}$ are here and are to be presented next week. M- has apparently entirely recovered his health. His cure has been a remarkable one after his five months of suffering and danger. He cannot walk much yet, but thinks that will be only a question of time and patience. He will have to learn all over again. I met E- on the street in Paris the other day. He was very outspoken--so much so, that I was afraid he did not know my politics. So I told him, but that made no difference. He spoke of your possible candidacy for Governor, and said the man who was successful in the next election in New York would be the favorite for the Presidential stakes. He took it for granted that the Republicans would win. I said the drift just now was with us, but no one could tell what a year might bring forth. He said: "I see no possible policy in domestic affairs that can regain us our lost ground. In fact, Sir, the Democratic party has got a bad case of the grippe."

We shall be here, if nothing happens to call us home, until the end of June.

My wife and $\mathrm{H}-$ - , before setting out on this solemn errand, bade me send their affectionate 
remembrances to Mrs. R- and you-so if they never get back, you may know they loved you even on the way to Buckingham Palace.

Yours faithfully.

HAY TO ADAMS.

London, May 28, 1894.

MY OWN NEXT-DOOR NEIGHBOR :

Like a ray of sunlight into the murk of London come your occasional letters of benediction. The one of the thirteenth came a day or two ago, and inade me so homesick that I wanted to start at once and catch at least a tail-feather of the vanishing spring in W-. But I am chained to the stake, and bear-like must fight my course. I never imagined I possessed so much patience and unselfishness. I think I must take office again when we get youalls out. I, who am old and cross and ugly and sick, besides having the rheumatism and being stone-deaf and sand-blind. I go out daily to lunch or dinner, and semi-claily to tea-the soul within me withering for pure borebecause I hope a little glimpse of what London is $19^{2}$ 
like may amuse $\mathrm{H}-$, or at least be something to have known hereafter. The enfant de fin de siècle is hard to amuse-but perhaps the meminisse juvabit will be the best hold after all. She does not care for great functions, except to put them in her little diary. She is bored by the great and good, the few specimens she meets; but she does uncommon like to come across a boy from $\mathrm{C}$ - - which she does every five minutes from Naples to Liverpool_or a girl from $\mathrm{D}-\mathrm{F}$ There is one hopeful sign about her. She does not object to standing with me in a corner of a palace, and seeing the glittering show pass by.

We had an amusing dinner to the "C___." Admiral $\mathrm{E}-$ was scarcely mentioned or thought of; but when it came his turn to speak he waltzed in like a true-hearted Tar, and took the whole thing to himself, and made a charming and absurd speech which captivated the house. $\mathrm{M}$ - was a succes d'estime beside him. But the currency of $\mathrm{M}-$ is something amazing. $\mathrm{He}$ is continually referred to in the newspapers and in conversation as the first historian of the century. $\mathrm{He}$ is persecuted with invitations from princes and publicists. They can't have read 
his books; good as they are, they are long and serious; and the world of princes does not read. It is a case of qu'on se le dise, I imagine.

How I wish I could go with you to the Yellowstone! Mrs. H- says I may-but I am old and lame. .....

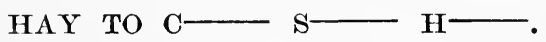

Highbury, Moor Green, Birmingham, June 7, 1895.

Well, here $I$ am at Highbury, and it is a very pretty place. The house is very large, built around a great central two-story hall, something like A- Hall, but larger. The view is very fine over hills and hollows, and the grounds themselves are beautiful and, of course, in the most perfect order. The rhododendrons and azaleas are splendid in color and luxuriance, though the season is late on account of the cold.

I came up in a separate compartment from all the rest of the party, and on arriving at $\mathrm{B}-\mathrm{I}$ was delayed a little attending to my luggage, so that the omnibus was filled and I took a cab and 
came out in solitary grandeur. Highbury is several miles from the city of $\mathrm{B}-$; so that when $I$ arrived the party were assembled in the drawing room around the tea table. It consists of Lord and Lady L_-, Sir L_- and Lady P-, Sir John and Lady L-, and a C- of the Foreign Office, young V- $\mathrm{H}-$ and Major $\mathrm{P}$ — of our Legation. Lady $\mathrm{P}$ - is pretty and attractive. I had never met her before though we have so many friends in common. We went out for a little stroll in the grounds. Lady L- very kindly introduced herself to me, saying, "Lord L_ said to me the other day, 'why haven't you asked him to dinner?' I said because he hadn't introduced you to me." She seems very nice and simple. The two younger $\mathrm{C}-$ girls are very pretty and sweet and school-girlish in manner. Mrs. J- is the same as ever and seems in delightful relations with the children.

Dinner was at eight and the company assembled in the great central hall where a nice fire was blazing. It was a pretty sight to see them coming down the great staircase in their brave gowns and jewels. I took in Lady $\mathrm{P}$ __ and sat between her and one of the younger $\mathrm{C}-\mathrm{S}$. The table 
was, of course, magnificent with orchids and Salviati glass.

You ought to have heard Lady $\mathrm{P}$ - go for the - - s. "The girl is pretty and the mother is very well. I never heard her say any of the stupid things attributed to her. But there isn't a natural note about either of them. They are regular campaigners. They care for nobody except those who can help them into smart company. It is 'Dear Lady $\mathrm{P} \longrightarrow$ ' or 'Dear Lord Something.' I have helped them some, and glad to do it-but I get sick of them." Then, turning to me, she launched the everlasting question, "I suppose it is true about the money?"

I forgot to tell you that Lady J-, at the _.'s, put the same question, and then said she would like to marry her to her brother, a colonel in the guards, aged forty-two, very handsome and clever. Mrs. _ told me a lady of rank asked her the question directly, "Are you not very rich?" to which Mrs. _ responded, "I have never been asked that question before and hardly know how to answer it," which I thought a very neat reply.

They had a glorious time at the State Ball. I called the next day and found poor Mrs. 
suffering dreadfully with inflamed eyes, from the glare. She had one of M-'s beefeater hats on to shade her eyes, and looked very unhappy, though triumphant. I thought, " Il faut souffrire pour etre swell."

I do not think the $\mathrm{C}-\mathrm{S}$ have been having a very gay time. I have asked them all to go to the theatre Monday night to see the Enfant Prodigue. But they lined with the F-s Friday and are, I suppose, completely launched by now. The $\mathrm{D} \longrightarrow \mathrm{s}, \mathrm{A}-\mathrm{J}-$ 's people, have also invited them, and when the start is made, they will run their course. They don't seem to care so much about it as the L-s. They are perfectly acharnées over it.

It is a dull, drippy morning, and I suppose we shall pass the day in the house. It is now halfpast nine and we do not breakfast till ten. The nearest church is two miles away, too far for me to walk, and there seems no preparation for driving.

Breakfast is over. We all assembled in the hall, and after considerable waiting, breakfast was announced. We went in-a great plenty and variety-but no host or hostess. Breakfast was half over when they came in, blushing and ex- 
cusing themselves. They had "slept in." Cnever goes to bed before two o'clock.

There is to be another rendezvous in the Hall to look at the orchids at half-past eleven. So I will finish this and post it.

Young $\mathrm{H}$ — tells me that Lady $\mathrm{H}$ sent me a note yesterday asking me to lunch to-morrow. So I think I will go in by the 9.30 train and so arrive there by the lunch hour. It is only the difference between lunching here and there.

HAY TO ADAMS.

London, June 9, 1894.

.... Next, let me congratulate you on your L_ prize. It is good money, and the old Duke will be delighted that it has gone into hands so worthy. Don't spend it till I get home, and we will paint the horizon crimson with it. The only wonder is that $\mathrm{C}$ - College could have done so evidently sensible a thing.

We spent a pleasant day at Cambridge yesterday .... and got home in time to make ourselves beautiful for the Court Ball at Buckingham 
Palace. You ought to have seen me! My wife and $\mathrm{H}$ - looked rather handsome, but the old man! Great Scott! je ne vous dis que ca! . . . . M- swore that he would have me kodaked in my clothes, so that I would never dare to run for President-from which it was easy to see what was preying on his mind.

.... We dined at Mrs. D-_'s the other night. Lord $\mathrm{H}-$ was there, taking a brief vacation from his troublesome boycottery, looking young and handsome and gay. Also the new genius, $\mathrm{J}-\mathrm{O}-\mathrm{H}-$, a pretty, elever and joyous St. Louis girl, with a scapegrace husband in the offing somewhere; and a few others. Mrs. $\mathrm{D}$ - has settled in your old neighborhood, Queen Anne's Gate, 28, a very airy, bright house, of which she has taken a long lease, and where, God willing, she proposes to live and die. Miss F-_-Miss Val, I mean,- - has written a new novel, to be printed next week. Everybody is in the straw with a new book. Don't you forget, by the way, to save me a copy of your Tahitian family history. S- is kicking up a bobbery about Samoan affairs,- - out of which your friends $\mathrm{G}-$ and $\mathrm{G}-\mathrm{I}$, see, propose to scuttle. You may thank your stars you were not in Lon- 
don when Ladas won the Derby. They ate, drank and dreamed nothing else for twenty-four hours. They are a dear and simple folk, in some waysthese English.

\section{HAY TO ADAMS.}

\section{London, June 19, 1894.}

MY ONLIEST :

I got yours of the 8th last night at midnight, as I returned from the dinner of the Fishmongers, stuffed with turtle and spiced meats, drenched in loving-cup and B-'s eloquence. How our Ambassador does go it when he gets a big roomful of bovine Britons in front of him! He knocks them all silly. I never so clearly appreciated the power of the unhesitating orotundity of the Yankee speech, as in listening-after an hour or two of hum-ha of tongue-tied British men,- to the long wash of our Ambassador's sonority.

.... I doubt if you ever see this letter, and therefore I will not inclose the balance of your account against me. You will be at $\mathrm{D}-$ Castle, or on the roof of the world, or in the 
shadow of the Taj, I suppose, next Fourth of July, when I shall be wrestling with the fiends of the Custom House, and deliquescing in the effort to get to $\mathrm{C}-$. Send a little line to the $\mathrm{K}-$ Club to meet me and bid me welcome to your effete continent.

The world is going to be too many for me. I have an engagement for every blessed minute until we sail, and I shall welcome the malady of the sea as a blessed relief from my "dear dam distracting town." Why am I not five-and-twenty?....

HAY TO ADAMS.

Cleveland, O., July 12, 1894.

DEAR ADAMS:

After a week of struggle against fate I have succumbed. Even indolence gives way to a stronger God, and Mrs. $\mathrm{H}-$ has convinced me that it is best for $\mathrm{D}$ - that I take up my pilgerstab again and go to the Yellowstone. I have not the heart to ask you to write me a letter par une chaleur pareille-but toddle down to the caligraph and dictate to one of the young ladies 
there a word of counsel. Tell me once more when and where I am to meet you. I done forget whether it was Chicago or St. Paul-and the day -and the tavern.

If railroads run, I suppose you prefer them. But if $\mathrm{D}-$ is still obstreperous, $\mathrm{S}-\mathrm{M}$ suggests a Lake Boat. . . . .

I have a little note from $\mathrm{K}-$, dated the 30th June, from Green River, Wyoming, en route to Colville, Stevens County, Washington. He tells me nothing, of course. I think he must have joined some oath-bound order which pledged him, under fearful sanctions, never to tell anybody anything.

We went to a big wedding last night-I never saw so many pretty women in my life-and never found it hotter. But I am old and frileux. I like it hot.

After all, I look forward with something like pleasure to the prospect of passing a month with you. 
HAY TO ADAMS.

Cleveland, O., July 14, 1894.

DEAR ADAMS:

On receipt of your telegram I engaged a berth on the Wednesday night 6.50 train from Cleveland to arrive in Chicago on the morning of Thursday, 19th. We will await you at the $\mathrm{G}-\mathrm{P}-$ Hotel, unless you indicate some other hostelry.

Your letter of yesterday has this moment arrived. I will try to do the things that Bordains, but would fain leave some of them to be done further west. The bed business for example. I cannot lug my bed across a continent. Certainly there must be a place nearer the geysers where a bed can be procured by the unstinted use of money.

And the guns! B-, who is a hardened sportsman, says there is not a bird west of St. Louis; that a shot-gun will be of no use except for purposes of suicide. I mentioned a rifle, and he said it would be of use, to shoot at a mark.

Fishing tackle! D - never cast a fly in his life, and I could as soon think of dancing a serpentine.

I have bought four rubber blankets, but they are only half the size you specified. They are 
4x6. Perhaps I can sew two of them together. There were none of the larger size.

Altogether, I expect to arrive in Chicago with not an accursed thing of all I ought to have. When do we pull out from there? Will there be time there, or in St. Paul, to supply the needed outfit? Would it not be as well to take a bag of money and get the things after I strike you and the intelligent $\mathrm{B}-$ ?

\section{HAY TO $\mathrm{C}-\mathrm{S}-\mathrm{H}-$}

St. Paul, Minn., July 20, 1894.

We got away from Chicago last night. The heat was something frightful, but it let up a little as soon as we left the city. A shower of rain came on. We were delayed an hour or two by a "traction engine" which had strayed across the track and stopped. D-went out to investigate and coming back, told me that he and two gamblers had assisted in getting the obstruction off the track. It grew gradually cooler and when we came to the Mississippi it was quite bearable. In spite of our delay we got here on time and met $\mathrm{A}-\mathrm{P}-$ and $\mathrm{I}-$ in the station. $\mathrm{A}-$ 
at once retired, had his bath and came out immaculate in white flannels with a white peaked cap; he looked awfully like Lord Randy. After breakfast $\mathrm{P}$ - went out to buy tickets and things. $\mathrm{D}$ and I went out to buy ammunition and soap. Then A- and I went for a drive to see the town. A- has written to $\mathrm{K}-$, begging him to come down and join us on his way back from Washington State. I do not expect him, but perhaps he may come. I- and $\mathrm{P}$ - have bought us bedding, etc.

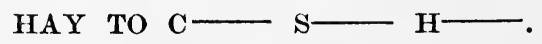

Livingston, South Dakota.

Sunday, July 22, 1894.

We arrived here all well and on time this morning at 4.10. We found the station heavily guarded by two companies of U. S. soldiers, one black and one white. We found we could get no breakfast till 7.30, so we went out for a walk. We saw the sun rise over the Yellowstone River, and then $\mathrm{D} \longrightarrow$ and $\mathrm{I}$ accompanied $\mathrm{A} \longrightarrow$ and I- on a geological walk up a hill near the town from which we had a magnificent view and where 
I picked these flowers. Then we came back to the Hotel and still breakfast is not ready and I can scribble you a line. We leave for Mammoth Hot Springs at 8.45 this morning. I feel as if I had been here about a week.

$$
\begin{aligned}
& \text { HAY то } \mathrm{C}-\mathrm{s}-\mathrm{H}- \\
& \text { Yellowstone Park, Wyoming, } \\
& \text { July 23, } 1894 .
\end{aligned}
$$

We start to-morrow morning on our trip through the Park, and I cannot tell when I shall get any letters or when I shall send any. I will write frequently and send them when I can. You can write to me here, and $\mathrm{McD}$ - will send them when he gets a chance. We went for a long drive to-day to a ranch in the mountains where there was a bear, which was caught the other day, in an iron cage. He was a big and ferocious fellow who simply could not make up his mind to be reconciled to his fate. He had eaten a whole hog since he was captured. In fact it was his fondness for pork that led to his ruin, as he had stolen two hogs before the ranchman made up his mind to 
catch him. They have telegraphed to L-, so perhaps we may see him again in W-I I picked these gentians at the foot of the Gallatin Mountain. I am afraid they will lose all their beauty en route, but they were pretty this morning. We have not yet found any cool weather. This place is very warm and there is a cruel glare in the light. But every one tells us that we must have plenty of warm things for camp. A-_, in his white flannels and wide-brimned sombrero, looks very cool and Cuban.

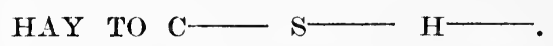

\section{Grand Cañon Hotel, Thursday, July 26, 1894 . No. 1.}

I do not know that I ever saw a day so stuffed full of natural beauty and grandeur as yesterday. We started early and went to that part of the Grand Cañon which is called by the idiotic name of "Inspiration Point," a name by which the finest view at Yosemite and other places is disfigured. It is a rock which juts out over the Cañon and gives a wonderful sweep of view both 
ways. A strong wind came up while we were there and we had to hold on by our teeth and toes to keep from blowing away. Before we left, a lot of lady tourists came and they had to be held on by the guides. Even two hats went sailing gracefully down into the chasm a thousand feet below. All around were those brilliant-colored crags and walls you see in Moran's picture in the Capitol. Half way down we saw an eagle's nest with two great eagles sitting quietly at home with their family. After we had stayed there some time we walked slowly up towards the Falls, stopping at every favorable point of view; the scene changed every moment, giving new aspects of beauty and magnificence. When at last we got to Lookout Point, the full glory of the Falls burst upon us. They are just twice as high as Niagara and the "setting" of them is immensely bigger and grander. You cannot imagine anything grander than the red, yellow and green rocks of the vast cañon and the quiet background of the green-wooded mountains. In the afternoon I stayed at home and D- and $\mathrm{B}-\mathrm{P}-$ went ofi for trout. $\mathrm{D}$ - went as a spectator and pupil. They came back in a few hours. I heard the family whistle under my window and looking out saw $\mathrm{D}$ - carrying a $20^{2}$ 
splendid load of big trout, some speckled and some rainbow! which reappeared a little while after on the dinner table.

We have not come to the "roughing it" as yet. I do not know how long it is delayed. The Hotels so far are excellent-but in the depth of woe on account of there being nobody in the Park. Last year the panic, this year $\mathrm{D}-$; there is no end to their troubles.

\section{HAY TO $\mathrm{C}-\mathrm{S}-\mathrm{H}-$ \\ Yellowstone Park Hotel, July 26, 1894. No. 2.}

I do not know when you will get this or in what condition these flowers will be when they arrive. But they are so sweet and fragrant that I must send you one or two. The white one is phlox and the pink are yarrow.

This is another wonderfully beautiful place. The great Yellowstone Lake lies just in front of us, and beyond it is a chain of magnificent mountains. We left the Grand Cañon after lunch to-day. Just as we were leaving an unmistake- 
able English couple arrived, a gawky, aristocraticlooking man in knickerbockers and a young woman, blond as wheat and awfully sunburned, the English "Mees" of French farce. The proprietor of the Hotel ran after us to say it was Mr. and Mrs. R-W- The drive here was delightful; about three hours. Our road ran beside the Yellowstone River all the way, a clear, tranquil stream, which gave no hint of the terror and magnificence of the fate that awaited it a little farther on. In one place we saw dozens of enormous trout playing near the bank. In another a big flock of wild geese were walking along. They calmly stepped into the water and swam away as we came up. Half way here we came to the most hideous and dreadful sight I ever saw, the Mud Volcano. We heard it grumbling and coughing before we got there, but when we approached it, no words can describe the horror and fascination of the sight. To think that for ages and ages that hideous throat is expectorating that red sea of mud every other second.

This Hotel is very comfortable, as are all the hotels in the Park. There are about twenty people here instead of two hundred as there ought 
to be. The first names on the register this year are Mr. and Mrs. $\mathrm{R}-\mathrm{D} \longrightarrow$.

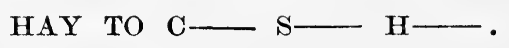

In Camp, Upper Geyser Basin, Saturday, July 28, 1894.

We arrived five minutes ago in this beautiful place and found $\mathrm{H} \longrightarrow$ in camp-our tents all up and the horses picketed on the banks of the Madison fork. "Old Faithful" is in sight from our camp and will spout in a few minutes. I fear this is the last chance I shall have of writing to you for a good while. I may write you one more from Fountain, but that will be the last for several weeks. H- gave me just now your letter of the 21st and one from L- A- A- Ahas one from $\mathrm{K} \longrightarrow$, he has been delayed badly by the strike and so cannot come to join us.

The driver, who has been with us all through our trip, will take this to post at Hot Springs. We had a glorious day yesterday, full of adventure, which I will tell you all about the next time I write. 


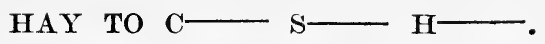

In Camp, Upper Geyser Basin, July 29, 1894.

In writing my hurried note last night I promised to tell you what we had seen the day before, and as this is Sunday and a leisure day I will write you about it now. I am sorry I cannot write in ink, but there is none in camp and my fountain pen will not work.

We left the Hotel at Yellowstone Lake in the morning in the little steamer Zillah, which put us ashore and promised to call for us in the evening. We pushed up on the hill and got a beautiful view of the Lake and the mountains. It was a wild and lovely place, where tourists never go and where few white men have been. There were park-like stretches of grass and clumps of trees that looked like the Fells. I- $\longrightarrow$, who was a little in advance of $\mathrm{A}-$ and me, suddenly stopped and motioned for us to keep still. We crept up to where he was and saw a beautiful sight. Several great elk stood in the edge of the wood a little way off, and several others lay in the grass. We stood there a little while enjoying the sight and 
wishing $\mathrm{D}-$ and $\mathrm{P}-$, who had wandered away from us, could see it also. But I soon caught sight of them at the top of a hill near by, crawling on all fours through the sage brush to a place where they had a still better view. I joined them there and we lay in the sweet-smelling shrubs watching those beautiful creatures, feeding, walking about, getting up and lying down. There were eleven in all. Shooting in the Park is prohibited and besides this is not the season for killing elk, so we enjoyed watching them with no idea of murder in our minds.

We walked for an hour through those untrodden woods and came upon a mud volcano. You can have no idea of the hideous ugliness and strangeness of these objects. They are not only repulsive to look at, but the noises they make sound as if the very mountains were sick.

We went down to the shore where we had cooked our lunch, and after waiting awhile for $\mathrm{A} \longrightarrow$ and I-, we fell to and lunched with a good appetite. Then $\mathrm{P} \longrightarrow$, and afterwards $\mathrm{I}-$ made ready their tackle and began fishing. I knew they would have good sport, for I could see the big trout swimming by the rocks in dozens. They caught them as fast as they could throw 
their flies. D__ took a line and did very well for a beginner. By this time the steamer appeared in the distance and we had to launch our little boat to get on board. But there was a high wind blowing and as often as we would shove her off she would fill with water. $\mathrm{D}-, \mathrm{P}-$ and A - got wet through, and I- and I not much better. The first three sent their clothes to the engine room to dry and lolled on the cushions in the cabin in more or less elegant deshabille. I let my things dry on me till I got to the Hotel and then went to bed and sent them to the kitchen. You might think this was adventure enough for one day but more was to come. We had heard of bear that frequented the woods behind the Hotel, and $\mathrm{D}$ - and $\mathrm{P}$ - went out to look for one. It was after dinner, but the sun had not set. After watching awhile they saw a bear come out of the woods and begin to feed. In a few minutes there came another, and shortly after a big grizzly came loping down the hill directly towards them. Something scared him and he galloped away into the brush. At this time I went out to see what had become of them. By sounding the family whistle once or twice I found them on the edge of a little open space in the 
pines. They told me what they had seen, being of course in high excitement. I stood with them a few minutes. The light was fading and I thought the fun was over, when there glided into the opening a black bear who trotted right before our eyes to the feeding place. He was very cunning, seemed very much at home until he was alarmed at hearing a wagon and ran away. He had hardly gone when an enormous grizzly came tearing through the brush, making as much noise as an elephant. It was wonderful when he came in sight to see how lightly and gracefully the big creature moved. He stayed quite a while, giving us an excellent view and at last caught sight of us. He turned and stared us in the face. We did not stir; but he evidently was not desirous of making our personal acquaintance as he turned and ran away. We went into the Hotel and counting up the bears we had seen I said it was a pity we could not have seen another to make it a round half dozen. At this our driver came in and told us that a bear had just got into a wagon near the Hotel and was tearing things to pieces when the dogs got after him and chased him into a tree. We all rushed out and there was a great black bear, clinging about half way up a pine tree. A 
lot of people were throwing sticks and stones at him and indulging in a good deal of talk more or less cheap. At last our driver, who had not said a word, began climbing a tree which grew close by the one the bear was on, only a foot or so distant. Arriving at the height where the bear sat he broke off a limb and began beating the bear, who growled and bit and scratched at him, but began slowly backing down the tree. The people below began to throw things at him, but the driver said: "Don't hit him, boys, or he'll come back and use me up." So they waited till he was down and everybody fired a parting volley as he galloped away. It is the most extraordinary bear story I have ever heard. Six bears in one evening and not a gun in the party. Shooting is strictly forbidden, which makes all animals very tame. I- came across a rabbit this morning, which let him come near enough to touch him. I forgot to say we saw on that same day nearly a hundred pelicans, the biggest gentian I ever saw and a mountain rosebud. 
HAY TO $\mathrm{C}-\mathrm{S}-\mathrm{H} \longrightarrow$.

In Camp on Wolverine Creek, Wyoming,

August 5, 1894.

This is a beautiful, warm Sunday and as there is no travel and no shooting and no fishing, at least in our branch of the party, I take up my record of our adventure where I left off, though I have only the slightest hope of ever being able to send you these lines, in spite of the optimistic $\mathrm{H}$ — who still says cheerily "we shall meet somebody going in." Our first two days' travel, Tuesday 31st and August 1st, led us over the famous Sheridan trail which the General had named for President Arthur when he visited the Yellowstone. It was pretty rough in places, but the scenery was beautiful. We rode in a notch of a great hill overlooking the Shoshone Lake, where we could see the stones at the bottom and where a slip of our horses would have given us a tumble of one hundred and fifty feet. It was the place where $\mathrm{A}-\mathrm{H}-$ lost some of his pack mules years ago. We lost nothing, although two of our pack horses fell, recovering themselves before reaching the water. August 1st we had a very 
difficult path through the woods. $\mathrm{B}-\mathrm{H}-$ went ahead with an ax, and we could hear his ringing blows soon followed by the crash of a tree and his cheery "all right." I was with him the earlier part of the day. We came at last to a little stream. He said, "Here is where Theodore Roosevelt's horse backed him off." We camped there in a cloud of mosquitoes which beat anything I ever saw in my life. We had provided ourselves with shields which covered the head and neck like a canary cage-but nothing availedthey crept under gloves, collars and hats. This continued for two whole days and nights and nearly drove us frantic. But there came a cold night and a blessed relief, and we have had hardly any trouble with them since. It was a delightful feeling to wake up in the night half frozen and to miss the maddening hum of those pests.

No matter how early we might get up and determine to start, we never could get off before 8.30. The breakfast, the catching and saddling the horses, took up all the time from 5.30 when the man began to stir. We got away at last, the first hour or so of our ride through the dim dewy woods was perfectly delicious. Our party, guided by $\mathrm{I} \longrightarrow \mathrm{s}$, set out two or three hours 
before $\mathrm{H}-$ and the pack. We would rest ourselves. $\mathrm{I} \longrightarrow \mathrm{S}$ and $\mathrm{P} \longrightarrow \mathrm{S}$ would fish, and we would have our frugal bread and butter, seasoned with a sardine or a bit of chocolate-then the pack would overtake us and we would go on together to camp. There are absolutely no roads through all this country. After the first two days there was no regular trail. Part of the day we would follow the trails made by the elk through the woods, and the rest we would push through with no guide but the sun and the compass. August 2 we came to Heart Lake, which is exactly like B-'s picture in the Corcoran Gallery. It is a lovely sheet of water covered with pelicans, wild geese and ducks. We halted by a little torrent for lunch in the midst of a garden so wonderfully brilliant and splendid that it was hard to realize it had planted itself and blossomed in the wilderness from time immemorial. The field was one blaze of painted cup lupins, wild parsnip, bachelor's button, yellow marigold, wild geraniums and others I did not know. Then the pack came and we joined in a scramble through a trackless forest ending in a most beautiful view of the wide valley where the Snake and Heart Rivers join. We descended 
an almost perpendicular hill, leading our horses zigzag. Friday, August 3, we rode through the beautiful valley of the Snake River. At noon we mounted a great hill where we lunched. We had no water, but the view made amends. At last we heard the bells of our train on the other side of the valley and soon saw them winding along in the distance far below us. They made a fine appearance. We joined them at Coulter's Creek and $\mathrm{A}$ - said he would not ride with the pack. I stayed with him for awhile, but our horses did not like it and made such a row that I thought we might as well ride on. $\mathrm{He}$ was obstinate and refused, but his horse cut up so that he had to dismount and tie him to a tree. I saw no fun in that, so $I$ rode on and joined the pack, while $\mathrm{P}-\mathrm{S}$ and $\mathrm{I}-\mathrm{s}$ went back to keep $\mathrm{A}-\mathrm{s}$ company. It was an awful trail, and $D-$ and $I$ had to help. It was a curious experience, I only wonder that a train ever gets through. It seems to be going to pieces every minute. The men half frantic, the horses laying down in streams, packs slipping off, canvass tearing on the bushes, the different sections of the train getting separated in the pathless woods, all form a scene of exasperating confusion. There is 
one horse in the train who is a source of endless arnusement, his name is Grover Cleveland. He is white, but he has worn a red blanket badly dyed, and the rain has stained his back and sides with a brilliant red. $\mathrm{He}$ is always in trouble and it sounds awfully comic to hear the men say: "That Iron Clad is always trying to get ahead of the pack," "That G. C. was so mighty smart he wouldn't cross the trail but walked into a quicksand," or "Two or three horses have followed Grover Cleveland into the bog."

Yesterday, Saturday, 4th, as we had a full day, we started at 8.30 as usual to take a ride up Mt. Hancock and as we were out of meat $\mathrm{I}-\mathrm{s}$ and $\mathrm{D}$ - took their rifles along on the chance of seeing an elk. I should have liked to have a shot myself, but I thought he would enjoy it more than I. We saw one fine elk by the mountain side, but he was not accessible. We rode on over a rough trail and suddenly found ourselves among hundreds of fresh elk tracks, showing that a great herd had just passed, and a moment after we saw about a mile distant the biggest band any of them had ever seen. There were certainly not less than 300 elk quietly feeding along the slope of the hill. $\mathrm{I} \longrightarrow \mathrm{s}$ and $\mathrm{D} \longrightarrow$ started to make a long detour 
to get a shot. We waited belind with the horses about an hour and at last saw the whole herd move rapidly away and disappear in a depression of the hillside. We thought they had taken fright at the approach of the hunters and mounted and rode to find them. But when we had got to the place where the elks had been feeding we heard the crack of a rifle and then another and a fine elk moving away as if wounded. We came up to them but they were too keen after their elk to take their horses. They ran after him on foot and we followed about hopelessly for two hours on our horses, leading theirs trying to get in sight or trail of them. D-looked awfully tired when I last caught sight of him toiling up a mountain side, and I was very anxious for fear he would injure himself keeping up with $\mathrm{I} \longrightarrow \mathrm{s}$, who is as lean and active as a stag. To add to my trouble a thunder storm came up while we were on the very top of the ridge. We could hear or see nothing of them. After waiting awhile we went slowly down the crest of the ridge calling out once in awhile. At last we heard another shot and following the sound we came upon the hunters and elk - and who were tired to death and very happy. It was then three o'clock and they 
had chased the elk since eleven as hard as they could tear, up hills and down ravines. I think I will not give you a particular account of the subsequent proceedings. It is enough to say that the butcher's business is a necessary part of the equipment of a mountaineer. An elk is too big to carry home. It must be dissected on the spot where it falls. I—s, assisted by $\mathrm{D} \longrightarrow$ and $\mathrm{P} \longrightarrow \mathrm{s}$, was two hours in cutting up the animal. They tied up some of the nicest parts in a waterproof overcoat and hung up the rest in a tree to keep it from the bears. We then started for camp. The view we got of the Teton Mountains was one of the most beautiful and majestic I have ever seen. It is as grand as the grandest in Switzerland. We had another scramble down the side of the mountain. Our horses are wonderfully surefooted. They can walk where a man could not. We came upon another great herd of elk in the thick woods half way down the hill. But it is not considered sportsman-like to shoot elk except when you want meat. We saw also in the road an enormous old porcupine, who waddled away in the most ungainly manner. When we got into camp we found that $\mathrm{H} \longrightarrow$ had also shot an elk, so that we have all the fresh meat we want for the 
present. I enclose some forget-me-nots from the summit of Mt. Hancock. The ground is blue with them.

HAY TO $\mathrm{C}-\mathrm{S}-\mathrm{H} \longrightarrow$.

In Camp on Snake River, August 10, 1894.

To begin where I left off! A-s was so ill with a swelled face Sunday and Monday, 5th and 6 th, that we could do nothing but lie about camp and wait for him to get better. D- and I went out for a walk in the afternoon and we shot three mountain grouse, which we had for dinner and which were very nice. They are white and tender, not at all like prairie chickens. The next day we started for Pacific Creek, as A- was decidedly better. We had a pleasant ride of five or six hours over a very rough trail. At noon we stopped for lunch beside a little lake and began fishing for trout. I never saw them so plentiful. $\mathrm{D}$ — took a stick and tied a hook and leader to it and caught several big ones, while $\mathrm{P}-$ and $\mathrm{I}$ - were drawing them in in their scientific $21^{2}$ 
fashion. In the evening we came out on a beautiful place to camp, with a grand view of the Teton Mountains. We were astonished to find an Indian tepee beside the bank of the brook, and thought at first we had struck a camp of Aborigines, but it turned out to be a "Philadelphy party," the $\mathrm{P}-\mathrm{S}$ and $\mathrm{W}-\mathrm{S}$. I did not visit them, but $\mathrm{P}-$ and $\mathrm{D} \longrightarrow$ did. Mrs. $\mathrm{P}$ - was a $\mathrm{D}-$ and a Vassar graduate, and Mrs. W_ was reported to be a pretty woman in bloomers. The show of the mountains all on fire with the sunset light was one of the most beautiful I have ever seen, and I would grow monotonous if I went on to tell you how marvellously fine every changing aspect of these glorious peaks has been ever since we first came in sight of them. They are nearly as tall as Mt. Blanc, and to my mind more interesting. Wednesday, 8th, in the morning it threatened rain and we concluded to be on the safe side and take it easy. So H__ and I- hung around camp, and I read Brossier's life of Cicero and $\mathrm{D}-$ went with $\mathrm{H}-$ to blaze the route. In the evening the sunset view of the mountains was so magical that we all ran half a mile to the river bank to get an unobstructed view of the whole range. Thursday morning gave us an 
absolutely cloudless sky and off we started to Buffalo Creek and Snake River. We had a long ride, the route being unknown to any of us and there being no distinct trails. We rode through the woods, over meadows which were ablaze with flowers, by cottonwood bottoms through a country which seemed more like Missouri than the Rocky Mountains and at last came, to our amazement, upon a rude wagon road. Crusoe was hardly more astonished by the print of a human foot in the sand. We followed the track and came upon the junction of the Snake and Pacific Creeks, and a little while after came to Buffalo Creek, a swift and strong torrent, which we forded. It was a lovely country and we saw several antelope who made a pretty addition to the landscape. We found a good camping place beside the Snake River and just then we heard the bells of the pack train. $\mathrm{H}$ - had made good time and had arrived on our very heels. This morning we concluded to stay here a day or two. D- is going to ride with one of the men to the only ranch in this region. I got some condensed milk and I am hurrying this note to seize a possible chance of sending to a post office. We shall be at Mammoth Hot Springs again in about a fortnight and shall then know 
where you are and how the world has gone on since we left it.

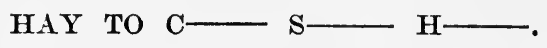

Camp on Buffalo Fork,

August 12, 1894.

The letter I wrote you Friday in such a hurry was not destined to be sent at present. Just as $\mathrm{D} \longrightarrow$ was mounting his horse to ride over to Sargent's Ranch, a queer team with two queerer men were seen meandering over the plain. Hran out to speak to them, the advent of a stranger being an event in this neighborhood. He brought them both into Camp-the perfect ideal of the tramp of the mountains. They called themselves "plainsmen," they are trappers and hunters, carpenters if you pleased, the loafers of the frontier, with a certain elegance of speech that contrasted oddly with their looks and dress. They told us that there were no supplies at Sargent's, so D- had to give up his trip. But he and Charlie went off hunting instead and he was again disappointed. They saw no game whatever, except at evening 
coming home. D- saw some grouse so near the dining table that we had to scatter away to let him shoot them. The rest of us spent the day on a great Butte which gave us a very fine view of the Teton range. We passed by the place where $\mathrm{R}-\mathrm{R}-\mathrm{H}-$ was drowned. We saw several bands of antelope, the most beautiful, graceful creatures you can imagine. We were not near enough to murder them. Yesterday B$\mathrm{H}-$ and I went off for a day of trout fishing. I found it easier than I imagined to cast a fly and got a nice little string of fish.

This has been a quiet day. We are encamped on the very edge of a swift torrent. Our dining table is only a few feet from the steep bluff. Our amphitheatre of great hills is all about us, and in the far South the glorious chain of the Tetons is wrapped in the light of dying day growing more beautiful as we recede from it. We are living altogether too well. We had to-night, for instance, a good soup, trout broiled, elk with curry, peas, beans, boiled rice, and, to wind up, an excellent plum pudding. We have a bountiful breakfast, then we spread a slice of bread and butter for lunch, which we carry in our pockets and eat beside some icy rivulet. I fear the effects of all 
this on our waists. I had hoped that six hours daily on horseback would reduce me to sylph-like proportions. I am in good spirits to-day because our faces are set towards home. We made our furtherest march South and West yesterday.

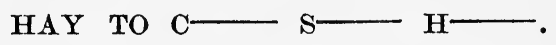

Camp on Soda Creek, August 15, 1894.

$\mathrm{H} \longrightarrow$ and $\mathrm{I} \longrightarrow \mathrm{s}$ have gone ahead to look out a trail for to-morrow, as we are now in a country so utterly wild and unknown that there are no maps of it on which any reliance can be placed. $\mathrm{P} \longrightarrow \mathrm{s}$ is fishing as usual. $\mathrm{A}-$ is packing and repacking his bags in his tent, where there is a temperature of $100^{\circ}$. D- and Charlie B- have gone up the mountain to try for an elk, as we are almost out of meat. It is terribly hard work hunting in these mountains. We know there are hundreds of deer and elk in this region, yet the best hunters spend weeks of incessant labor from dawn till night without ever getting a shot. We left our glorious Tetons 
several days ago and pushed eastward up the Buffalo River. We had an awful scare last Sunday night after we had gone to bed. I- saw a light in the woods and he and $\mathrm{D}$ - went out to investigate it. It turned out to be a fire, probably started by somebody dropping a match. I__ came running into camp hoarse with excitement, shouting the news and collecting all the buckets we could muster and started everybody for the scene. It looked very serious for a while; if it had had a few minutes more start there would have been a forest fire which would have raged for weeks, destroyed our camp and horses and made it very unpleasant for us. But by pulling the burning logs apart, stamping out the flames, shovelling dirt and bringing waterwe got it under control before midnight.

Monday, the 13th, we had quite an exciting day of it. We started as usual ahead of the pack and stopped at noon to wait for them. We discovered them and watched their progress up hill and down dale for half an hour, and at last being certain of their direction we clambered down the hill to meet them. When we got to the bottom they had disappeared as though the earth had swallowed them. We waited a long while and 
then started on to what I-s thought was the rendezvous. But in this region, where nothing is properly mapped or named, he and $\mathrm{H}-$ had not understood each other, and so we wandered about for four long and anxious hours, looking in mountain and valley for our lost train. We had about concluded we would have to sleep under the frosty sky without any supper, and we cast hungry glances at an aged porcupine who hustled out of our path as if doubtful of our intentions. At last we did what we ought to have done at first-went back to the place where we had last seen them and found their trail which led in an exactly contrary direction to that where we had been looking for them. Our horses evidently smelled their friends, for they set up a joyful whining and jaded as they were began trotting gaily up the valley. We found them all in camp in a green valley through which runs a brawling stream fringed with willows. It is closed at the eastern end by a great rock which looks in some lights like the Sphinx and in others like a couchant lion. Green mountains, bare at the summit, stand on both sides. The moon is now full and nothing can exceed the beauty of our moonrises. Over the dark summit of the moun- 
tain at the South a great shaft of light darts up and hangs a moment, as if to announce the coming of the moon, which soon follows almost as brilliant as the sun. You can hardly gaze at it without being dazzled. Last night $\mathrm{D}$ discovered in it the face of a woman. It was perfectly evident to all of us, a dark, Spanish face.

Just above our Camp is a wonderful spring of soda water. It is strongly tinctured with iron and full of gas. It is deliciously cold and refreshing. If we had it in reach of railroads we would make the valley famous as a health resort. I had written this far when $\mathrm{P}-\mathrm{s}$ called my attention to a dark object, half a mile up the valley, which he thought was a bear. I grabbed a gun and we ran towards it. It turned out to be a black pack horse which had gotten away from I-s and $\mathrm{H}-$, so that they, poor fellows, will have to pack his load on their horses and walk home.

$\mathrm{D}$ —_ and Charlie have just come into camp after a long day in the mountains with their usual bad luck. They did not see an elk or a deer. None of the hunters got anything to-day; neither bird nor beast.

P. S.-HThey killed a grizzly bear. 


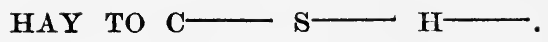

Camp on Headwaters of Yellowstone River, Sunday, August 19, 1894.

This is one of the most beautiful camps we have yet inhabited. I must go back and tell you how we came here. I last wrote on the 15 th. The next day we broke camp and moved for the headwaters of the little stream we called Soda Creek. It was a fine ride through a pretty valley walled in by great mountains of $\mathrm{B}-$. The head of the creek was wonderfully beautiful. Imagine a fountain twice as big as that of Trevi, gushing out of the solid rock and fifty feet above ground. We camped by a fine lake of robin's egg blue color. I-s spent the afternoon working on the skin of his grizzly. It is a dirty and laborious job. I would never want one if I had to cure it myself. The next day (17th) we had another beautiful and interesting ride over the mountains. We saw Buffalo Lake and Falls and then ate our lunch on the brink of the vast chasm of the higher Yellowstone Cañon! We had an uncomfortable camp-but made the ascent of a mountain near it from which 
we had a marvelous view of a world of peaks. Gros Ventre, Tetons, the Jug, Panamora and the Yellowstone Mountains were all spread out before us like a map. We resolved to stay there only one night and yesterday we made an early start, getting away from camp at 8.10. We had seen enough to convince us that there was no outlet from the valley of the Buffalo unless we retrace our steps, which would be rather ignoble, or else cross the great Continental Divide and get into the valley of the Yellowstone, which would lead us home via the Park. There was no trail and so far as we knew no one had ever done it. We started early and went up the steep ascent among the loose stones. We had to lead our horses, and we "puffed like a paragraph praising a pill." We got at last to the ridge and saw it stretching out interminably in front. But we pushed on over the backbone of the Continental, I-s' long legs leading the march, till we came to the north end of the ridge and saw that though the descent into the Cañon was awfully steep it was not impossible. The view was magnificent. We could see, only a few feet apart, the springs that furnished the Snake, which runs into the Panamora, which 
runs into the Gulf of Mexico, and all round a tumbled world of great mountains. We got off our horses again and began our scramble down the mountain side, slipping in the ashy dust, sinking in boggy grass; sliding and slipping over great fields of snow, we at last got to the bottom. It was an hour or two before the pack train arrived-the first that had ever made the passage over this mountain-and then we moved along the valley to this camp. It is a very pretty place; on either side the great cañon walls rise a thousand feet into the air. In the centre of the wide valley, the torrent-a very young and small torrent-only a few hours old, brawls along. The valley is full of flowers. At short intervals fountains of ice cold water gush from the gray rocks. Just above our camp about one hundred feet from the top of the cliff, a crystal stream leaps out of the crag and runs leaping and dancing to the river. I climbed up to it yesterday and found a big porcupine loafing near a rock beside the fountain. I told D- and he scrambled up there and teased the poor beast till he dropped a lot of his quills, which $\mathrm{D}$ - appropriated. We saw, coming to the Divide, seven mountain sheep, the rarest creatures in the mountains. Poor 
$\mathrm{D}-\mathrm{had}$ an excellent shot at them, but at the instant he was about to pull his trigger, Iappeared just beyond them and $\mathrm{D} \longrightarrow$ lost the greatest chance of his life. The camp is still and almost deserted. Billy $\mathrm{H}-$ has gone ahead to look at the trail for to-morrow's march. I-s has gone up the mountain to try to shoot a sheep. $\mathrm{P}$ - has gone fishing; $\mathrm{A}-$ has taken his sketching things up the Cañon; D- and I are left alone to keep Sunday and the camp. I found a beautiful piece of petrified wood which I will try to bring home for a paper weight. A- gave Billy his orders to-day that there must be no more stops. "I am bored," he said in his most royal tone. As this is the 19 th and it will take us a week to get to Mammoth Hot Springs, I am now hoping to pull out for Livingston in about ten days.

\author{
HAY TO ADAMS.
}

Newbury, N. H., Sept. 9, 1894.

MY DEAR ADAMS :

I have thought of you often since we left you on the platform at Livingston to pursue your lonely 
way westward. I hated to leave you, but I felt you would be relieved at being alone for a while. You had my heartfelt sympathy.

I made very quick work of my journey hither. I intended to stop a day in $\mathrm{C}-$ - but discovering that a train for this point started in an hour and a half after my arrival there, I flew to my office, gave an hour to business, and-tant bien que mal - got through, and jumped on my train, to D__'s delight, who is at the age to appreciate such helter-skelter work. I got here a day ahead of schedule time, surprising my wife and family in a very satisfactory manner. I found all well, and immediately proved the superiority of Rocky Mountain to White Mountain air by going to bed with a vile, body-and-soul-pervading coldacquired, I imagine, in sleeping-cars.

$\mathrm{I}$ have a letter from $\mathrm{K}$ - from Spokane, of August 30, from which I infer that his business up there is finished, and that he was going to Denver via Salt Lake to meet Mr. H- about the $3 \mathrm{~d}$ September, and thence to New York. If you inquire at the $\mathrm{C}-$, you can ascertain if he is in town. He seems rather low in his mind, but looks forward to you and the Windward Islands. 
HAY TO WHITELAW REID.

Newbury, N. H., Sept. 10, 1894.

MY DEAR REID:

I got here a day or two ago after two months in the Rocky Mountains, which were to me exceedingly amusing and instructive. We were most of the time out of any possible communication with the world by mail or telegraph. We lived mostly on fish and game of our own purveying, and lived well. The régime grew intolerable after a while. I had not been able to send a line to my family nor get one from them from the 28th of July to the $3 \mathrm{~d}$ of September-the longest lacune of the sort in my history. We rode five hundred miles on horseback through trackless wildernesses, and felt as remote and friendless as $\mathrm{G}-\mathrm{C}-$ in Washington.

Of course, after having gone through all that without a sneeze, my first nights in a sleeping car gave me a hideous all-over cold from which I am only now beginning to pick up a little. 
HAY TO ADAMS.

\section{Newbury, N. H., Oct. 10, 1894.}

DEAR ADAMS:

Our house is dismantled-we are sitting among the ruins waiting for the train which is to take us to $\mathrm{C}$ - via $\mathrm{B}$ - The autumn has been very gorgeous, and to-day, for the first time, the wind and rain are stripping the trees of their goodly raiment, as if they were Viceroys who had lost a battle.

We had K- here for one day, and then, of course, a telegram came, clamoring for him to go to New York to see an exigent millionaire. He was in fine form, cheerier than I have seen him for several years,-full of schemes, all of them brilliant, not to say iridescent, in promise. I was glad to see him hopeful again, with, or without, reason.

....We shall be in Cleveland perhaps a month. I shall put in as much time in the marsh as I can. I see it is not possible to get to W- so soon as I had hoped. But it makes little difference where I am. I am old and inert and worthless. I have no heart to work, and, worse still, I have 
attained to the miserable knowledge that the work is not worth doing even if I could do it. But why all this dismal buzz?

HAY TO WHITELAW REID.

Cleveland, O., Oct. 26, 1894.

MY DEAR REID :

The Bishop and I had a pleasant journey together as far as Stamford. He did not seem much excited by the discovery that $\mathrm{K} \longrightarrow$, in eloping with Mrs. P_ had stolen the episcopal wardrobe. I do not doubt he found other vestments at $\mathrm{H}-$, and officiated with his usual grace and dignity. I found $\mathrm{D}-$ just starting for his foot-ball practice hour, and went along to the playing fields myself. My paternal heart was torn with anguish at seeing my first-born son rolled and tumbled and pulverized until he became a sorry spectacle of dirt and misery. Boss $\mathrm{H}-$, son of the Senator from $\mathrm{M}-$, was in the same eleven, and being of a pale complexion showed the strains of battle even worse than $\mathrm{D}$ - I stayed till the end, and then, 
thankful that they were all yet alive, I went back to New York, dined with $\mathrm{K}-$ at the $\mathrm{M}-$ Club, whose splendors made me open my rural eyes. It is certainly the finest Club in the world.

$\mathrm{O}-\mathrm{M}-$ came in and we spent the evening in gossip. The next day was one of the vilest I ever spent in New York. It was too atrocious for shopping or visiting, so I sat by the fire and dozed till my train went.

I find everyone well and flourishing. . . . I am glad I could go to you, and see you and Mrs. $\mathrm{R}$ - once more in the beautiful and appropriate setting of Ophir Farm. I will think of you on the $3 \mathrm{~d}$ sailing for the land of mystery and magic. I wish I could be with you. I begin to doubt if I shall ever see the Morgenland. ....

HAY TO ADAMS.

Cleveland, O., Oct. 27, 1894.

DEAR TAURA:

I think you owe me a letter. At least, on general principles, the man who has something to say owes a letter to the man who has not. This letter is merely a dun. 
I fly to my marsh Monday, to be gone a week or two, till the strife of tongues is over, till $\mathrm{T}$ - J-ceases from troubling and $\mathrm{M}-$ is at rest. I have never known a more gabby campaign. Eloquence overflows the legitimate stump and slops the sidewalk. I stop sometimes and listen to the gutter Ciceros. They are talking finances to the best of their little lungs. Free trade and single-tax have the call. J- seems to have hired dirty orators by the dozens to blather on street corners. Most of the working men are idle, so that there is always an audience. $\mathrm{He}$ is an amusing caricature of the classic demagogue with a dash of $\mathrm{T}$ - cynicism. . . . . If I had the bounding youth and literary vitality of a Tahiti chief, I would make a story about him, and get back the money I blow in, every two years, in vain, against him.

I went to see $\mathrm{R}$ — the other day to say goodbye before he sails for Algiers. $\mathrm{He}$ is in the evil case, I fear-though a momentary improvement just now has cheered up his wife and himself. $\mathrm{K}$ - and Bishop $\mathrm{P}$ - were of the party, so we were very gay and worldly. $\mathrm{P}-$ and I went off together, as he was going to $\mathrm{H}-$ and $\mathrm{I}$ to $\mathrm{N}-\mathrm{H}-$, and when we got to our station 
(Rye), we found that $\mathrm{K}$ - had not only eloped to White Plains with Mrs. P-, but had also carried off the Episcopalian trunk, with all the robes, chasubles and stoles which were to dazzle the $\mathrm{H} \longrightarrow$ faithful.

I found $\mathrm{D}$ - on the playing fields of Yale, engaged in deadly combat, with a face blackened with dirt and toil, and tangled hair, and garments ragged with onset. He seems to be in good enough shape, though mathematics make life as gloomy to him as it was to me, for the same cause.

I was much gratified at $\mathrm{K} \longrightarrow$ 's condition. $\mathrm{He}$ is quite in his old form, and up to his eyes in work, which will, of course, amount to nothing, but will keep him amused, which is the main thing.

HAY TO ADAMS.

New York, Dec. 2, 1894.

MY DEAR MONTAÑERO :

I sent a telegram of farewell to you at the $\mathrm{K}$ - before leaving Cleveland, and on arriving here found it in the rack-and so concluded you had flitted without patronizing your Club. But last night at the $\mathrm{C} \longrightarrow \mathrm{Club} \mathrm{I}$ met $\mathrm{K}-$, who 
told me you had not yet gone, but were going to-morrow. And I, who arrive at your door to-morrow evening! Evangeline was a joke to it.

But I have supped so full of sorrow that one more or less don't count. Are you ever coming back? Is this your final break for the year? Write me something of your itinerary, so that I may know under what star you are wandering at any given time. . . .

\section{HAY TO BURLINGAME.}

Washington, D. C., Dec. 4, 1894.

MY DEAR BURLINGAME :

It is utterly inexcusable of me not to have answered your kind letter of September 24th sooner. I have been living in sleeping cars most of the time, it is true, but, in the words of the music-hall ditty, "If I were in far Siam, I might have sent a telegram." The reason I did not answer it at once is that I dallied with the notion-it was very agreeable to me. But it is no use. I am too old. I can nevermore write anything, as a matter of enjoyment. I have not the critical faculty and-lots of other things I 
lack, which it would be painful for me to write and tedious for you to read. I may as well stop short and say I am very sorry I can't do it. $\mathrm{I}$ regret this all the more as $\mathrm{I}$ agree with you perfectly about Harte's present form. He was never better, his art is finer than ever, and his invention equally active and fertile, his coloring as sure and as vivid as when he wrote his first stories. "Cressy," "A Waif of the Plains," "Snowbound at Eagle's"-I would simply make a catalogue of his late stories, if began to say which I particularly like.

Yours, sad and sorry about it.

(Signed).

$\mathrm{C}-\mathrm{K}-$ would do it beautifully if you could eatch him and nail him to it.

HAY TO DR. CHAS. WALDSTEIN.

Washington, D. C., Dec. 7, 1894. MY DEAR WALDSTEIN :

You have doubtless forgotten the promise I made you to send you a copy of the special little edition of my verses. It has been a long 
time since then, but I have never visited Washington since I parted with you until to-day. Immediately on my arrival on this side I was seized by $\mathrm{H}-\mathrm{A}-$ and taken to the Rocky Mountains, where in the solitude of the Snake River and Teton country, we passed the summer. We had a delightful journey. I was for the first time in my life, two months without a letter or paper or telegram. The world and all its afiairs gradually died away from our minds-nothing was of interest but the day's trail and the night's camp. When we came out the world was very little changed, thirteen of my friends had died, among them A—s' brother, J- Q - But I am at the age when one's friends die every day (that sounds like B_'s "Cosmetic" article), and as my family were spared, my most anxious fears were quieted. My boy has entered Yale and was on the Freshman foot-ball team till a fever put him off. As the fever was a mild one, I can hardly regret the affliction which kept him out of the bloody Yale-Harvard battles of the year.

We are not yet settled in our house. Mrs. $\mathrm{H}$ - will arrive to-night and my daughter the next day. Everybody says, with the singular 
prescience that women have of social weather, that this is to be one of the dullest seasons ever known in Washington. All the better-my wife will not be danced into rags.

When Mrs. H- arrives she will say, did you send my regards to Dr. W- and I will say "yes."

Yours faithfully.

\title{
HAY TO ADAMS.
}

\author{
800 Sixteenth Street, \\ Lafayette Square, Jan. 14, 1895.
}

BELOVED, THOUGH ERRING:

I got your letter from I-, in which you promised me an address but gave none. Since then $I$ have seen $B-$, who tells me the name of your $\mathrm{H} \longrightarrow$ bankers.

I am so dazzled by the description of your leather bravery, that I have not the nerve to cuss you as you deserve for the way you have treated me. Think of yourself pulling out of the Washington Station at the very instant when I was coming in. If you have any conscience left, you 
will not be able to look an honest fer-de-lance in the face.

My season, thus inauspiciously begun, has continued on much the same note. $\mathrm{H}-$ - seems to have a good deal of fun. There is a good deal of dining and dancing. I hear no scandals; perhaps my ears are like T- B-'s, attuned to loftier symphonies, and so hear nothing going on about me. There must be scandal, of course, for there is the usual number of middle-aged belles and mashers drifting about. I dined the other night at Mrs. _-'s. She wore her new coronet-a closed one, if you please, with a royal Spanish provenance. Mrs. — was there, seated next to $\mathrm{N}$ - W- who, having nothing else on his mind, and feeling comfortable over his reëlection, entered upon a grave defence and eulogy of wifebeating. Mrs. - whose sense of humor is imperfect, was in a state of purple and screaming horror, which the grave L- promoted by a mild acquiescence in W-'s theory. She did not get over it all the evening, but went yelping about the drawing-room that "the man's a brute."

$$
\mathrm{J}-\mathrm{J}-\text { and } \mathrm{F}-\mathrm{W}-\text { are here. }
$$

They lunched with me at the Club the other day. Your neighbor $\mathrm{L}-, \mathrm{T}-\mathrm{R}-, \mathrm{L} \longrightarrow$, etc., 
were there. Weren't we nice and congruous! Then L_ had a party for J-. The dear old fellow is getting old and his memory for names is failing. — was there; and after Jhad told an anecdote about Nelson and Lord Macaulay, the accurate — yelled from the other side of the table, "Nonsense! Nelson died when Macaulay was six years old!" which added materially to old Joe's happiness.

I see nothing of nobody, so can tell you no news. Billy $\mathrm{H} \longrightarrow$ has come and gone. He wrote to "Dock" that our shacks laid over his in some respects, but that his didn't use so much coal. The $\mathrm{B}-$ mansion is rapidly coming down. I have not seen the $\mathrm{C} \longrightarrow \mathrm{s}$ to talk with them, but $I$ hear they take it philosophically. To Miss B-, condoling, Mrs. C- said :- "It won't be worse than living next door to you. You had so many balls and parties that you drove Mr. A- to Mexico to get a nap."

Mrs. A- has been here, much dined and supped by the nobility and gentry. I did not see her. S- is in New York, but does not come here, I believe. I have ceased to exist, socially and every other way-and it is all your fault. I 
find no one cares to know me except as a means to your breakfast-table.

L- says they had an uproarious time Twelfth Night at the Century. $\mathrm{K}$ - came as a bull-fighter; $\mathrm{H}-\mathrm{S}-$ as Svengali, and $\mathrm{W}-\mathrm{D}-$ as Trilby in a No. 18 shoe.

We have had a cold snap; the mercury dropped from $45^{\circ}$ to $5^{\circ}$ yesterday, but to-day is bright and not very cold.

This letter is nothing worth, except to give you renewed assurance of my love.

There were thirty-four Yale boys here for Christmas, and a dinner and dance every night somewhere or other for them. D- $\mathrm{R}-$ $\mathrm{H}-$ and $\mathrm{E}-\mathrm{H}-$ were the mashers most in evidence. "Spring it is cheery, Age it is dreary, What can an old man do but die?"

HAY TO WHITELAW REID.

Washington, D. C., Jan. 28, 1895.

MY DEAR REID :

I am glad to hear, not only from various paragraphs in the papers but also directly from 
$\mathrm{N}-$, that you are much better for your journey and on the high road to your habitual good health. I need not say how delighted Mrs. H- and I are to hear such cheering news of you.

It was very kind of Mrs. R- to remember $\mathrm{H}-$ and send her and me a card for the Patriarchs. But when the time came we were unable to go.

The social season here-which everybody told me was going to be the most lifeless and tiresome on record-turns out to be very amusing and quite crowded with things for the young people. People get into the habit of saying there are no men in the place because some man they are interested in is away. But there seems to be plenty of material for dances and dinners, and $\mathrm{H}$ - has all the frisking that is good for her. Mrs. $\mathrm{H}-$ and she have gone to New York to-day for a pleasant little visit with a dentist, and I am a forlorn grass-widower; all the more forlorn that $\mathrm{A}-$ is sailing about the Carribean Sea and is to be gone all winter. But it makes little difference whether I am amused or not, and the town from my windows seems gay. Mrs. C_ is gradually coming out of her mourning and is eagerly competed for at "little 
parties of six" where she is the gayest of the gay. The $\mathrm{W} \longrightarrow \mathrm{s}$ have taken a nice house in Street, where Mrs. W__ is much at home about tea time. She looks stronger and prettier than I have ever seen her and behaves herself beautifully. So does Mrs. C. L- who stays at home Thursdays like other Senatresses and returns her calls with animate punctuality. $\mathrm{C}$ - himself is very happy, having had a chance to "speak his mind" about G_— in the Senate last Saturday and having taken full advantage of the opportunity. The - had the incredible folly of accusing him of being bribed by $\mathrm{H} \longrightarrow$ 's friends to oppose the President's $\mathrm{H} \longrightarrow$ policy, and $\mathrm{C} \longrightarrow$ had a delightful ten minutes' fun telling the Senate and the country just how many kinds of a brass-riveted liar $\mathrm{G}$ - is.

I want to make an impression on your mind that Washington is a nice place to pass the winter in. There are three or four big new houses in full blast. B-'s is as lively as ever. Mrs. L-_'s new palace is always alive with merriment, and is really one of the most convenient and admirable houses for entertaining in a large way $I$ have ever seen. I heard the $B \longrightarrow$ s have 
just finished an enormous house, where they are going to be very gay. We have very few scandals to offer you. Mrs. __ and Mrs. _who last year were pulling caps about —-, have this year resumed that pleasing occupation over a stalwart young Briton named - These elderly flirtations are very funny; $\mathrm{M}$-- calls them the "roaring forties." But otherwise we are of a discretion which is most edifying. Mrs. - is mashing the diplomats one by onebut hates the town like pizen and is preparing for an early fiight.

Give our loves to Mrs. R-

Yours.

HAY TO ADAMS.

Washington, Feb. 6, 1895.

Not that I have anything to say-not that I even expect you will ever get this letter-do I write; but merely to send you affectionate greetings, and to say you are still remembered more kindly than you deserve in this good town you have so heartlessly deserted-this, I say, is to ease my own heart, and with no ulterior purpose. 
To be entirely candid I shall have to admit you do well to be absent. In the first place, the town is hopelessly dull, and in the second, the weather is detestable. I have never known it so persistently cold since that memorable winter of 1880 . It is past a joke. Our poor are dying like flies. In the smart world, all the efforts of your neighbors $\mathrm{B}-$ and $\mathrm{L}-$ cannot keep things alive. Mrs. C- amuses herself with her house, and $\mathrm{D}$ — in hurling anathemas at the gold-bugs in the style of a Hebrew prophet, but the most of us have not these advantages. Mrs. L- has gone to Boston to worship her granddaughter. My little $\mathrm{H}-$ is in New York, frisking with some of her schoolmates. . . . .

Your party wallows still in the trough of the sea. C_-'s recommendations to Congress are like wisdom crying in the streets-no man regardeth him. My party is nearly as much embarrassed by its victory as is yours by its defeat. Here the $\mathrm{R}-$ men are worse afraid of $\mathrm{McK}$ - than of the devil, and more anxious to beat him. In New York the good people are scared out of their wits for fear $\mathrm{P}$ - should do something they would like, so that they never make up their mind till he moves, and then they 
jump like sheep for the other thing. T- will come back in a year or two with an outfit of sevenfold deviltry. $\mathrm{D}$ - is quite nervous about $\mathrm{P}$ _ ; he thinks there is a chance of losing the State, in spite of its quarter-million majority. So you may be ready for another big swing of the pendulum.

Everybody seems to admit there will be no financial legislation this session. Perhaps $\mathrm{C}-$ will call an extra session-but I doubt it. They can rub along through summer with one or two loans.

$\mathrm{K}$ - is on the Slope-to be gone all the winter, spite of his doctors, who said he must go south or croak.

\section{HAY TO BURLINGAME.}

\section{Washington, D. C., April 10, 1895.}

DEAR BURLINGAME:

My daughter has written a few things that seem to my not impartial taste good enough to print. I send you a sonnet, knowing your conscience is more powerful with you than your friendship- 
and that, if you do not like it, you will not hesitate to send it back to me.

Yours sincerely.

\section{HAY TO BURLINGAME.}

\section{Sixteenth Street, Lafayette Square, May 2, 1895.}

DEAR BURLINGAME:

My little girl was made very happy by your letter this morning. Send the sonnet to me and she will correct the line you refer to. Thanking you most cordially for the interest you have taken in the matter, I am,

Yours sincerely.

HAY TO WHITELAW REID.

$$
\begin{gathered}
\text { Lafayette Square, } \\
\text { Washington, D. C., June 9, } 1895 .
\end{gathered}
$$

MY DEAR REID :

I sent you a telegram this morning of welcome home, hoping to see you in New York on Tuesday, and now I have a despatch from $\mathrm{N}-$ $23^{2}$ 
telling me of the sad errand which has called you West immediately on your landing. I have lost my own dear old mother so recently that I know how to sympathize with you. My mother, like yours, had lived to a great age, and there was little of pleasure left for her in life, yet the pang of parting was no less keen for that-the sense of irrevocable loss was something beyond reason or logic.

I sincerely hope this unexpected and painful journey will not impair your own restored health, through fatigue and emotion. Our hearts have followed you through your long journey, and we have rejoiced to know you were returning with renewed strength and capacity for work and enjoyment. We trust there will be no interruption of your convalescence.

We shall be established in our summer shanty at Newbury, New Hampshire, by the time you read this letter. . . .

HAY TO ADAMS.

Newbury, N. H., June 14, 1895.

To the most excellent Taura Atua, Chief of Amo, in his palace in the City of George the 
Truth Teller, these words, greeting, from his grovelling slave, unworthiest of his vassals, Jock, the Tenderfoot:-

I reached New York without incident, and saw $\mathrm{K}$ - , who was too busy to talk to me much, being engaged in the same futile pursuit of elusive wealth which has been for years so distressing a sight for his friends. He admitted he had made nothing but his expenses in the long and dismal winter's work in Oregon and Washington, but still hopes something might come of it. ... $\mathrm{He}$ has written another appalling bit of physics for the Journal of Science, which he says lays over the "Age of the World," out of sight; and still believes he will write the Magnum Opus if he can make money enough to be idle three years.

We had an uneventful journey up here, $\mathrm{H}-$ and I, and found the rest of the family on the railway platform, with a fresh and cultivated air of Boston about them. Our sky and air leave nothing to be desired, but I foresee that I shall miss your afternoon visit, and shall go sadly estray without your words of wisdom.

.... What a dull old man I am! I even lack words to tell you how I miss you. 


\section{HAY TO ADAMS.}

\section{Newbury, N. H., June 27, 1895.}

\section{MY DEAR TAURA :}

I am in the place wo nichts geschehe, the ultimate corner of the world. So I have no news for you, and only write to bid you farewell, to wish you everything good, and some things amusing.

The house is unusually still to-day, as $\mathrm{D}$ went off to the boat-race this morning, carrying with him a houseful of Yale boys who have been here for a week. I shuddered at their coming, not knowing how to entertain them,-but soon found they were utterly unconscious of my existence, and amused themselves together as well as a half dozen young puppies in a basket.

What a good time $\mathrm{T}$ - had in Boston! There is an idea for you! Why don't you go to your Class-anniversaries and get lionized and hand-shook and interviewed! I know why $I$ don't,-because I am an ass, and a dégénéré, whose initiative is dead.

Well, go your ways, have a good time on sea and land. My wife has just received a letter from Lady $\mathrm{C} \longrightarrow$, saying they are established 
in $\mathrm{R}$-, with a bachelor room for you, and already looking forward to the pleasure of seeing you. And I suppose the papers to-day will tell us of $\mathrm{M}-\mathrm{V}-$ 's added greatness. It is curious what a step $\mathrm{C}-$ made in marrying. Last year he was never thought of for Cabinet rank-now it is a matter of course. All Efeels that in marrying an heiress, he has merited well of the Patrie.

The whole house sends love and good wishes to you-it is raining outside and we have a bright fire blazing in the room. Ctoasting their brains on the hearth-rug. My wife is embroidering. $\mathrm{H}-$ and $\mathrm{A}-$ are making a futile song at the piano, which they will never have the energy to write and score,-and I am, so far as so venerable an impostor can be anything,

Yours affectionately.

HAY TO WHITELAW REID.

Newbury, N. H., July 21, 1895. MY DEAR REID :

I wrote to you last month addressing my letter to the $T$ - but have received no answer. 
Perhaps it did not reach you,-perhaps, as it was at the time of your mother's death, it was laid aside. In either case $I$ do not want to go through the summer without hearing from you. So I write again, though I have little to say except to ask how you are. I am living in the Place-WhereNothing-Happens. It would be difficult to imagine a life more stagnant than we lead in this rocky solitude. I am becoming so inert and worthless I shall soon not be worth knocking on the head.

The children run away from time to time and seek rest and recreation in livelier places. Aand $\mathrm{H}-$ are both visiting friends in Maine. D- has just been to Narragansett, where he saw Mr. H-, and reports him very weak but considerably improved. $\mathrm{He}$ has had a terrible battle for life.

Tell me how you are. A few words to your typewriter will not make much demand on your gray matter. I hope you have kept all you gained abroad, and added to it, so that you will be in condition for the fight next year.

I only read the $T-$, and so never see any personal news of you. Where are you? What are you about? What are your plans for the Summer and Fall? How is your health? How 
did you find the children? Is Ophir Farm increasing every moment in beauty and charm? (To be continued). . . .

\section{HAY TO WHITELAW REID.}

Newbury, N. H., August 4, 1895.

MY DEAR REID :

....We are living a curious vegetable life here. It suits elderly folks like Mrs. H- and me very well. I am afraid my children are getting old enough to kick at the solitude, but they are kept more or less contented by relays of their friends. I listen to their clamor, and reflect that, after all, the world is still young. But I am sure that you and I were never so young as the boys of to-day. The riddle of the painful world suggested itself to us earlier and more imperatively. The fellows who came of age in the Lincoln year were forced to look at life in wider aspects than the Sophomores of to-day.

I feel as though I should not look at anything much longer. I am getting a very bad pair of eyes on me. That is another reason for wanting to see you before the curtain drops. 
It really looks as if $\mathrm{H}-$ were getting well. He had two attacks of grippe in rapid succession, attacking the throat, lungs and heart at once, with a racking rheumatism thrown in. For many weeks he thought each day would be his last; but he stood the trip to $\mathrm{N}$ - very well, and my boy $\mathrm{D}$ - , who saw him there the other day, said he looked and talked like a man in convalescence. $\mathrm{He}$ is a valuable man, and I should hate to see him disappear from our public life. . . . .

HAY TO ADAMS.

Newbury, N. H., Sept. 3, 1895.

QUERIDO DE MI ALMA:

It is beyond belief that a fortnight has gone by since I received your valued favor from $\mathrm{T}-$, and now Mrs. H-C has a letter from Lady $\mathrm{C}$ - expressing her profound pleasure and gratitude in your visit. But time goes by imperceptibly in indolence and solitude, and there is nothing to do, or think, or write about. I have developed two or three more mortal diseases since I came here, and I am going to New York next 
week for vivisection. "But this is not journalism" as — would say.

I have a letter from $\mathrm{W}-\mathrm{R}-$ which is far from gay. $\mathrm{He}$ is ordered to $\mathrm{T}$ - for the winter, which has to me the sound of the glas funèbre. I am going to see him, for he has his moribunditude cheerful, and does not worry his friends except by his wheezing, and his pathetic attempt to talk jauntily of next year. And yet he may hold the cords at my funeral; for did I not sit, with profound emotion at the death-bed of $\mathrm{L}-\mathrm{P}-\mathrm{M}-$, and is he not-at the hour which is-all sorts of potentates and possibilities? There is nothing like being given up by the Doctors. It is a certificate of longevity.

Speaking of longevity, $\mathrm{K}$ - was coming here, but sent instead a long telegram from C$\mathrm{B}-$, at a ruinous expense, telling me he had to go out to the Coast-and would write. $\mathrm{He}$ might have written at an expense of two cents, and made me much more satisfied. But that would have been too simple a procedure. Nothing more has been heard of him-he has vanished into space. . . . .

And $\mathrm{B}-\mathrm{F}-$ has just left us on his way to Kipling. He has been spending his exiguous 
holiday among the Bluenoses and had good fishing with $\mathrm{G}-\mathrm{K} \longrightarrow$ at Cape Breton. He was gay and jimp, and lost very few things on our mountain, and most of those he found in his other coat. He was a brilliant feature in our otherwise dull landscape, in his stockings and knickers, and a radical red sash around his youthful waist. Mrs. S__ admired him very much but could hardly make up her mind whether he was a serious pirate or merely a Jesuit in disguise. He gave it as his deliberate opinion that this air would be a good thing for you, my cherished Taura! and I believe it might, if it were not for the mortal dulness I am conscious of diffusing about me.

If you don't hurry back, there won't be a silver man in America except you and $\mathrm{P}-$, and even $\mathrm{P}-$ said in an interview the other day that the jig was up. I think $\mathrm{R}-$ and $\mathrm{McK}-$ and $\mathrm{A} \longrightarrow$ and $\mathrm{H} \longrightarrow$ and $\mathrm{M} \longrightarrow$ are all good goldbugs now. A large majority of Democrats have thought they were not, but the post-masters and "Deppity Marshals" have convinced them that they are,-at least, such of them as go to Conventions.

Poor $\mathrm{D} \longrightarrow$ de $\mathrm{L}-$ is becoming the target of our unbridled and licentious press, because he 
tries to serve his country, and wants ours to obey the laws. The Cubans are knocking $\mathrm{C}$ - about like old boots, and Yellow Jack is joining in the fun as merrily as he knows how. You will have a fine chance in Spain to make a revolution, for the whole army will be in the ever-faithful Isle by the time you get there.

.... I hear $\mathrm{H}$ — is making steady though slow improvement. He walks a little and drives out every day. D_, who has been there, says he is as bright in talk as ever, and considers himself on the road to health. I heard of young $\mathrm{D}$ _ saying the other day that his father was to have the choice of the $\mathrm{W}$ - and $\mathrm{M}$ - or the $\mathrm{E}-\mathrm{M}-$. And election is a year off.

Good-bye! Be happy! Give our loves to your amiable compagnons de voyage. And come back, not too late, to the land which can afford you more politics and more subjects of luxurious scorn than any other. 
HAY TO WHITELAW REID.

Newbury, N. H., Sept. 5, 1895.

MY DEAR REID :

... The summer is ending here in great beauty. The only fault we can find is the scarcity of rain, which is drying up our springs and reducing our brooks to a mere trickle over the rocks. We have had two young artists here, $\mathrm{H}-\mathrm{N}-$ and $\mathrm{G}-\mathrm{H}-$ - They both enjoyed our woods and hills, and painted furiously from dawn till sunset.

I have no news of the gay world, or the world of politics except what the $T$ - tells me. But what a mess our friends the enemy are getting themselves into! Led by A- into the silver camp in Illinois, and by B- into the "goldbug conspiracy" in $\mathrm{O}-$, and in $\mathrm{K}$ - torn in pieces by the most grotesque straddle ever seen in politics. But none of these things move the true $\mathrm{M}-\mathrm{H}-\mathrm{W}-$ chortled with joy over the $\mathrm{K}$ Convention; it was so wise and noble a stand for principle. . . . 
HAY TO ADAMS.

Newbury, N. H., Sept. 20, 1895.

Your letter from Paris of the 7th has just got here, after I know not what philandering on the way. Meanwhile you should have received two letters from me, with nothing in them, but at least showing that you inhabited my thoughts. I write in a hurry this morning to try to catch to-morrow's steamer to send you one more greeting before you sail for home.

To judge from your last letter, you are doing pretty well. Your Normandy experiences, objective and subjective, seem all that could have been desired. You fill me as you often do, with a feeble impulse of travel. I have never seen Normandy and I feel a sense of deprivation in reading your letter. But to enjoy it as you did, one should carry more baggage in one's skull than I do. I have ceased to read, write or think-fallen into second childishness and mere oblivion.

Rudyard Kipling has been here for a day or two. How a man can keep up so intense an intellectual life without going to Bedlam is amazing. He rattled off the frame-work of about 
forty stories while he was with us. One day I was, as an ignorant layman will, abusing the sun-myths, and happened to say I expected to see "Mary had a little lamb" become one. $\mathrm{He}$ instantly jumped upon it, and as fast as his tongue could wag, he elaborated the myth. It was better than anything $\mathrm{A}-\mathrm{L}-$ ever wrote. $\mathrm{He}$ was very bright and pleasant, entertained himself and all the rest of us, and made $\mathrm{C}-$ very happy.

Of course in the wilderness I have no news. Mrs. C - after almost promising to come here has failed us, and we have been unable to go there. But we hear she is happy and beautiful-and so are content. Miss L- has married her Duke and Miss W- her $\mathrm{K}-$, after so many denials. I am to see $\mathrm{R}-$ on the 1st prox. and have some talk. He has been improving somewhat this summer in the Adirondacks and seems not at all despondent. But he is the cheeriest optimist I ever knew, and will be so till the end.

I fear we shall have gone west before you arrive. But if so, I shall see you in November. Our loves to the $\mathrm{L} \longrightarrow \mathrm{S}$. 
HAY TO ADAMS.

Port Clinton, O., Oct. 25, 1895.

DEARLY BELOVED :

Would I were with thee, wherever thou art!

This last fortnight has been the longest of my life. I have visited $\mathrm{B}-, \mathrm{N}-\mathrm{Y} \longrightarrow$, $\mathrm{W} \longrightarrow \mathrm{P} \longrightarrow, \mathrm{C}-, \mathrm{W}-$ and $\mathrm{S} \longrightarrow$, and now, for my sins, am stranded on this arid promontory of Winou his point, unwilling to go until I have shot a duck or two, and yet conscious that ducks there are none and never will be until we have a nor'east storm, and the Lake rises, and the marsh fills with water, and the carp stop grubbing up the celery and the spongemoss, and the canvas-backs hear of it and come back to their ancient love.

But you have seen my wife, since I have, $O$ nimium fortunatus, and know of all our planswhich are little worth except that they bring us to Washington and you, in about three weeks. Until then my life drags on with a broken wing.

I have seen some politicians and talked some politics since I wrote you last. I will tell you some things too tedious to write, when we meet, 
but, in substance, I think McK- is much "forrider" than a few months ago. The faithful think $\mathrm{F}$ is pulling straight, and there are anguilles sous roche that betoken an early collapse of other booms.

My wife has told you of $\mathrm{R}-$; of his slow gain and his renewed hopes-but Arizona has to me a mournful sound. 



RETURN CIRCULATION DEPARTMENT

TO $\rightarrow 202$ Main Library

\begin{tabular}{l|l|l}
\hline $\begin{array}{l}\text { LOAN PERIOD 1 } \\
\text { HOME USE }\end{array}$ & 2 & 3 \\
\hline 4 & 5 & 6 \\
\hline
\end{tabular}

ALL BOOKS MAY BE RECALLED AFTER 7 DAYS

1. month loans may be renewed by calling 642.3405

6. month loans may be recharged by bringing books to Circulation Desk

Renewals and recharges may be made 4 days prior to due date

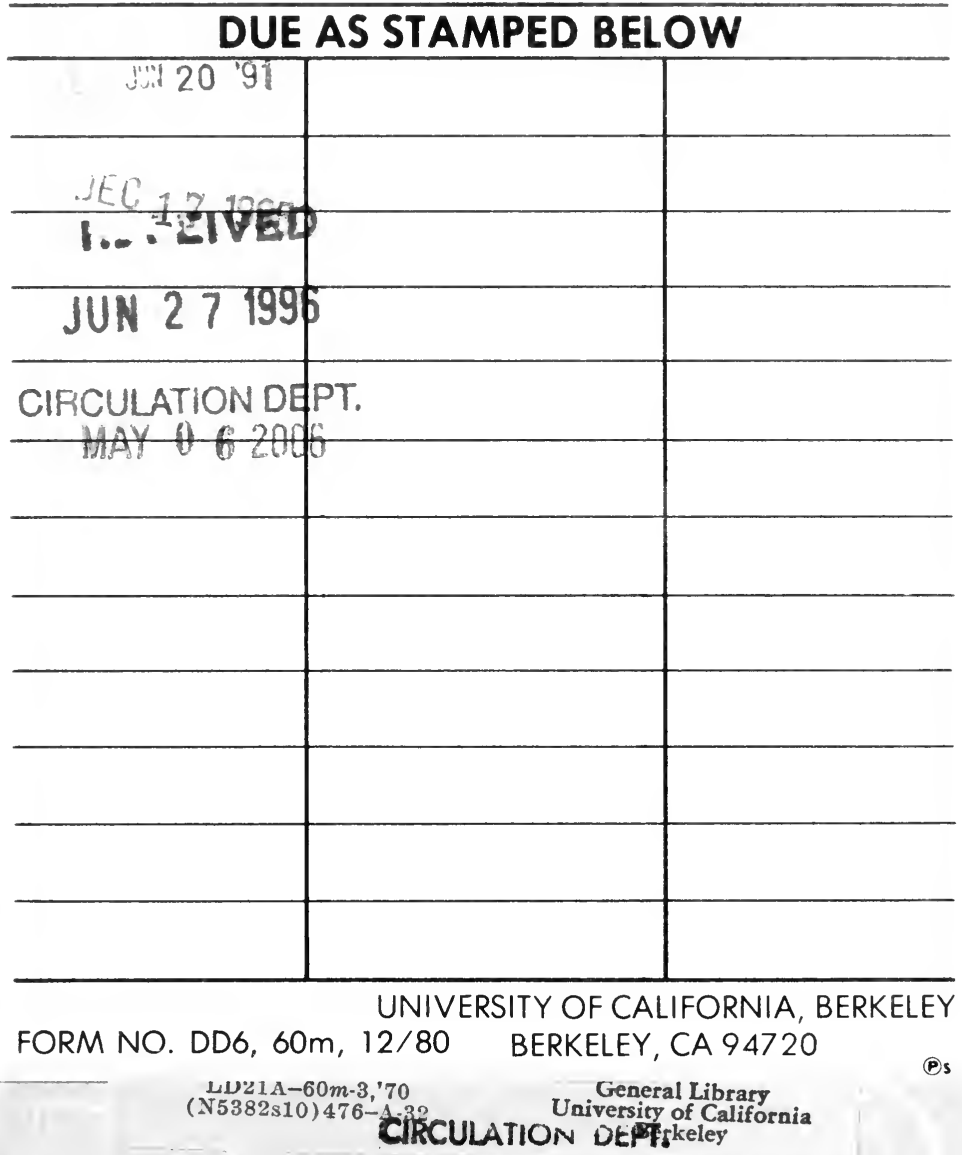


U.C. BERKELEY LIBRARIES

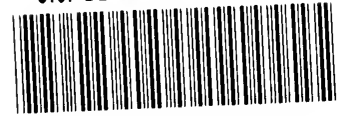

C035319514 
